\title{
ECONOMICS
}

\section{FOOD AND AGRICULTURAL PRICES ACROSS COUNTRIES AND THE LAW OF ONE PRICE}

by

Kenneth W Clements

Jiawei $\mathrm{Si}$

Long $\mathrm{H}$ Vo

Business School

University of Western Australia

DISCUSSION PAPER 17.04 


\title{
FOOD AND AGRICULTURAL PRICES ACROSS COUNTRIES AND THE LAW OF ONE PRICE*
}

\author{
by \\ Kenneth W Clements, Jiawei Si and Long H Vo \\ Business School \\ The University of Western Australia
}

\begin{abstract}
$\underline{\text { Abstract }}$
This paper investigates several basic characteristics of food and agricultural prices across commodities, countries and time. The first part of the paper uses consumer prices across commodities and countries from the International Comparisons Program and finds that food has a distinct tendency to be cheaper in rich countries as compared to poor ones. This possibly reflects the productivity bias effect of Balassa and Samuelson, or Engel's law. Food prices are also less dispersed in rich countries. Cross-country and cross-commodity tests reject the law of one price (LOP) more often than not with, as might be expected with consumer prices. In the second part of the paper, data on agricultural producer prices from the Food and Agriculture Organisation are used to test if deviations from the LOP are stationary, using a panel approach. As about three-quarters of the 100+ products obey the law, there seems to be some support for the LOP in this context.
\end{abstract}

\footnotetext{
${ }^{*}$ For providing us with unpublished data, we thank the World Bank. We also thank Aiden Depiazzi and Haiyan Liu for excellent research assistance. This research was financed in part by the ARC and BHP Billiton.
} 


\section{Introduction}

Over the longer term, productivity in agriculture has grown sufficiently to keep food prices from rising substantially, thus contributing to rising living standards. Whether or not this will continue in the future is subject to much debate and conjecture. ${ }^{1}$ But not only is the behavior of agricultural prices over time important for the evolution of living standards, so too is the distribution of these prices across countries: In the poorest countries, consumers spend, on average, one-half or more of their incomes on food, while in high-income countries food absorbs 10 percent or less. This is, of course, a manifestation of Engel's law. In this paper, we show that food becomes cheaper as we move from poor to rich countries, thus amplifying the Engel effect of the low (high) food share of the rich (poor) on their real incomes. Not only are food prices in rich countries lower, but so is the dispersion of the prices of individual food items, as we shall demonstrate.

There are at least three possible reasons for cheaper food in high-income countries. First, because of their superior endowment of agricultural land and favourable climate, these countries may simply have a comparative advantage in producing food at lower prices. More likely, however, is the productivity bias hypothesis of Balassa (1964) and Samuelson (1964). According to this hypothesis, due to their labour intensity and lack-of-commodification nature, services (read non-foods) are less amenable to productivity growth than other sectors (read food). In highproductivity, high-income countries, this leads to services being relatively more expensive, and food prices relatively lower.

A third explanation of lower food prices is Engel's law. Higher income is likely to lead to growth in the consumption of most goods, but because of Engel's law, food grows slower than average. If on the supply side all sectors (food and non-food) expand at approximately the same rate, at constant relative prices there is an excess supply of food. The end result is lower food prices in countries with higher incomes. In this paper we present a stylised model of this process in which prices depend on incomes.

When studying prices across countries, it is natural to inquire about the extent to which they differ. If when we convert to a common currency, the price of a product is equal in two countries, the price in terms of the domestic currency then responds one-for-one to exchange-rate changes, and currency values play no role in the structure of relative prices. This "law of one

\footnotetext{
1 See, for example, FAO (2016), OECD/FAO (2016) and USDA (2016).
} 
price" (LOP) is based on arbitrage -- the process of buying in the country where the product is cheap and selling where it is expensive will eliminate price differences. When prices are not equalised, prima facie there is a deadweight efficiency loss that could be eliminated by transferring the product from the low-cost location to where it is more highly valued. Of course, the LOP only holds under the stringent conditions of a product being identical in all aspects other than the currency in which it is denominated, and no barriers to trade. While these conditions are unlikely to hold in most cases, it is still of considerable interest to investigate how closely products come to satisfying the LOP. Closely related to the LOP is the purchasing power parity (PPP) hypothesis, according to which the value of the country's currency equals the ratio of some macroeconomic index of prices at home to that abroad. ${ }^{2}$

To investigate the link between prices and exchange rates, we move from food indexes across countries to something approaching the prices actually paid by consumers for a large number of goods in $150+$ countries. We estimate (i) a cross-country regression for the price of each good; and (ii) a cross-commodity regression for each country. These provide summary measures of the degree to which prices of each good in all countries, and the prices of all goods in each country, do/do not respond proportionately to exchange-rate changes. The LOP is rejected more often than not, but in many cases the violations did not seem particularly large.

In addition to food prices faced by consumers, we also analyse the prices of agricultural products received by producers. Using the large data set assembled by the Food and Agriculture Organisation (FAO, online), we again study the extent to which prices are equalised. These data also have a time dimension in addition to the product and country distinction, and so we are able to use panel-unit-root tests of the LOP to investigate whether deviations from the law are stationary. We find about three-quarters of the 100+ products obey the law. Although the results are subject to qualification, it still seems reasonable to conclude that there seems to be considerable support for the LOP.

\footnotetext{
${ }^{2}$ For a review of the LOP and its relation to PPP, see Marsh et al. (2012). On the basis of a substantial literature, Marsh et al. conclude that the evidence is not unanimous, but there is now increasing acceptance that the LOP and PPP hold as longer-run tendencies. In their words: "While it is fair to say that a universal consensus may not exist yet, the emerging consensus at the present time is converging toward the view that deviations from the LOP are transitory and therefore the LOP holds in the long run among a broad range of tradable goods and currencies" ( $p$. 213). They also state: "Overall, our reading of the literature suggests that PPP is a good first approximation to the long-run behaviour of exchange rates" (p. 203). For other reviews of PPP theory, see Dornbusch (1988), Frenkel (1978), Froot and Rogoff (1995), Manzur (2008), Officer (1982), Rogoff (1996) and Taylor and Taylor (2004).
} 
The next section of the paper presents indexes of food prices across countries from the International Comparisons Program (hereafter referred to as the "ICP") and establishes that they fall as income rises. Section 3 deals with the dispersion of food prices, while Section 4 presents the model of prices that depend on income. Next, the relationship between exchange rates and prices is analysed in Sections 5-7 -- some foundation material on the LOP in Section 5, applications to consumer prices in Sections 6 and 7 and to producer prices in Sections 8-10. Concluding comments are contained in Section 10.

\section{Eating, Drinking and Prices Across Countries}

Table 2.1 provides the starting point with basic data from the World Bank on the income per capita and food consumption and prices in 155 countries in 2011 , from the ICP. ${ }^{3}$ The countries range from the richest (such as the US, Norway and Switzerland) to the poorest (Comoros, Niger, Congo), with a ratio of incomes of the order of 100:1. There is also strong evidence of Engel's law as the share of total consumption devoted to food falls from more than 50 percent in the poorest countries to about 10 percent in the richest. This effect is particularly clear in Figure 2.1, a plot of the food shares in the 155 countries against incomes.

The ICP data divides GDP into 155 categories (called "basic headings"); the first 132 are items of consumption, of which the first 32 of these are food items, including alcoholic beverages. After minor adjustments (see Appendix), we are left with 31 food basic headings and 131 consumption basic headings. Define $\mathrm{w}_{\mathrm{i}}$ as the budget share of good $\mathrm{i}$ (the proportion of total consumption expenditure devoted to $\mathrm{i}$ ), so that the budget share of all food is $\mathrm{W}_{\mathrm{F}}=\sum_{\mathrm{i}=1}^{31} \mathrm{~W}_{\mathrm{i}}$. If $\mathrm{p}_{\mathrm{i}}$ is the price of category $i$, the relative price of food can be defined as

$$
\log \left(\frac{\mathrm{P}_{\mathrm{F}}}{\mathrm{P}}\right)=\log \mathrm{P}_{\mathrm{F}}-\log \mathrm{P}=\sum_{\mathrm{i}=1}^{31}\left(\frac{\mathrm{W}_{\mathrm{i}}}{\mathrm{W}_{\mathrm{F}}}\right) \log \mathrm{p}_{\mathrm{i}}-\sum_{\mathrm{i}=1}^{131} \mathrm{~W}_{\mathrm{i}} \log \mathrm{p}_{\mathrm{i}} .
$$

This relative price is the difference between the conditional budget-share weighted logarithmic mean of the prices of the food items, $\log \mathrm{P}_{\mathrm{F}}$ and the $\log$ of the cost-of-living index, $\log \mathrm{P}$. Table 2.1 contains, in columns 4 and 9, the food relative price (2.1), and there is a distinct tendency for food to become cheaper as income rises. For example, on average for the poorest quartile of countries, the relative price of food is 36.3 percent, while this falls to 13.7 for the richest quartile. This means that, on average, food is about 20 percent cheaper in the richest countries as

\footnotetext{
${ }^{3}$ The data source is World Bank (unpublished). For details of the data, see the Appendix.
} 
compared to the poorest. ${ }^{4}$ Panel A of Figure 2.2 plots food prices against income and the regression coefficient of $\log$ income is -6.18 and significant, implying that a 10-percent rise in income leads to food prices falling by about 6 percentage points. Panel B of this figure allows the regression line to vary across income quartiles; and as all four within-quartile slope coefficients are insignificant, the bulk of the decline in food prices must occur in moving from quartile to quartile.

As $\mathrm{W}_{\mathrm{F}}$ is the budget share of food, the share of non-food is $1-\mathrm{W}_{\mathrm{F}}$, while the share of non-food good $i$ in total non-food is $w_{i} /\left(1-W_{F}\right)$. An index of the cost of the $131-31=100$ nonfood items is then

$$
\log \mathrm{P}_{\mathrm{N}}=\sum_{\mathrm{i}=32}^{131}\left(\frac{\mathrm{w}_{\mathrm{i}}}{1-\mathrm{W}_{\mathrm{F}}}\right) \log \mathrm{p}_{\mathrm{i}},
$$

and the cost of living can be expressed as $\log \mathrm{P}=\mathrm{W}_{\mathrm{F}} \log \mathrm{P}_{\mathrm{F}}+\left(1-\mathrm{W}_{\mathrm{F}}\right) \log \mathrm{P}_{\mathrm{N}}$. The relative price of food (2.1) can be reformulated as $\log \mathrm{P}_{\mathrm{F}}-\log \mathrm{P}=\left(1-\mathrm{W}_{\mathrm{F}}\right)\left(\log \mathrm{P}_{\mathrm{F}}-\log \mathrm{P}_{\mathrm{N}}\right)$ so that

$$
\log \mathrm{P}_{\mathrm{F}}-\log \mathrm{P}_{\mathrm{N}}=\frac{1}{1-\mathrm{W}_{\mathrm{F}}}\left(\log \mathrm{P}_{\mathrm{F}}-\log \mathrm{P}\right)
$$

In words, the relative price of food in terms of non-food is a multiple $1 /\left(1-\mathrm{W}_{\mathrm{F}}\right)>1$ of index (2.1), the relative price of food in terms of all goods, food and non-food. Index (2.2) "strips out" the role of food prices in the deflator in index (2.1). For the top quartile countries where food accounts for roughly 10 percent of the budget, index (2.2) is about 10 percent more than (2.1). However, for the bottom quartile the share is closer to one half and index (2.2) is about twice as

\footnotetext{
${ }^{4}$ If the relative price of food in country $\mathrm{c}$ is $\mathrm{x}_{\mathrm{c}}$, then a representative basket of food costs $\exp \mathrm{x}_{\mathrm{c}} \approx 1+\mathrm{x}_{\mathrm{c}}$ times the cost of a representative basket of all goods, with $\mathrm{x}_{\mathrm{c}}=0$ for $\mathrm{c}=$ the US as a normalization. The relative cost of food in country $c$ as compared to that in another country $d$, where the relative price is $x_{d}$, is $\exp \left(\mathrm{x}_{\mathrm{c}}\right) / \exp \left(\mathrm{x}_{\mathrm{d}}\right)=\exp \left(\mathrm{x}_{\mathrm{c}}-\mathrm{x}_{\mathrm{d}}\right)$. For countries in the top and bottom income quartiles, the averages are $x_{c}=0.137$ and $x_{d}=0.363$; consequently, the cost difference is $\exp (0.137-0.363)=0.798$. Thus, food is 20.2 percent cheaper in the top quartile. Using the approximation that for small $z, \exp z \approx 1+z$, the approximate cost difference is $1+\left(x_{c}-x_{d}\right)=1+0.137-0.363=0.774$, implying that food is approximately 22.6 percentage cheaper. The approximation error is $22.6-20.2=2.4$ percentage points, which is not particularly small and reflects the large difference between the top and bottom quartiles.
} 
large as (2.1). Food in terms of non-food is about 44 percent cheaper in the richest countries as compared to the poorest. ${ }^{5}$

The conclusion of the above discussion is if we use the (2.2) measure, the relative price of food falls by much more as income rises. That is, the price of food in terms of non-food falls by more than that of food in terms of the cost-of-living (which includes the costs of food and non-food). This shows that the fall in the price of food is not an implication of Engel's law. To be sure, food is more heavily weighted in the cost-of-living index of poor countries, but when this is controlled for by index (2.2), food prices fall even faster as income rises.

\section{Price Dispersion}

For food item $\mathrm{i}, \mathrm{w}_{\mathrm{i}}$ is its share of total consumption expenditure and $\mathrm{w}_{\mathrm{i}} / \mathrm{W}_{\mathrm{F}}$ is its share within food, or the "conditional" share. For simplicity of notation, write the conditional share as $\mathrm{w}_{\mathrm{i}}^{\prime}=\mathrm{w}_{\mathrm{i}} / \mathrm{W}_{\mathrm{F}}$, with $\sum_{\mathrm{i}=1}^{31} \mathrm{w}_{\mathrm{i}}^{\prime}=1$, so that the index of food prices in equation (2.1) can then be written as $\log \mathrm{P}_{\mathrm{F}}=\sum_{\mathrm{i}=1}^{31} \mathrm{~W}_{\mathrm{i}}^{\prime} \log \mathrm{p}_{\mathrm{i}}$. The corresponding measure of dispersion of food prices is the weighted variance:

$$
\Pi_{\mathrm{F}}=\sum_{\mathrm{i}=1}^{31} \mathrm{w}_{\mathrm{i}}^{\prime}\left(\log \mathrm{p}_{\mathrm{i}}-\log \mathrm{P}_{\mathrm{F}}\right)^{2} .
$$

Table 2.1 gives in columns 5 and 10 the standard deviation of prices, $\sqrt{\Pi_{\mathrm{F}}}$, for each country. Figure 3.1 reveals the dispersion of prices falls significantly as income rises: But comparing Figures 2.1, 2.2 and 3.1, it can be seen that dispersion falls the fastest with income, then the budget share, and then the relative price.

What is the source of the price dispersion? Is it because of large differences in relative prices of the broad food groups (such as bread and cereals vs meats vs diary), or is it due to more micro differences between more closely related foods within the broad groups (such as rice vs

\footnotetext{
${ }^{5}$ As indicated in the previous footnote, on the basis of equation (2.1), the relative price of food in terms of all goods for the income top quartile is $\mathrm{x}_{\mathrm{c}}=0.137$, and $\mathrm{x}_{\mathrm{c}}=0.363$ for the bottom quartile. From Table 2.1, roughly speaking, on average countries in the top income quartile devote about 10 percent of the budget to food $\left(\mathrm{W}_{\mathrm{Fc}}\right)$, while in the bottom quartile, this is about 50 percent. Thus, using equation (2.2), in the top quartile the relative price of food in terms of non-food is $\mathrm{x}_{\mathrm{c}} /\left(1-\mathrm{W}_{\mathrm{Fc}}\right)=0.137 / 0.9=0.152$. For the bottom quartile, $\mathrm{x}_{\mathrm{d}} /\left(1-\mathrm{W}_{\mathrm{Fd}}\right)=0.363 / 0.5=0.726$. The ratio of costs is now $\exp \left[\mathrm{x}_{\mathrm{c}} /\left(1-\mathrm{W}_{\mathrm{Fc}}\right)\right] / \exp \left[\mathrm{x}_{\mathrm{d}} /\left(1-\mathrm{W}_{\mathrm{Fd}}\right)\right]=$ $\exp \left(\mathrm{x}_{\mathrm{c}}-\mathrm{x}_{\mathrm{d}}\right) \exp \left[\left(1-\mathrm{W}_{\mathrm{Fd}}\right) /\left(1-\mathrm{W}_{\mathrm{Fc}}\right)\right]$. For the two quartiles, this ratio is $\exp (0.152-0.726)=0.563$, so food is now about 44 percent cheaper in the top quartile.
} 
bread within the bread and cereals group)? Some light can be shed on this issue by aggregating the 31 food items into 7 broader groups as indicated in column 1 of Table 3.1. Denote these groups by $\mathbf{S}_{\mathrm{F}}^{1}, \ldots, \mathbf{S}_{\mathrm{F}}^{7}$ and define the share of total food expenditure allocated to group $g$ and the share of group expenditure devoted to $i \in \mathbf{S}_{\mathrm{F}}^{\mathrm{g}}$ as

$$
\mathrm{W}_{\mathrm{F}}^{\mathrm{g}}=\sum_{\mathrm{i} \in \mathrm{S}_{\mathrm{F}}^{\mathrm{g}}} \mathrm{w}_{\mathrm{i}}^{\prime}, \quad \overline{\mathrm{w}}_{\mathrm{i}}=\frac{\mathrm{w}_{\mathrm{i}}^{\prime}}{\mathrm{W}_{\mathrm{F}}^{\mathrm{g}}}, \quad \mathrm{i} \in \mathbf{S}_{\mathrm{F}}^{\mathrm{g}},
$$

so that $\sum_{\mathrm{g}=1}^{7} \mathrm{~W}_{\mathrm{F}}^{\mathrm{g}}=\sum_{\mathrm{i} \in \mathrm{S}_{\mathrm{F}}^{\mathrm{g}}} \overline{\mathrm{w}}_{\mathrm{i}}=1$. These budget shares are given in columns 2-6 of Table 3.1 for the income quartiles. These reveal considerable dispersion in spending patterns across the income distribution, especially for the bread and cereals group, where the share falls from 29 to 14 percent in going from the bottom to top quartile. The index of prices within group $g$ and the corresponding variance are

$$
\log \mathrm{P}_{\mathrm{F}}^{\mathrm{g}}=\sum_{\mathrm{i} \in \mathbf{S}_{\mathrm{F}}^{\mathrm{g}}} \overline{\mathrm{w}}_{\mathrm{i}} \log \mathrm{p}_{\mathrm{i}}, \quad \Pi_{\mathrm{F}}^{\mathrm{g}}=\sum_{\mathrm{i} \in \mathrm{S}_{\mathrm{F}}^{\mathrm{g}}} \overline{\mathrm{w}}_{\mathrm{i}}\left(\log \mathrm{p}_{\mathrm{i}}-\log \mathrm{P}_{\mathrm{F}}^{\mathrm{g}}\right)^{2} .
$$

Columns 7-11 of Table 3.1 contain the relative prices of the groups and the items within groups. In five of the seven cases, the relative prices of the groups fall as we move from the poorest to the richest countries.

With these groups, the price variance (3.1) can be decomposed into between- and withingroup components:

$$
\Pi_{\mathrm{F}}=\sum_{\mathrm{g}=1}^{7} \mathrm{~W}_{\mathrm{F}}^{\mathrm{g}}\left(\log \mathrm{P}_{\mathrm{F}}^{\mathrm{g}}-\log \mathrm{P}_{\mathrm{F}}\right)^{2}+\sum_{\mathrm{g}=1}^{7} \mathrm{~W}_{\mathrm{F}}^{\mathrm{g}} \Pi_{\mathrm{F}}^{\mathrm{g}} .
$$

The first term on the right-hand side is the between-group component of the total variance of food prices. This is a weighted variance of the prices of the groups, or a summary measure of the dispersion of relative prices of the groups. The second term is the within-group component, which is a weighted average of the variances within each of the 7 groups, $\Pi_{\mathrm{F}}^{\mathrm{g}}, \mathrm{g}=1, \ldots, 7$.

Table 3.2 contains decomposition (3.3) and shows in columns 3 and 4 that the withingroup variability of prices exceeds the between-group component by at least 40 percent. In other words, micro price differences are more important than those of the broad groups in accounting for the overall dispersion of food prices. From columns 5-11, the group variance for bread and cereals is the largest in all but the top quartile (where meat and seafood dominate). As the group variance $\Pi_{\mathrm{F}}^{\mathrm{g}}$ in (3.2) -- which measures the dispersion of prices of members of the group -- is 
independent of the size of the group, by itself the large share for bread and cereals for poorer countries does not account for the dominance of this group's $\Pi_{\mathrm{F}}^{\mathrm{g}}$. That is to say, the large value reflects only the large dispersion of relative prices within this group, not its size. However, the within-group component of the total variance, the last term on the right of (3.3), is $\sum_{\mathrm{g}=1}^{7} \mathrm{~W}_{\mathrm{F}}^{\mathrm{g}} \Pi_{\mathrm{F}}^{\mathrm{g}}$, which uses budget shares to weight the individual group variances. This means that for poorer countries, the large value of $\Pi_{\mathrm{F}}^{\mathrm{g}}$ for bread and cereals is magnified by the large weight it receives in $\Sigma_{\mathrm{g}=1}^{7} \mathrm{~W}_{\mathrm{F}}^{\mathrm{g}} \Pi_{\mathrm{F}}^{\mathrm{g}}$.

The conclusion is that the higher dispersion of prices in low-income countries can be attributed to (i) the larger variability of prices within the broad food groups, as opposed to that between groups; and (ii) the important role of prices within the bread and cereals group.

\section{A Model of Income-Dependent Prices}

In light of the above finding of the role of income in determining food prices, this section starts with a stylised model of this process. We then apply this model to the cross-country food prices. The first sub-section draws on Clements et al. (2013).

\section{A Stylised Model}

Let $q_{i}^{s}$ be the quantity of good $i$ supplied and $q_{i}^{d}$ be the corresponding quantity demanded. Let each of these quantities depend on the relative price of the good $\mathrm{p}_{\mathrm{i}} / \mathrm{P}$. Additionally, both the supply of and demand for the product are taken to depend on real income Q. Assuming log-linearity:

$$
\log q_{i}^{s}=\phi_{i}^{s}+\eta_{i}^{s}\left(\log p_{i}-\log P\right)+\theta_{i}^{s} \log Q, \quad \log q_{i}^{d}=\phi_{i}^{d}+\eta_{i}^{d}\left(\log p_{i}-\log P\right)+\theta_{i}^{d} \log Q,
$$

where $\phi_{i}^{\mathrm{s}}\left(\phi_{\mathrm{i}}^{\mathrm{d}}\right)$ is the intercept of the supply (demand) function; $\eta_{\mathrm{i}}^{\mathrm{s}}>0\left(\eta_{\mathrm{i}}^{\mathrm{d}}<0\right)$ is the price elasticity of supply (demand); and $\theta_{i}^{s}\left(\theta_{i}^{d}\right)$ is the income elasticity of supply (demand). The term $\mathrm{Q}$ in the demand function represents a conventional income effect. The appearance of $\mathrm{Q}$ in supply is less conventional and represents a "scale" variable measuring the tendency for a richer economy to produce more of the good (when $\left.\theta_{i}^{s}>0\right)$. Next, define $\alpha_{i}^{\prime}=\left(\phi_{i}^{d}-\phi_{i}^{s}\right) / \Delta_{i}$ and 
$\beta_{\mathrm{i}}^{\prime}=\left(\theta_{\mathrm{i}}^{\mathrm{d}}-\theta_{\mathrm{i}}^{\mathrm{s}}\right) / \Delta_{\mathrm{i}}$, where $\Delta_{\mathrm{i}}=\eta_{\mathrm{i}}^{\mathrm{s}}-\eta_{\mathrm{i}}^{\mathrm{d}}>0$ is the excess supply elasticity. Then, market clearing implies that $\log q_{i}^{s}=\log q_{i}^{d}$, or

(4.1) $\log \mathrm{p}_{\mathrm{i}}-\log \mathrm{P}=\alpha_{\mathrm{i}}^{\prime}+\beta_{\mathrm{i}}^{\prime} \log \mathrm{Q}$.

The additional requirement for general equilibrium for the economy as a whole is that if some relative prices increase, they must be balanced by others that decrease. This is clearest if we define the price level as a budget-share weighted average of the prices of the $\mathrm{n}$ goods, that is, $\log \mathrm{P}=\sum_{\mathrm{i}=1}^{\mathrm{n}} \mathrm{w}_{\mathrm{i}} \log \mathrm{p}_{\mathrm{i}}$. This implies $\sum_{\mathrm{i}=1}^{\mathrm{n}} \mathrm{w}_{\mathrm{i}}\left(\log \mathrm{p}_{\mathrm{i}}-\log \mathrm{P}\right)=0$, or that that weighted average of the relative prices is zero. This requirement can be incorporated into prices by employing the following two steps: First, multiply both sides of equation (4.1) by the budget share of good $i$ and sum over $\mathrm{i}=1, \ldots, \mathrm{n}$. As $\sum_{\mathrm{i}=1}^{\mathrm{n}} \mathrm{w}_{\mathrm{i}}\left(\log \mathrm{p}_{\mathrm{i}}-\log \mathrm{P}\right)=0$, we have $0=\mathrm{A}+\mathrm{B} \log \mathrm{Q}$, where $\mathrm{A}=\sum_{\mathrm{i}=1}^{\mathrm{n}} \mathrm{w}_{\mathrm{i}} \alpha_{\mathrm{i}}^{\prime}$ and $\mathrm{B}=\sum_{\mathrm{i}=1}^{\mathrm{n}} \mathrm{w}_{\mathrm{i}} \beta_{\mathrm{i}}^{\prime}$ are budget share weighted means. Second, subtract $0=\mathrm{A}+\mathrm{B} \log \mathrm{Q}$ from both sides of (4.1) and multiply both sides by $\mathrm{w}_{\mathrm{i}}$ to give

$$
\mathrm{w}_{\mathrm{i}}\left(\log \mathrm{p}_{\mathrm{i}}-\log \mathrm{P}\right)=\alpha_{\mathrm{i}}+\beta_{\mathrm{i}} \log \mathrm{Q},
$$

where $\alpha_{\mathrm{i}}=\mathrm{w}_{\mathrm{i}}\left(\alpha_{\mathrm{i}}^{\prime}-\mathrm{A}\right)$ and $\beta_{\mathrm{i}}=\mathrm{w}_{\mathrm{i}}\left(\beta_{\mathrm{i}}^{\prime}-\mathrm{B}\right)$ are weighted deviations from their weighted means.

According to model (4.2), growth in income increases the relative price of good $i$ if $\beta_{\mathrm{i}}>0$, which occurs when $\beta_{\mathrm{i}}^{\prime}=\left(\theta_{\mathrm{i}}^{\mathrm{d}}-\theta_{\mathrm{i}}^{\mathrm{s}}\right) /\left(\eta_{\mathrm{i}}^{\mathrm{s}}-\eta_{\mathrm{i}}^{\mathrm{d}}\right)$ is greater than the average, B. Accordingly, income growth increases the relative price of $i$ when the ratio of the difference in the income elasticities in demand and supply to the excess supply elasticity is greater than average, and vice versa. Model (4.2) holds for $i=1, \ldots, n$ goods and the coefficients satisfy $\sum_{i=1}^{n} \alpha_{i}=\sum_{i=1}^{n} \beta_{i}=0$. This model also implies that $\beta_{\mathrm{i}} / \mathrm{w}_{\mathrm{i}}$ is the income elasticity of the relative price of good $\mathrm{i}$ and that a budget-share-weighted average of these elasticities, $\sum_{\mathrm{i}=1}^{\mathrm{n}} \mathrm{w}_{\mathrm{i}}\left(\beta_{\mathrm{i}} / \mathrm{w}_{\mathrm{i}}\right)=\sum_{\mathrm{i}=1}^{\mathrm{n}} \beta_{\mathrm{i}}$, is zero.

Equation (4.2) is a reduced form and the coefficients are somewhat complex functions of their structural counterparts. Some further insight is available in the special case when (i) the excess supply elasticity is the same for each commodity: $\eta_{\mathrm{i}}^{\mathrm{s}}-\eta_{\mathrm{i}}^{\mathrm{d}}=\Delta_{\mathrm{i}}=\Delta>0$; and (ii) each income elasticity of supply is unity: $\theta_{\mathrm{i}}^{\mathrm{s}}=1$. In this situation, 


$$
\mathrm{B}=\sum_{\mathrm{i}=1}^{\mathrm{n}} \mathrm{w}_{\mathrm{i}}\left(\frac{\theta_{\mathrm{i}}^{\mathrm{d}}-\theta_{\mathrm{i}}^{\mathrm{s}}}{\Delta_{\mathrm{i}}}\right)=\frac{1}{\Delta} \sum_{\mathrm{i}=1}^{\mathrm{n}} \mathrm{w}_{\mathrm{i}}\left(\theta_{\mathrm{i}}^{\mathrm{d}}-1\right)=0,
$$

where the third step is based on the requirement that a budget-share-weighted average of the income elasticities of demand is unity. The income coefficient in (4.2) is then

$$
\beta_{\mathrm{i}}=\frac{1}{\Delta} \mathrm{w}_{\mathrm{i}}\left(\theta_{\mathrm{i}}^{\mathrm{d}}-1\right)
$$

As $1 / \Delta$ and $w_{i}$ are both positive, this shows that $\beta_{i}>0$ for goods that are luxuries $\left(\theta_{i}^{d}>1\right)$ and negative for necessities $\left(\theta_{i}^{\mathrm{d}}<1\right)$. Higher income increases the relative prices of luxuries and decreases those of necessities, which is an attractively simple result. Moreover, this agrees with the finding of Section 2 of the lower relative price of food (a necessity) in rich countries.

As $\sum_{\mathrm{i}=1}^{\mathrm{n}} \mathrm{w}_{\mathrm{i}}\left(\beta_{\mathrm{i}} / \mathrm{w}_{\mathrm{i}}\right)=\sum_{\mathrm{i}=1}^{\mathrm{n}} \beta_{\mathrm{i}}=0$, the weighted variance of the income elasticities of the relative prices is $\sum_{\mathrm{i}=1}^{\mathrm{n}} \mathrm{w}_{\mathrm{i}}\left(\beta_{\mathrm{i}} / \mathrm{w}_{\mathrm{i}}\right)^{2}=\sum_{\mathrm{i}=1}^{\mathrm{n}} \beta_{\mathrm{i}}^{2} / \mathrm{w}_{\mathrm{i}}$, which in the case of (4.3) becomes

$$
\sum_{\mathrm{i}=1}^{\mathrm{n}} \frac{\beta_{\mathrm{i}}^{2}}{\mathrm{w}_{\mathrm{i}}}=\frac{1}{\Delta^{2}} \sum_{\mathrm{i}=1}^{\mathrm{n}} \mathrm{w}_{\mathrm{i}}\left(\theta_{\mathrm{i}}^{\mathrm{d}}-1\right)^{2} .
$$

The right-hand side of the above is proportional to the (weighted) variance of the income elasticities $\sum_{\mathrm{i}=1}^{\mathrm{n}} \mathrm{W}_{\mathrm{i}}\left(\theta_{\mathrm{i}}^{\mathrm{d}}-1\right)^{2}$, where the proportionality factor is $1 / \Delta^{2}>0$. A greater diversity of the quality of goods, in the eyes of the consumer, implies greater dispersion of income elasticities of demand and, from (4.4), greater variability of the income elasticities of the prices. ${ }^{6}$ For example, when all goods are of the same quality, the income elasticities of demand are all unity and there is no dispersion among the elasticities of the price. In this case, each $\beta_{\mathrm{i}}=0$, so relative prices are independent of income. By contrast, the more different are goods, the greater the impact of income growth on relative prices. While based on the simplified case of identical excess demand elasticities and equiproportional responses on the supply side to growth, this is still an intuitively plausible prediction.

\section{Application}

\footnotetext{
${ }^{6}$ In the log-linear case, the weighted variance of the income elasticities is the income elasticity of the demand for quality, where quality is measured by the covariance between the change in consumption of each of the $n$ goods and the income elasticities. See Clements and Gao (2012).
} 
We now apply model (4.2) to the 31 basic headings for food in 154 of the 155 countries in Table 2.1 (the US is omitted as it is the base country). This application refers to prices within the food sector, so we consider the price of each food item relative to the price of all foods. As before, let $\mathrm{w}_{\mathrm{ic}}^{\prime}$ be the share of basic heading $\mathrm{i}$ (or "food" i) of total food expenditure in country c; $\mathrm{p}_{\mathrm{ic}}$ be the corresponding price; $\log \mathrm{P}_{\mathrm{Fc}}=\sum_{\mathrm{i}=1}^{31} \mathrm{~W}_{\mathrm{ic}}^{\prime} \log \mathrm{p}_{\mathrm{ic}}$ be the food price index; and $\mathrm{Y}_{\mathrm{c}}=\mathrm{M}_{\mathrm{c}} / \mathrm{P}_{\mathrm{c}}$ be real income per capita in c. It is now convenient to measure income relative to the crosscountry geometric mean, $\log \left(Y_{c} / \bar{Y}\right)=\log Y_{c}-1 / 154 \cdot \Sigma_{c=1}^{154} \log Y_{c}$. After some experimentation, it was found to be desirable to allow the slope coefficient in (4.2) to vary across countries by taking the value $\beta_{\mathrm{i}}$ for the first and second income quartiles (to be referred to as "the rich countries") and $\beta_{\mathrm{i}}+\lambda_{\mathrm{i}}$ for the others ("the poor"). Accordingly, equation (4.2) becomes

$$
\mathrm{W}_{\mathrm{ic}}^{\prime} \log \left(\mathrm{p}_{\mathrm{ic}} / \mathrm{P}_{\mathrm{Fc}}\right)=\alpha_{\mathrm{i}}+\left(\beta_{\mathrm{i}}+\lambda_{\mathrm{i}} \mathrm{D}_{\mathrm{c}}\right) \log \left(\mathrm{Y}_{\mathrm{c}} / \overline{\mathrm{Y}}\right)+\varepsilon_{\mathrm{ic}},
$$

where $D_{c}$ is dummy variable that takes the value of 1 if the country belongs to the "poor" group and is 0 otherwise; and $\varepsilon_{\text {ic }}$ is a disturbance term with $\mathrm{E}\left(\varepsilon_{\mathrm{ic}}\right)=0$ and $\mathrm{E}\left(\varepsilon_{\mathrm{ic}}^{2}\right)=\sigma_{\mathrm{i}}^{2}$. As $\log \left(Y_{c} / \bar{Y}\right)=0$ for the country with mean income, $\alpha_{i} / w_{i c}^{\prime}$ is interpreted as the expectation of that country's relative price of i. The coefficients satisfy the constraints $\sum_{i=1}^{31} \alpha_{i}=\sum_{i=1}^{31} \beta_{i}=\sum_{i=1}^{31} \lambda_{i}=0$.

The estimates of model (4.5) for $i=1, \ldots, 31$ are given in Table 4.1. As can be seen, most of the intercepts are significant, which is to be expected since these are related to the prices in the average country, as discussed above. The negative sign of the first coefficient of column 2, for example, indicates that rice is significantly cheaper than other products in this average country. Many of the income coefficients for the rich countries (in column 3) are also significant, and several marginal effects for the poor are also significant (column 4). Columns 6 and 7 reveal that the largest income elasticity is for the price of rice in both the rich and poor countries; the smallest is for other cereals, again for both groups of countries. Finally, note from the last row of the table that the variance of the income elasticities of the prices for the rich countries is about 60 percent more than that for the poor. Under the simplifying assumptions mentioned above, this 
implies considerably greater dispersion among the income elasticities of demand for the rich, or more diversity the quality of food consumption. ${ }^{7}$

\footnotetext{
${ }^{7}$ We also tried other versions of model (4.5) with different specifications for the dummy for poor countries. These included (i) no poor dummy; (ii) poor dummies for the intercepts only; (iii) both intercept and slope dummies; and (iv) four income groups (one for each income quartile) instead of two. In all instances, the poor dummies were not statistically significant at the 10 percent level.
} 


\section{Exchange Rates and Prices}

In the absence of trade barriers, prices of the same good in different countries are linked by the law of one price (LOP). In its simplest form, the LOP states that an identical good will sell for the same price, expressed in terms of a common currency, in different locations, so that prices will be equalised across countries. The mechanism that brings equalisation about is arbitrage -- buying where the price is low and selling where it is high -- eliminates price differences. It is difficult, however, to find many commodities that conform to LOP in this stark, unalloyed form, but gold, with its high value-to-weight ratio and lack of barriers to international trade, might come close. Below, we discuss the main impediments to the LOP holding -transport costs (interpreted broadly) and nontraded goods. ${ }^{8}$

\section{Transport Costs}

In the absence to barriers to trade, a good is exported if the world price $\left(\mathrm{p}^{*}\right)$ exceeds the domestic price (p), while the good is imported if the reverse is true. In the presence of transport costs, the gap has to be sufficiently wide to cover these costs. The good does not enter into international trade when this condition is not satisfied. Thus, if transport costs are a fraction $\alpha$ of the producer price and assuming transport is paid for by the seller, the good is

$$
\text { Exported if } \mathrm{p}<\frac{\mathrm{p}^{*}}{(1+\alpha)} \text {; imported if } \mathrm{p}>\mathrm{p}^{*}(1+\alpha) \text {; otherwise, nontraded. }
$$

Condition (5.1) gives a range of prices for which the good is not traded, as in Figure 5.1 (Dornbusch, 1980, pp. 94-95). Given transport costs and a world price of $\mathrm{p}_{0}^{*}$, when the domestic price is below $\underline{\mathrm{p}}$, and we are at a point such as $\mathrm{X}$, the good is imported; and when it is above $\overline{\mathrm{p}}$ (at $\mathrm{Z}$, for example), it is exported. For a price anywhere in the range $\overline{\mathrm{p}}-\underline{\mathrm{p}}$ (such as $\mathrm{Y}$ ), the good is nontraded. This shows that as transport costs fall, the area of the "nontraded cone" shrinks and more goods would enter into international trade, other things remaining unchanged. Perhaps this is consistent with the trade expansion effects of the introduction of refrigerated shipping in the 1870s and containerisation in the 1950s and beyond. The figure also demonstrates the impact of domestic costs on tradability: Suppose the commodity is initially exported (point Z). Then, if

\footnotetext{
${ }^{8}$ The macroeconomic counterpart to the LOP is the purchasing power parity (PPP) hypothesis whereby the value of the country's currency is equal to the ratio of prices at home to those abroad. On an even broader scale, PPP is one of the key building blocks of the monetary approach to exchange rates (Frenkel and Johnson, 1978).
} 
costs and the price at home rise sufficiently and the world price remains unchanged, the good could transition first to being nontraded, and then imported, as the economy moves from the point $\mathrm{Z}$ to $\mathrm{Y}$ and then $\mathrm{X}$.

\section{Nontraded Goods}

Traded goods - those that enter into international trade - have prices determined in world markets. In the absence of barriers to trade, they could be expected to tend to satisfy the LOP, once transport costs are allowed for. The prices of the nontraded goods are determined by local conditions, so there is no strong reason for these to comply with the LOP. Many goods are neither purely traded nor nontraded, but a mixture made up of some raw materials, such as minerals and agricultural products (traded goods) and nontraded goods, the costs of which include wages, local taxes and charges, property rents and so on. In terms of Figure 5.1, as the relative importance of the nontraded inputs increase, the price points move (from above and below) towards the nontraded cone.

To illustrate the role of nontraded goods further, let the price of a commodity be $\mathrm{p}$ and the unit costs of traded and nontraded inputs be $\mathrm{C}_{\mathrm{T}}$ and $\mathrm{C}_{\mathrm{N}}$. If the industry is competitive, prices are driven down to costs, so that $\mathrm{p}=\mathrm{C}_{\mathrm{T}}+\mathrm{C}_{\mathrm{N}}$, or $\mathrm{p}=\mathrm{C}_{\mathrm{T}}(1+\gamma)$, where $\gamma=\mathrm{C}_{\mathrm{N}} / \mathrm{C}_{\mathrm{T}}$ is the ratio of nontraded to traded costs. Equivalently, $\gamma /(1+\gamma)=\mathrm{C}_{\mathrm{N}} /\left(\mathrm{C}_{\mathrm{T}}+\mathrm{C}_{\mathrm{N}}\right)$ is the share of nontraded in total costs, so that if, for example, nontraded costs are one half those of traded, $\gamma=0.5$ and $\gamma /(1+\gamma)=0.33$. A logarithmic comparison of the price of the good at home with that abroad, both expressed in the same currency, is

$$
\log \frac{\mathrm{p}}{\mathrm{p}^{*}}=\log \frac{\mathrm{C}_{\mathrm{T}}}{\mathrm{C}_{\mathrm{T}}^{*}}+\log \frac{1+\gamma}{1+\gamma^{*}},
$$

where the asterisk denotes the foreign country. When the traded goods costs are equalised, the first term on the right of the above vanishes, so that

$$
\log \frac{\mathrm{p}}{\mathrm{p}^{*}}=\log \frac{1+\gamma}{1+\gamma^{*}} \approx \gamma-\gamma^{*} .
$$

This reveals that if the nontraded inputs account for the same fraction of total costs in the two countries, then prices are equalised. When $\gamma=\gamma^{*}$ the costs of traded goods are scaled up by the same amount in each country, so that equalisation of traded goods costs amounts to equalisation 
of the whole price of the commodity. This demonstrates that nontraded goods per se do not prevent the LOP from holding. Rather, when the fraction of the price attributable to nontraded goods differs, the two prices differ according to equation (5.2).

Examples

As a preface to the tests of the LOP in subsequent sections, we shall use a couple of simple examples that help fix ideas. The first is the price of Big Mac (BM) hamburgers in 2011 for 57 countries, converted to US dollars using market exchange rates. ${ }^{9}$ The second is GDP per capita in 2011 in 175 countries, converted to US dollars using (i) market exchange rates, and (ii) PPP rates from the International Comparisons Program (World Bank, unpublished). Taken literally, if these prices satisfied the LOP, there would be no dispersion across countries as the prices would be equalised. Clearly, this is not the case in Figures 5.2 and 5.3, where with the standard deviation of the BM prices at about 35 percent and those of the two versions of GDP much higher.

However, panel A of Figure 5.4 reveals a surprisingly close relation between BM prices in local currency units and exchange rates; the slope coefficient here is 0.95 , close to the LOP value of 1. But the relationship is weaker in panel B for GDP and PPP exchange rates and even weaker for GDP and market rates (panel C). As GDPs are even less tradable than BMs, we would not expect them to exhibit as close a relation to exchange rates. Moreover, as PPP exchange rates include the prices of both traded and nontraded goods, they better reflect the whole spectrum of prices underlying GDP, so it is understandable that they track GDP better than market rates.

\section{Prices of 198 Food Items in 175 Countries}

In this section, we move from indexes of the prices of groups of goods to something closer to the actual prices paid by consumers and use unpublished data from the 2011 round of the ICP on 198 items of food in 175 countries. $^{10}$

\footnotetext{
${ }^{9}$ The data are from The Economist (ongoing). The BM prices form the basis for The Economist's famous Big Mac Index and "burgernomics". The early burgernomics papers were by Click (1996), Cumby (1996) and Ong (1995, 1997); for a review, see Clements et al. (2012).

${ }^{10}$ These product level items disaggregate the "basic headings" used earlier in the paper. For more information, see the Appendix.
} 
Let $\mathrm{p}_{\mathrm{ic}}$ be the price of item $\mathrm{i}$ in country $\mathrm{c}$ in local currency units (LCUs) and $\mathrm{S}_{\mathrm{c}}$ be the exchange rate for the currency of c, defined as the cost in LCUs of \$US1. Thus, a depreciation of the local currency means $S_{c}$ rises. Define the world price of $i$, measured in $\$ U S$, as $p_{i}^{*}$, so that $\mathrm{p}_{\mathrm{i}}^{*} \times \mathrm{S}_{\mathrm{c}}$ is the world price in LCUs. Under the strong version of the LOP, the domestic price equals the world price; that is, using LCUs, $p_{i c}=p_{i}^{*} \cdot S_{c}$. An example of the use of the strong version is the absolute PPP calculations underlying the Big Mac index of The Economist magazine. According to the weak version of the law, domestic and world prices are proportional. Suppose now that $\mathrm{p}_{\mathrm{ic}}=\mathrm{e}^{\mathrm{k}_{\mathrm{ic}}} \cdot \mathrm{p}_{\mathrm{i}}^{*} \cdot \mathrm{S}_{\mathrm{c}}$, where $\mathrm{e}^{\mathrm{k}_{\mathrm{ic}}}$ a proportionality "wedge" factor, defined as the ratio of prices, $e^{k_{i c}}=p_{i c} /\left(p_{i}^{*} \cdot S_{c}\right) \approx 1+k_{i c}$. The strong version of the LOP corresponds to $k_{i c}=0$. In a conventional time-series context, the weak version of the law means that the wedge between prices is a constant over time. In a cross-country (or cross-commodity) setting, the wedge is constant over countries (or commodities). The implication of the weak version is that the domestic price is proportional to the exchange rate and/or the world price; that is, the elasticity is unity. In logs, $\mathrm{p}_{\mathrm{ic}}=\mathrm{e}^{\mathrm{k}_{\mathrm{ic}}} \cdot \mathrm{p}_{\mathrm{i}}^{*} \cdot \mathrm{S}_{\mathrm{c}}$ becomes

$$
\text { (6.1) } \log \mathrm{p}_{\mathrm{ic}}=\mathrm{k}_{\mathrm{ic}}+\log \mathrm{p}_{\mathrm{i}}^{*}+\log \mathrm{S}_{\mathrm{c}} \text {. }
$$

We proxy the world price as a weighted average of the prices of the item in each country, with weights reflecting relative importance. Ideally, information on the relative importance at the product level should be used, but this is not available. The next best alternative is to use information from one level higher, that is, information pertaining to the corresponding basic heading. Thus, for example, for a given country, Jasmine rice and Basmati rice, both members of the basic heading "rice", are accorded the same weight. To set out the weighting scheme, let $\mathbf{C}_{\mathbf{i}}$ denote the set of countries in which product $i(i=1, \ldots, n)$ is represented in the data and let real consumption of $\mathrm{i}$ in country $\mathrm{c} \in \mathbf{C}_{\mathrm{i}}$ be $\mathrm{q}_{\mathrm{ic}}$. Products are aggregated into $\mathrm{G}<\mathrm{n}$ basic headings, denoted by $\mathbf{X}_{\mathrm{g}}, \mathrm{g}=1, \ldots, \mathrm{G}$. Measuring in US dollars so units are comparable, $\mathrm{Q}_{\mathrm{gc}}=\Sigma_{\mathrm{i} \in \mathbf{X}_{\mathrm{g}}} \mathrm{q}_{\mathrm{ic}}$ is consumption of group g in $\mathrm{c} \in \mathbf{C}_{\mathrm{i}}, \mathrm{Q}_{\mathrm{g} .}=\Sigma_{\mathrm{c} \in \mathbf{C}_{\mathrm{i}}} \mathrm{Q}_{\mathrm{gc}}$ is world consumption of $\mathrm{i}$ and $\mathrm{w}_{\mathrm{gc}}=\mathrm{Q}_{\mathrm{gc}} / \mathrm{Q}_{\mathrm{g}}$. is country c's share, with $\Sigma_{\mathrm{c} \in \mathbf{C}_{\mathrm{i}}} \mathrm{W}_{\mathrm{gc}}=1$. The world price of $\mathrm{i}$ is defined as a weighted geometric mean of the country prices, the logarithm of which is 


$$
\log p_{i}^{*}=\sum_{c \in \mathbf{C}_{i}} w_{g c} \log \left(\frac{p_{i c}}{S_{c}}\right), \quad i \in \mathbf{X}_{g}, i=1, \ldots, 198 .
$$

While this approach is not perfect, in the absence of direct information on world prices, it seems a reasonable working approximation.

The departure from the LOP is, from (6.1),

$$
\mathrm{k}_{\mathrm{ic}}=\log \mathrm{p}_{\mathrm{ic}}-\log \mathrm{p}_{\mathrm{i}}^{*}-\log \mathrm{S}_{\mathrm{c}} \text {. }
$$

International competitiveness is sometimes measured by the price level at home $(\mathrm{P})$ relative to that abroad, adjusted for the exchange rate $\left(\mathrm{S} \cdot \mathrm{P}^{*}\right)$, in the form $\log \left(\mathrm{P} / \mathrm{S} \cdot \mathrm{P}^{*}\right)$, which is known as the real exchange rate. Accordingly, measure (6.2) can be termed the "real relative price of commodity i in country c". The measure is "real" as there are no currency units, and "relative" as it compares the domestic and world prices. As it is unit free, it is comparable across commodities and countries.

To apply the above to the ICP data, the countries in the set $\mathbf{C}_{\mathrm{i}}$ are those for which prices are available. The left part of panel A of Figure 6.1 is a frequency distribution of $\mathrm{k}_{\mathrm{ic}}$ for all commodities and countries. The mean is about 16 percent and the distribution seems to be reasonably symmetric. Importantly, there is substantial dispersion as the logarithmic standard deviation is 0.55 , or more than 50 percent; and from the cumulative distribution on the right of the panel, only 40 percent of observations lie in the range $[-0.3,+0.3]$. Panel $\mathrm{B}$ shows that if we average over commodities, there is some compression -- the dispersion of the country means is considerably lower at about 27 percent and 65 percent now lie in the range $[-0.3,+0.3]$. Somewhat more compression emerges with the commodity means in panel C. One might imagine that with price differences of this order of magnitude, there must be major barriers that prevent arbitrage. But it is worth repeating that these are consumer goods, many of which contain large nontraded components; and by their very nature, the "prices" of nontraded components are not (cannot) be equalised across countries. Add to that the additional barriers such as transport costs, costs implicit in complying with health and safety regulations and the usual explicit taxes and charges that many governments impose on imported goods, and it becomes easier to understand the price differentials.

Figure 6.2 gives some more detail of the distribution of prices. Box plots of the commodities with the smallest and largest price dispersion are given in panel A. Irish whiskey 
and cream liqueur have the lowest spread, perhaps reflecting these are fairly standardised products. Additionally, international travellers are known to actively arbitrage price differences for spirits. ${ }^{11}$ Then comes whole chicken and tomato paste. Interestingly, these low-spread commodities have standard deviations (SDs) of the same order of magnitude as that of Big Mac hamburgers, viz., 20-35 percent. The agreement between the minimum-dispersion ICP commodities and Big Macs would seem reassuring if only because The Economist magazine regards the Big Mac as an "idealised" homogeneous good, well suited to PPP calculations based on the LOP. Chilies, cassava and bean curd are at the other end of the distribution with the highest dispersion (again in panel A of Figure 6.2). The SDs of these fall in the range 75-100 percent, which is substantially less than that of the two measures of GDP discussed in Section 5 (120-160 percent). Evidently, even the high-dispersion commodities are more tradable than GDP, which is quite reasonable. Panel B of the figure contains the countries with the lowest and highest dispersion - the differences between the low- and high-dispersion countries are smaller than the low-high differences for the commodities discussed above.

What might be the role of country affluence on relative prices? Richer countries possibly have deeper, more sophisticated markets and more often than not, fewer distortions, so prices in richer countries could be closer to their world counterparts, at least on average. If this were the case, the dispersion of prices in rich countries would be lower than that in poor ones. Figure 6.3, a cross-country scatter of the standard deviation of prices against income per capita, seems to support this idea as there is a broad tendency for dispersion to fall as income increases.

\section{More on Exchange Rates and Prices}

In this section, we test the law of one price using the ICP data presented in the previous section. Most tests of the LOP involve time-series data; by contrast, the tests that follow are carried out across countries for each item, and across items for each country.

\section{Cross-Country Regressions}

In view of equation (6.1), consider a cross-country regression for item $\mathrm{i}$ :

(7.1) $\log \mathrm{p}_{\mathrm{ic}}=\tilde{\alpha}_{\mathrm{i}}+\beta_{\mathrm{i}} \log \mathrm{S}_{\mathrm{c}}+\phi_{\mathrm{i}} \mathrm{k}_{\mathrm{ic}}+\tilde{\varepsilon}_{\mathrm{ic}}$

${ }^{11}$ It should also be noted that these prices come mostly from richer countries. 
where the intercept $\tilde{\alpha}_{\mathrm{i}}=\log \mathrm{p}_{\mathrm{i}}^{*}$, a constant for all countries; $\beta_{\mathrm{i}}$ and $\phi_{\mathrm{i}}$ are coefficients; and $\tilde{\varepsilon}_{\mathrm{ic}}$ is a zero-mean disturbance term. Under the LOP, $\beta_{\mathrm{i}}=\phi_{\mathrm{i}}=1$. Suppose that for a given $\mathrm{i}$, the wedge has a constant component, $\alpha_{k_{i}}$, so that $k_{i c}=\alpha_{k_{i}}+\left(k_{i c}-\alpha_{k_{i}}\right)$. The problem is that we cannot observe $\mathrm{k}_{\mathrm{ic}}$ in equation (7.1), so it becomes an omitted variable in the implementable regression

$$
\log \mathrm{p}_{\mathrm{ic}}=\alpha_{\mathrm{i}}+\beta_{\mathrm{i}} \log \mathrm{S}_{\mathrm{c}}+\varepsilon_{\mathrm{ic}}
$$

where $\alpha_{i}=\tilde{\alpha}_{i}+\phi_{i} \alpha_{k_{i}}$ is the intercept and $\varepsilon_{i c}=\phi_{i}\left(k_{i c}-\alpha_{k_{i}}\right)+\tilde{\varepsilon}_{i c}$ is a new disturbance term. As long as $\mathrm{k}_{\mathrm{ic}}$ and $\log \mathrm{S}_{\mathrm{c}}$ are uncorrelated, the OLS estimator of $\beta_{\mathrm{i}}$ will be unbiased (but inefficient). Obviously, if for a given item $\mathrm{i}, \mathrm{k}_{\mathrm{ic}}$ is the same across countries and only the intercept is affected, but this would seem unlikely to occur in practice.

Equation (7.2) is estimated across countries for $c=1, \ldots, C_{i} \leq 175$ observations for item $i$; and this regression is repeated for each of the $i=1, \ldots, 198$ food items. The 198 estimates of the slope coefficient $\beta_{\mathrm{i}}$ are given in Table 7.1 and plotted in Figure 7.1. The mean and median of the estimates are 0.96 and 0.97 , respectively. The majority are not too far away from 1 , the value implied by the LOP; from the cumulative distribution on the left of panel $\mathrm{C}$ of Figure 7.1, about 58 percent of the estimates are within the range $1 \pm 0.05$. There is still considerable dispersion among the estimates, which range from 0.81 (for sweet potatoes) to 1.06 (lemonade) and their standard deviation is 0.05 . It must also be acknowledged that a number of coefficients are significantly different from unity (from the right side of panel $\mathrm{C}$ of the figure, 65 percent), contradicting the LOP. But there does not seem to be any particular pattern to the estimates, other than the important property that the slope coefficients are clearly centred on a value close to unity.

The above tests use consumer prices that typically contain substantial elements of packaging and retailing, components that are mostly non-traded goods/services. For this reason, it might be plausibly argued that the LOP rejections are surprisingly modest. This position cannot be stated too firmly, however, due to the omitted-variable problem and the substantial percentage of slope coefficients significantly different from unity.

\section{Cross-Commodity Regressions}


For a given country c the exchange rate $S_{c}$ is constant, so the cross-commodity version of equation (7.1) is $\log \mathrm{p}_{\mathrm{ic}}=\tilde{\alpha}_{\mathrm{c}}^{\prime}+\beta_{\mathrm{c}}^{\prime} \log \mathrm{p}_{\mathrm{i}}^{*}+\phi_{\mathrm{c}}^{\prime} \mathrm{k}_{\mathrm{ic}}+\tilde{\varepsilon}_{\mathrm{ic}}^{\prime}$, where the intercept $\tilde{\alpha}_{\mathrm{c}}^{\prime}=\log \mathrm{S}_{\mathrm{c}}$. Expressing the wedge as $\mathrm{k}_{\mathrm{ic}}=\alpha_{\mathrm{k}_{\mathrm{c}}}^{\prime}+\left(\mathrm{k}_{\mathrm{ic}}-\alpha_{\mathrm{k}_{\mathrm{c}}}^{\prime}\right)$, where $\alpha_{\mathrm{k}_{\mathrm{c}}}^{\prime}$ is the constant component for country $\mathrm{c}$, the cross-commodity implementable regression takes the form

$$
\log \mathrm{p}_{\mathrm{ic}}=\alpha_{\mathrm{c}}^{\prime}+\beta_{\mathrm{c}}^{\prime} \log \mathrm{p}_{\mathrm{i}}^{*}+\varepsilon_{\mathrm{ic}}^{\prime},
$$

where $\tilde{\alpha}_{\mathrm{c}}^{\prime}=\log \mathrm{S}_{\mathrm{c}}+\phi_{\mathrm{c}}^{\prime} \alpha_{\mathrm{k}_{\mathrm{c}}}^{\prime}$, a constant for all items; $\beta_{\mathrm{c}}^{\prime}$ is a coefficient; and $\varepsilon_{\mathrm{ic}}^{\prime}=\phi^{\prime}\left(\mathrm{k}_{\mathrm{ic}}-\alpha_{\mathrm{k}_{\mathrm{c}}}\right)+\tilde{\varepsilon}_{\mathrm{ic}}^{\prime}$ is a disturbance. The LOP for the country as a whole implies $\beta_{\mathrm{c}}^{\prime}=1$, or that the elasticity of domestic prices with respect to world prices is unity. As before, there is an omitted-variable issue due to the neglect of the wedge factor. ${ }^{12}$

For country c equation (7.3) is estimated with data on $n_{c} \leq 198$ items and the estimated slope coefficients are given in Table 7.2 and Figure 7.2. These estimates are somewhat lower than previously -- the mean and median are 0.92 and 0.93 . Their standard deviation is now about twice as large at 0.11 . The proportion of the slopes falling in the range $1 \pm 0.05$ is now smaller at 27 percent (previously 58 percent); 53 percent are significantly different from unity (less than before, when this percentage was 65). There is no clear pattern in the estimates across countries.

That the estimates are, on average, not so far from unity in this case is perhaps also surprising. In addition to the issue of using of consumer prices mentioned above, there are two more reasons for surprise for this result. First, the approach used to proxy world prices is only a first approximation and certainly imperfect. Any measurement error in the world price leads to a downward bias in the estimated slope coefficients. Second, the orthogonality condition for unbiasedness with the omitted variable would seem more problematic in this case. This condition requires that the price wedge be uncorrelated with world prices. This would appear to rule out the (probably not unusual) case when following a decline in world prices, a country imposes import tariffs and the like in order to stabilise prices and protect its import-competing producers.

\section{Producer Prices}

\footnotetext{
${ }^{12}$ It is to be noted that (7.3) does not involve a regression of prices on themselves. Rather, it is a regression of the prices of the commodities produced in country $\mathrm{c}$ on the corresponding world prices. The world prices are the crosscountry weighted means of the prices, converted from local currency units to \$US.
} 
The previous material analysed the law of one price with a cross section of countries for one year. We now augment this with tests with an added time dimension to consider the prices of a number of commodities across countries and time, so the data are in the form of a series of panels. Another difference is that previously prices paid by consumers were used, while in this section prices received by producers are employed. Producer prices possibly come closer to international trade transaction prices, so the arbitrage mechanism underlying the LOP might operate more effectively in this case.

For domestic prices, we use annual price data from the Food and Agriculture Organization (FAO) on 208 food and agricultural items in 162 countries over the 24-year period 1991 - 2014 (FAO, online). These are prices "received by farmers... as collected at the point of initial sale (prices paid at the farm-gate)" (FAO, online). For the world price, we adopt the approach of Mundlak and Larson (1992) and use a weighted average of export prices, with weights reflecting the relative importance of each country in international trade. Let $x_{\text {ict }}$ be the real value of exports of commodity $i(i=1, \ldots, n)$ from country $c(c=1, \ldots, C)$ in year $t$, measured in \$US, so that $\mathrm{X}_{\mathrm{ct}}=\sum_{\mathrm{c}=1}^{\mathrm{C}} \mathrm{X}_{\mathrm{ict}}$ is "world" trade in the commodity and $\mathrm{w}_{\mathrm{ict}}=\mathrm{X}_{\mathrm{ict}} / \mathrm{X}_{\mathrm{ct}}$ is country c's share. The world price, in logarithmic form, of $\mathrm{i}$ in $\mathrm{t}$ is defined as

$$
\log \mathrm{p}_{\mathrm{it}}^{*}=\sum_{\mathrm{c}=1}^{\mathrm{c}} \mathrm{w}_{\text {ict }} \log \left(\frac{\mathrm{p}_{\text {ict }}^{\mathrm{x}}}{\mathrm{S}_{\mathrm{ct}}}\right), \mathrm{i}=1, \ldots, \mathrm{n} \text { items, }
$$

where $\mathrm{p}_{\mathrm{ict}}^{\mathrm{x}}$ is the corresponding export price in c, in local currency units, and $\mathrm{S}_{\mathrm{c}}$ is country c's exchange rate against the \$US. This approach to measuring world prices is similar to that used in Section 6. The export data are also from FAO (online).

As before, the deviation from the LOP is $k_{\text {ict }}=\log p_{\text {ict }}-\log \mathrm{p}_{\mathrm{it}}^{*}-\log \mathrm{S}_{\mathrm{ct}}$, the difference between the domestic price and the world price, The term $\mathrm{k}_{\mathrm{ict}}$ is also called the real relative price of commodity $\mathrm{i}$ in country c. Panel A of Figure 8.1 presents distributions of the $\mathrm{k}_{\mathrm{ict}}$. The mean is -0.27 , which may not be considered to be too large in view of recent estimates of trade costs. ${ }^{13}$

\footnotetext{
13 Anderson and van Wincoop (2004) roughly estimate the total trade cost for a rich country to be equivalent to a 170-percent ad-valorem tax. This encompasses both domestic (retail and wholesale distribution) and international (transport and border-related trade barriers) costs of around 55 percent and 74 percent, respectively. The authors draw upon a mixture of literature that employ direct and indirect (inference from trade volumes and prices) measures to determine trade costs; however, they emphasise the incomplete and sparseness of data available across countries. According to Anderson and van Wincoop, policies that directly affect trade, such as tariffs and quotas, are less
} 
But the dispersion is high as the standard deviation is 0.86 and the tails of the distribution are long with only about 25 percent of the observations lying in the range [-0.3, 0.3]. Panels $\mathrm{B}$ and $\mathrm{C}$ of the figure plot, for all years, the distribution of the country means, $\overline{\mathrm{k}}_{\text {.ct }}=\frac{1}{\mathrm{n}} \sum_{\mathrm{i}=1}^{\mathrm{n}} \mathrm{k}_{\mathrm{ict}}$, and the commodity means, $\overline{\mathrm{k}}_{\mathrm{i} \cdot \mathrm{t}}=\frac{1}{\mathrm{C}} \sum_{\mathrm{c}=1}^{\mathrm{C}} \mathrm{k}_{\mathrm{ict}}$. The variance of the former (which measures the country effect) is $0.58^{2}=0.34$, while that of the latter (the commodity effect) is $0.53^{2}=0.28$, reconfirming the dominance of the country effect. The greater variance of the cross-country component is largely due to extreme values in both tails. ${ }^{14}$

\section{Variance Decompositions}

In this section, we use the FAO data to investigate the source of deviations from the LOP with descriptive decompositions of their variance. Assuming for simplicity a balanced structure for each panel, the mean and variance of the deviations, over all countries and commodities, at time $\mathrm{t}$ are:

$$
\overline{\mathrm{k}}_{. . \mathrm{t}}=\frac{1}{\mathrm{nC}} \sum_{\mathrm{i}=1}^{\mathrm{n}} \sum_{\mathrm{c}=1}^{\mathrm{C}} \mathrm{k}_{\mathrm{ict}}, \quad \sigma_{. . \mathrm{t}}^{2}=\frac{1}{\mathrm{nC}} \sum_{\mathrm{i}=1}^{\mathrm{n}} \sum_{\mathrm{c}=1}^{\mathrm{C}}\left(\mathrm{k}_{\mathrm{ict}}-\overline{\mathrm{k}}_{. . \mathrm{t}}\right)^{2} .
$$

These can be termed the grand mean and variance at time $t$. If there are $\mathrm{T}$ years, we have $\mathrm{T}$ grand variances, $\sigma_{. .1}^{2}, \ldots, \sigma_{. . \mathrm{T}}^{2}$. Define the overall grand variance as the mean

$$
\sigma_{. . .}^{2}=\frac{1}{\mathrm{~T}} \sum_{\mathrm{t}=1}^{\mathrm{T}} \sigma_{. . \mathrm{t}}^{2} .
$$

Is it the variability over commodities or countries that contribute most to the grand variance? We shall investigate this issue using two decompositions of $\sigma_{. .0}^{2}$.

\section{A Commodity Decomposition}

Consider the real price of commodity $\mathrm{i}$ in the $\mathrm{C}$ countries, $\mathrm{k}_{\mathrm{ilt}}, \ldots, \mathrm{k}_{\mathrm{iCt}}$. The mean and variance are

$$
\overline{\mathrm{k}}_{\mathrm{i} \bullet \mathrm{t}}=\frac{1}{\mathrm{C}} \sum_{\mathrm{c}=1}^{\mathrm{C}} \mathrm{k}_{\mathrm{ict}}, \quad \sigma_{\mathrm{i} \bullet \mathrm{t}}^{2}=\frac{1}{\mathrm{C}} \sum_{\mathrm{c}=1}^{\mathrm{C}}\left(\mathrm{k}_{\mathrm{ict}}-\overline{\mathrm{k}}_{\mathrm{i} \bullet \mathrm{t}}\right)^{2} .
$$

important for trade costs than other policies such as those pertaining to transport infrastructure, property rights, regulation and language. Thus, developing countries generally have much higher trade costs. Trade costs also vary substantially across products.

${ }^{14}$ Comparing Figures 6.1 and 8.1, it can be seen that the dispersion of the deviations of the producer prices exceeds that of the consumer prices. This might be accounted for by the additional time variation in the producer prices. 
A natural measure of the dispersion of prices of all $n$ commodities is the mean of $\sigma_{i \cdot t}^{2}, \ldots, \sigma_{n \bullet t}^{2}$, that is, $\frac{1}{n} \sum_{\mathrm{i}=1}^{\mathrm{n}} \sigma_{\mathrm{i} \cdot \mathrm{t}}^{2}$. The conventional label for this mean might be the "within-commodity variance". But $\sigma_{i \bullet t}^{2}$ refers to differences across countries of the prices of the same commodity; the more dispersion among the deviations across countries, the larger is $\frac{1}{n} \sum_{\mathrm{i}=1}^{\mathrm{n}} \sigma_{\mathrm{i} \cdot \mathrm{t}}^{2}$. Accordingly, it is more useful to refer to this mean as the cross-country component of the grand variance:

$$
\theta_{\text {country }, \mathrm{t}}^{2}=\frac{1}{\mathrm{n}} \sum_{\mathrm{i}=1}^{\mathrm{n}} \sigma_{\mathrm{i} \cdot \mathrm{t}}^{2} .
$$

The corresponding "between-commodity variance" is the dispersion of the commodity means around the grand mean, which shall be referred to as the cross-commodity variance:

$$
\theta_{\text {Comm }, \mathrm{t}}^{2}=\frac{1}{\mathrm{n}} \sum_{\mathrm{i}=1}^{\mathrm{n}}\left(\overline{\mathrm{k}}_{\mathrm{i} \cdot \mathrm{t}}-\overline{\mathrm{k}}_{. \cdot \mathrm{t}}\right)^{2}
$$

where $\overline{\mathrm{k}}_{\cdot \cdot \mathrm{t}}=\frac{1}{\mathrm{n}} \sum_{\mathrm{i}=1}^{\mathrm{n}} \overline{\mathrm{k}}_{\mathrm{i} \cdot \mathrm{t}}=\frac{1}{\mathrm{nC}} \sum_{\mathrm{i}=1}^{\mathrm{n}} \sum_{\mathrm{c}=1}^{\mathrm{C}} \mathrm{k}_{\mathrm{ict}}$ is the grand mean. Using the above concepts, it can be easily shown that the grand variance is made up of the country and commodity components:

$$
\sigma_{. . \mathrm{t}}^{2}=\theta_{\substack{\text { Cross- }- \\ \text { country }, \mathrm{t}}}^{2}+\theta_{\substack{\text { Cross- }-\mathrm{t} \\ \text { comm }}}^{2}
$$

\section{A Country Decomposition}

Next, consider the price of each of the $\mathrm{n}$ commodities in country $\mathrm{c}, \mathrm{k}_{\mathrm{lct}}, \ldots, \mathrm{k}_{\mathrm{nct}}$. The mean and variance are

$$
\overline{\mathrm{k}}_{\cdot \mathrm{ct}}=\frac{1}{\mathrm{n}} \sum_{\mathrm{i}=1}^{\mathrm{n}} \mathrm{k}_{\mathrm{ict}}, \quad \sigma_{\cdot \mathrm{ct}}^{2}=\frac{1}{\mathrm{n}} \sum_{\mathrm{i}=1}^{\mathrm{n}}\left(\mathrm{k}_{\mathrm{ict}}-\overline{\mathrm{k}}_{\cdot \mathrm{ct}}\right)^{2} .
$$

The mean of the $\mathrm{C}$ variances, $\sigma_{\cdot \mathrm{lt}}^{2}, \ldots, \sigma_{\cdot \mathrm{Ct}}^{2}$, is the within-country dispersion of prices. As this measures the variability of prices across commodities, we shall call this the cross-commodity variance,

$$
\phi_{\text {Comm }, \mathrm{t}}^{2}=\frac{1}{\mathrm{C}} \sum_{\mathrm{c}=1}^{\mathrm{C}} \sigma_{\text {.ct }}^{2} .
$$

The dispersion of the country means around the grand mean is

$$
\underset{\text { country }, \mathrm{t}}{\phi_{\text {Cross- }}^{2}}=\frac{1}{\mathrm{C}} \sum_{\mathrm{c}=1}^{\mathrm{C}}\left(\overline{\mathrm{k}}_{\cdot \mathrm{ct}}-\overline{\mathrm{k}}_{. \mathrm{t}}\right)^{2}
$$


where $\overline{\mathrm{k}}_{\cdot \cdot \mathrm{t}}=\frac{1}{\mathrm{C}} \sum_{\mathrm{c}=1}^{\mathrm{C}} \overline{\mathrm{k}}_{\cdot \mathrm{ct}}=\frac{1}{\mathrm{nC}} \sum_{\mathrm{i}=1}^{\mathrm{n}} \sum_{\mathrm{c}=1}^{\mathrm{C}} \mathrm{k}_{\mathrm{ict}}$. The grand variance can then be decomposed into new commodity and country effects:

$$
\sigma_{. . \mathrm{t}}^{2}=\phi_{\substack{\text { Cross- } \\ \text { comm }, \mathrm{t}}}^{2}+\phi_{\substack{\text { Counstry }, \mathrm{t} \\ \text { cous }}}^{2}
$$

Decompositions (9.1) and (9.2) both yield measures of the commodity and country variance. Due to the different basis underlying each decomposition, in general the effects are not the same, however. Something can be said about the discrepancy as equations (9.1) and (9.2) imply that the differences in the two types of variances coincide:

$$
\theta_{\text {Couss- }}^{2}-\underset{\text { country, }, \mathrm{t}}{2}-\underset{\substack{\text { Cross- } \\ \text { comm }, \mathrm{t}}}{2}-\theta_{\text {Cromm }, \mathrm{t}}^{2} \neq 0
$$

\section{Application}

Column 2 of Table 9.1 gives the grand standard deviation of the deviations from the LOP in each year for the FAO data. ${ }^{15}$ As can be seen, this starts off at about 1 in the early 1990s and then tends to decrease to end up at 0.80 in 2013. This 20-percent decrease in variability suggests markets are becoming more integrated over time, which is indirect evidence of reduced trade barriers of all kinds (trade policy, transport costs, information gaps, etc.).

The commodity-wise variance decomposition is given by equation (9.1). The values of the country and commodity components, expressed as percentages of the total, are contained in columns 3 and 4 of Table 9.1. The cross-country component clearly dominates as in most years it accounts for something like two-thirds or more of the grand variance. A different picture emerges for the country-wise decomposition [equation (9.2)]: From column 5, in the early years, the cross-country component is 50 percent or more; it then falls, before rising again to more than 50 percent in 2010-2012, and finally falls once more to end at 37 percent in 2013. Which measure should be relied upon? As the standard deviation of column 3 is less than one-fifth of that of column 5, it seems reasonable to use the former and conclude that the country effects dominate departures from the law of one price.

\footnotetext{
${ }^{15}$ As the panels are unbalanced, equations (9.1)-(9.3) now hold only approximately for two reasons. First, some of the panels yield a single observation for some countries and commodities. That is, some items are only produced by one country in a year and some countries only produce one item in a year. As their inclusion would distort our measures of dispersion, these panels are omitted. Since the number of omitted panels differs between the cross-country and cross-commodity measures for the same year, equation (9.3) no longer holds exactly. Second, of the items with more than one observation in the commodity decomposition, the number of missing countries varies from item to item, whereas the above definitions of $\theta_{\text {Cross-country,t }}^{2}$ and $\theta_{\text {Cross-comm,t }}^{2}$ do not allow for this. Therefore, the grand variance computed directly from the unbalanced data is different from the sum of these components. The same problem also applies to the country decomposition.
} 


\section{Are the Deviations Stationary?}

Suppose that in some year the domestic and world prices are not equalised. The law of one price would then mean that deviation would be eliminated in subsequent years, that is, the deviations are stationary. In this section, we use the FAO data to test for the stationarity of the mispricing terms $\mathrm{k}_{\mathrm{ict}}$ using the panel model:

$$
\Delta \mathrm{k}_{\mathrm{ict}}=\alpha_{\mathrm{c}}+\beta_{\mathrm{c}} \mathrm{k}_{\mathrm{ic}, \mathrm{t}-1}+\sum_{\mathrm{p}=1}^{\mathrm{m}_{\mathrm{c}}} \phi_{\mathrm{cp}} \Delta \mathrm{k}_{\mathrm{ic}, \mathrm{t}-\mathrm{p}}+\varepsilon_{\mathrm{ict}}, \quad \mathrm{c}=1, \ldots, \mathrm{C}_{\mathrm{i}} .
$$

The hypothesis is then $\mathrm{H}_{0}: \beta_{\mathrm{c}}=0$ for $\mathrm{c}=1, \ldots, \mathrm{C}_{\mathrm{i}}$. A popular approach was proposed by Choi (2001), whereby the alternative is $\mathrm{H}_{\mathrm{A}}: \beta_{\mathrm{c}}<0$ for at least one $\mathrm{c}$; that is, the deviation is meanreverting in at least one country. The lag order $\mathrm{m}_{\mathrm{c}}$ is determined by the Akaike Information Criterion, and varies across countries. Significant negative values of $\beta_{c}$ provide evidence against the null hypothesis, implying that the deviations mean revert.

This approach uses the combination of significance levels derived from individual unitroot test statistics as follows:

- Let $\mathrm{G}_{\mathrm{c}}$ be the one-sided unit-root test statistic for country $\mathrm{c}$ (this is an ADF test statistic in our case, but it could be any unit root test). The asymptotic p-value for $G_{c}$ is $\mathrm{p}_{\mathrm{c}}=\mathrm{F}\left(\mathrm{G}_{\mathrm{c}}\right)\left[1-\mathrm{F}\left(\mathrm{G}_{\mathrm{c}}\right)\right]$, where $\mathrm{F}(\cdot)$ denotes the continuous distribution function corresponding to the random variable $\mathrm{G}_{\mathrm{c}}$ under the null.

- The combined test statistic is $\mathrm{Z}=\frac{1}{\sqrt{\mathrm{C}_{\mathrm{i}}}} \sum_{\mathrm{c}=1}^{\mathrm{C}_{\mathrm{i}}} \Phi^{-1}\left(\mathrm{p}_{\mathrm{c}}\right)$, where $\Phi(\cdot)$ is the standard normal cumulative distribution function and $\mathrm{C}_{\mathrm{i}}$ is the number of countries producing item $\mathrm{i}$. Here the p-values are used to define the so-called "probits" $t_{c}=\Phi^{-1}\left(p_{c}\right)$. Because each probit has a standard normal distribution by construction, this procedure is commonly referred to as an "inverse-normal method". Under the assumption of independent disturbances, Choi (2001) shows that $\mathrm{Z}$ follows an asymptotic standard normal distribution under the null.

Among the major advantages of this approach are (i) the allowance for country-specific intercepts and slope coefficients; and (ii) the number of time periods can vary across countries, that is, the panel can be unbalanced. Additionally, the test is applicable when the number of 
countries is large relative to the number of time periods. However, the main problem is that the Choi test does not account for cross-sectional dependence among the disturbances. This would seem to be important in agricultural market where common shocks to prices (such as a surge in demand) frequently occur. The dominant role of the US dollar in world markets means that a shock to that currency would possibly be transmitted to prices across countries, giving rise to further cross-sectional dependence. Ignoring such dependence could lead to size distortion and reduce much of the gain in power associated with the panel approach (O'Connell, 1998).

Hartung (1999) pointed out that dependency in the original test statistics $G_{c}$ can be characterized by the correlation among the probits $t_{c}$. He assumes a constant correlation structure of the $t_{c}$ and derives a consistent estimator using the observed $t_{c}$ together with a weighted inverse-normal test statistic that shall be denoted $\mathrm{Z}^{*}$-stat. Demetrescu et al. (2006) show this test is robust to deviation from the constant correlation assumption when the original statistics $G_{c}$ are multivariate normal. Even when normality does not hold, $Z^{*}$-stat has a superior performance for medium and strong correlations relative to tests that ignore cross-sectional dependence.

For each commodity, we estimate system (10.1) and Table 10.1 and Figure 10.1 contain the results. The mean $\mathrm{Z}^{*}$-stat and p-value are -3.24 and 0.06. Panel B of Figure 10.1 shows that in more than 75 percent of cases (commodities), the $\mathrm{Z}^{*}$-stat is smaller than the 5-percent critical value of a standard normal distribution (which is about -1.64 , using a one-tail test). Thus, for about three-quarters of the commodities we reject the null of a unit root with a 95-percent confidence. It seems safe to conclude the deviations mean-revert, which is evidence favourable to the law of one price.

\section{Concluding Comments}

The law of one price (LOP) states that identical goods sell as the same price. From microeconomic fundamentals, when prices are not equalised welfare can be improved by reallocating the product from the cheap location to the expensive one. The LOP is also important as it is at the heart of the purchasing power parity (PPP) theory of exchange rates, according to which the international value of the currency is the ratio of prices at home to those abroad. In the strong form of the LOP, prices are equalised absolutely. An example of an application of the strong version of the LOP is the popular Big Mac Index (BMI) of The Economist magazine. The 
BMI declares the currency of a country vis-à-vis the US dollar is over-valued when its hamburger price exceeds that in the US (and vice versa for an undervalued currency). The weak version of the law says domestic prices are only proportional to their world counterparts, and are not necessarily equal. When the proportionality factor is constant over time, for example, the weak version implies that the elasticity of domestic prices with respect to world prices is unity. One objective of the paper was to instigate the workings of the LOP with food and agricultural products. Another objective was to examine key characteristics of food prices paid by consumers - how the relative price of food and the dispersion of the prices of food items vary with the country's per capita income.

There were two basic parts to the paper. In the first part, we used data from the International Comparisons Project of the World Bank on consumer prices of food in a large number of countries in 2011 to show that (i) prices decline substantially as countries become richer; (ii) the dispersion of prices also falls with increasing affluence of countries; (iii) the prices of (a) rice and (b) other cereals and flour are particularly sensitive to country income, but the effects differ depending on whether the country is in the "rich" or "poor" group; and (iv) the LOP is rejected more often than not.

The second part of the paper dealt with producer prices of 124 agricultural products over countries and time. Using a panel-unit-root procedure, we tested for the LOP and found that in about three-quarters of the cases, the deviations from the law are stationary. Thus, prices mean revert to satisfy the LOP in its weak form. That the LOP seems to hold for such a large proportion of products might come as a surprise, especially as there was no attempt to control for commodity-specific factors, such as transport costs, import tariffs and other impediments to the equalisation of prices.

\section{$\underline{\text { References }}$}

Anderson, J. E., and E. van Wincoop (2004). “Trade Costs.” Journal of Economic Literature 42: 691-751.

Balassa, B. (1964). "The Purchasing Power Parity Doctrine: A Reappraisal.” Journal of Political Economy 72: 584-96.

Choi, I. (2001). "Unit Root Tests for Panel Data." Journal of International Money and Finance 20: 249-72.

Clements, K. W. and G. Gao (2012). "Quality, Quantity, Spending and Prices.” European Economic Review 56: 1376-91. 
Clements, K. W., G. Gao and T. Simpson (2013). "Disparities in Incomes and Prices Internationally." In K. W. Clements Currencies, Commodities and Consumption. Cambridge, UK: Cambridge University Press. Pp. 257-319.

Clements, K. W., Y. Lan and S. P. Seah (2012). "The Big Mac Index Two Decades On: An Evaluation of Burgernomics.” International Journal of Finance and Economics 17: 31-60.

Click, R. W. (1996). "Contrarian MacParity.” Economics Letters 53: 209-12.

Cumby, R. E. (1996). "Forecasting Exchange Rates and Relative Prices with the Hamburger Standard: Is What You Want What You Get with McParity?" NBER Working Paper 5675.

Demetrescu, M., U. Hassler, and A.-I. Tarcolea (2006). "Combining Significance of Correlated Statistics with Application to Panel Data." Oxford Bulletin of Economics and Statistics 68: 647-62.

Dornbusch, R. (1980). Open Economy Macroeconomics. New York, NY: Basic Books.

Dornbusch, R. (1988). "Purchasing Power Parity." In The New Palgrave: A Dictionary of Economics. New York: Stockton Press.

Food and Agriculture Organization (FAO) (2016) "Food Outlook" Biannual Report on Global Food Markets, June 2016, FAO, Rome, Italy.

FAO (online). Food and Agriculture Organization of the United Nations. Available at: http://www.fao.org/faostat/en/\#data/ [Accessed 9 Mar 2017].

Frenkel, J. A. (1978). "Purchasing Power Parity: Doctrinal Perspective and Evidence from the 1920s." Journal of International Economics 8: 169-91.

Frenkel, J. A., and H. G. Johnson, eds, (1978). The Economics of Exchange Rates: Selected Studies. Reading, Mass: Addison-Wesley.

Froot, K. A., and K. Rogoff (1995). "Perspectives on PPP and Long-Run Real Exchange Rates." In G. Grossman and K. Rogoff (eds) Handbook of International Economics. Volume 3. Amsterdam: North-Holland. Pp. 1647-88.

Hartung, J. (1999). “A Note on Combining Dependent Tests of Significance." Biometrical Journal 41: 849-55.

Manzur, M., ed, (2008). Purchasing Power Parity. Cheltenham, UK: Edward Elgar.

Marsh I. W., E. Passari and L. Sarno (2012). "Purchasing Power Parity in Tradable Goods." In J. James, I. W. Marsh and L. Sarno (eds) Handbook of Exchange Rates. Wiley. Pp. pp.189220.

Mundlak, Y., and D. F. Larson (1992). "On the Transmission of World Agricultural Prices." World Bank Economic Review 6: 399-422.

O'Connell, P. G. (1998). "The Overvaluation of Purchasing Power Parity." Journal of International Economics 44: 1-19.

Officer, L. H. (1982). Purchasing Power Parity and Exchange Rates: Theory, Evidence and Relevance. Greenwich, CT: JAI Press.

Ong, L. L. (1995, 1997). "Burgernomics: The Economics of the Big Mac Standard." Presented at the ANU/UWA PhD Conference in Economics and Business, The University of Western Australia. Published in Journal of International Money and Finance 16: 865-78.

Organization for Economic Cooperation and Development (OECD)/Food and Agriculture Organization (FAO). (2016). “OECD-FAO Agricultural Outlook 2016-2025.” OECD Publishing, Paris. DOI: http://dx.doi.org/10.1787/agr_outlook-2016-en

Rogoff, K. (1996). “The Purchasing Power Parity Puzzle." Journal of Economic Literature 34: 647-68. 
Samuelson, P. A. (1964). "Theoretical Problems on Trade Problems." Review of Economics and Statistics, 46: 145-54.

Taylor, A. M., and M. P. Taylor (2004). "The Purchasing Power Parity Debate." Journal of Economic Perspectives 18:135-58.

The Economist (ongoing). "The Big Mac Index". Available at: http://www.economist.com/ content/big-mac-index

U.S. Department of Agriculture (USDA) (2016). "USDA Agricultural Projections to 2025." Office of the Chief Economist, World Agricultural Outlook Board, Prepared by the Interagency Agricultural Projections Committee. Long-term Projections Report OCE2016-1, 99 pp.

World Bank (unpublished). 2011 International Comparison Program Data for Researchers. Washington, DC: World Bank. 
Table 2.1 Income and Food in 155 countries in 2011

\begin{tabular}{|c|c|c|c|c|c|c|c|c|c|}
\hline \multirow[b]{2}{*}{ Country } & \multirow{2}{*}{$\begin{array}{c}\text { Income } \\
\text { US = } \\
100 \\
(2)\end{array}$} & \multicolumn{3}{|c|}{ Food $(\times 100)$} & \multirow[b]{2}{*}{$\begin{array}{c}\text { Country } \\
\text { (6) }\end{array}$} & \multirow{2}{*}{$\begin{array}{c}\text { Income } \\
\text { US = } \\
100 \\
(7)\end{array}$} & \multicolumn{3}{|c|}{ Food $(\times 100)$} \\
\hline & & $\begin{array}{c}\text { Budget } \\
\text { share } \\
(3)\end{array}$ & $\begin{array}{c}\text { Relative } \\
\text { price } \\
(4)\end{array}$ & $\begin{array}{c}\text { Price } \\
\text { SD } \\
(5)\end{array}$ & & & $\begin{array}{c}\text { Budget } \\
\text { share } \\
(8)\end{array}$ & $\begin{array}{c}\text { Relative } \\
\text { price } \\
(9)\end{array}$ & $\begin{array}{c}\text { Price } \\
\text { SD } \\
(10)\end{array}$ \\
\hline \multicolumn{5}{|c|}{ A. First quartile } & \multicolumn{5}{|c|}{ B. Second quartile } \\
\hline 1. Bermuda & $11 \overline{0.7}$ & 10.0 & 8.4 & 27.6 & 40. Anguilla & 47.3 & 14.6 & 30.0 & 29.9 \\
\hline 2. United States & 100.0 & 6.9 & 0.0 & 0.0 & 41. Bahrain & 47.2 & 13.5 & 20.2 & 43.9 \\
\hline 3. Cayman Islands & 95.3 & 7.0 & 35.0 & 28.6 & 42. Czech & 43.4 & 16.3 & 16.9 & 21.3 \\
\hline 4. Hong Kong & 88.1 & 11.4 & 24.1 & 30.2 & 43. Bahamas & 43.1 & 10.5 & 27.6 & 32.7 \\
\hline 5. Norway & 87.7 & 10.5 & 23.1 & 26.1 & 44. Trini. \& Tob. & 42.6 & 21.7 & 51.7 & 31.8 \\
\hline 6. Luxembourg & 85.2 & 9.4 & -20.9 & 30.6 & 45. Poland & 40.9 & 19.0 & 14.4 & 22.9 \\
\hline 7. Switzerland & 82.0 & 9.5 & -7.6 & 43.3 & 46. Slovakia & 40.3 & 17.4 & 20.6 & 21.8 \\
\hline 8. UAE & 77.2 & 11.8 & 10.1 & 32.7 & 47. Barbados & 39.0 & 15.0 & 35.5 & 39.4 \\
\hline 9. Sweden & 76.3 & 9.9 & 0.7 & 23.9 & 48. Lithuania & 38.6 & 25.5 & 19.7 & 24.3 \\
\hline 10. Germany & 75.1 & 10.2 & 1.1 & 31.2 & 49. Oman & 37.5 & 19.5 & 30.0 & 36.8 \\
\hline 11. Australia & 74.6 & 10.2 & 7.2 & 19.8 & 50. St. Kitts \& Nevis & 37.2 & 19.2 & 60.1 & 30.8 \\
\hline 12. Austria & 74.5 & 9.6 & 7.2 & 29.6 & 51. Croatia & 36.5 & 22.2 & 34.9 & 19.8 \\
\hline 13. Denmark & 73.6 & 9.0 & 1.6 & 26.8 & 52. Hungary & 36.4 & 17.2 & 30.3 & 26.5 \\
\hline 14. Canada & 73.5 & 9.0 & 18.5 & 15.1 & 53. Russia & 35.6 & 30.4 & 38.0 & 24.5 \\
\hline 15. Iceland & 72.9 & 12.6 & 15.6 & 29.2 & 54. Chile & 35.5 & 15.9 & 32.8 & 29.9 \\
\hline 16. Finland & 72.5 & 11.6 & 2.2 & 24.9 & 55. Estonia & 35.5 & 21.4 & 24.3 & 20.8 \\
\hline 17. France & 72.0 & 11.4 & 1.7 & 32.9 & 56. Turkey & 34.9 & 22.4 & 41.5 & 34.0 \\
\hline 18. Belgium & 71.2 & 11.2 & -1.2 & 28.6 & 57. Montserrat & 34.5 & 17.6 & 51.7 & 42.1 \\
\hline 19. United Kingdom & 70.3 & 8.5 & -7.1 & 19.4 & 58. Uruguay & 34.3 & 19.4 & 33.3 & 29.5 \\
\hline 20. Netherlands & 70.3 & 9.3 & -11.8 & 26.7 & 59. Seychelles & 33.7 & 41.3 & 39.6 & 52.7 \\
\hline 21. Singapore & 70.0 & 7.1 & 30.3 & 36.6 & 60. Latvia & 33.6 & 21.9 & 29.6 & 25.8 \\
\hline 22. Taiwan & 68.1 & 12.4 & 42.8 & 31.5 & 61. Antigua \& Barb. & 32.3 & 16.7 & 58.2 & 35.1 \\
\hline 23. Aruba & 66.9 & 7.9 & 41.2 & 26.5 & 62. Montenegro & 29.7 & 35.6 & 29.5 & 27.2 \\
\hline 24. Macao & 65.4 & 9.8 & 28.9 & 33.2 & 63. Kazakhstan & 29.7 & 22.0 & 36.6 & 28.1 \\
\hline 25. Japan & 65.4 & 12.4 & 29.4 & 34.2 & 64. Mexico & 29.4 & 23.1 & 12.9 & 20.6 \\
\hline 26. Ireland & 63.1 & 9.6 & 7.8 & 19.4 & 65. Mauritius & 28.2 & 32.6 & 31.6 & 39.1 \\
\hline 27. Italy & 62.0 & 12.7 & 7.9 & 25.5 & 66. Malaysia & 27.7 & 17.5 & 31.5 & 34.2 \\
\hline 28. Cyprus & 60.7 & 13.9 & 20.3 & 22.7 & 67. Virgin Islands & 27.5 & 18.7 & 17.2 & 31.6 \\
\hline 29. New Zealand & 60.5 & 14.6 & 18.3 & 20.0 & 68. Panama & 27.1 & 17.5 & 36.8 & 37.4 \\
\hline 30. Spain & 57.5 & 12.6 & -0.7 & 20.1 & 69. Belarus & 26.8 & 36.9 & 41.4 & 40.0 \\
\hline 31. Israel & 55.6 & 13.8 & 22.1 & 31.4 & 70. Romania & 26.5 & 24.8 & 25.6 & 28.1 \\
\hline 32. Sint Maarten & 55.4 & 8.7 & 35.7 & 26.1 & 71. Bulgaria & 25.9 & 21.6 & 33.3 & 30.1 \\
\hline 33. Greece & 55.1 & 16.0 & 13.3 & 29.7 & 72. Serbia & 25.6 & 25.8 & 35.6 & 32.1 \\
\hline 34. Curaçao & 53.9 & 11.4 & 28.2 & 23.1 & 73. Brazil & 24.9 & 15.2 & 4.7 & 30.3 \\
\hline 35. Malta & 51.4 & 16.0 & 26.6 & 17.3 & 74. Costa Rica & 24.4 & 20.6 & 35.6 & 34.5 \\
\hline 36. Portugal & 49.1 & 16.0 & 1.1 & 25.4 & 75. Grenada & 24.2 & 20.9 & 42.3 & 43.0 \\
\hline 37. Slovenia & 48.8 & 14.4 & 12.5 & 23.8 & 76. Jordan & 24.0 & 27.9 & 58.2 & 41.1 \\
\hline 38. South Korea & 48.8 & 11.9 & 57.6 & 33.0 & 77. Dominican Rep. & 22.9 & 29.3 & 29.3 & 30.9 \\
\hline 39. Qatar & 48.6 & 10.7 & -11.8 & 40.4 & 78. Dominica & 22.8 & 17.8 & 47.9 & 45.8 \\
\hline Mean & 62.8 & 11.0 & 13.7 & 27.5 & Mean & 29.8 & 21.7 & 33.1 & 32.1 \\
\hline Mean Income (\$ p.c.) & \multicolumn{4}{|c|}{25,974} & Mean Income (\$ p.c.) & \multicolumn{4}{|c|}{12,341} \\
\hline
\end{tabular}


Table 2.1 Income and Food in 155 countries in 2011 (continued)

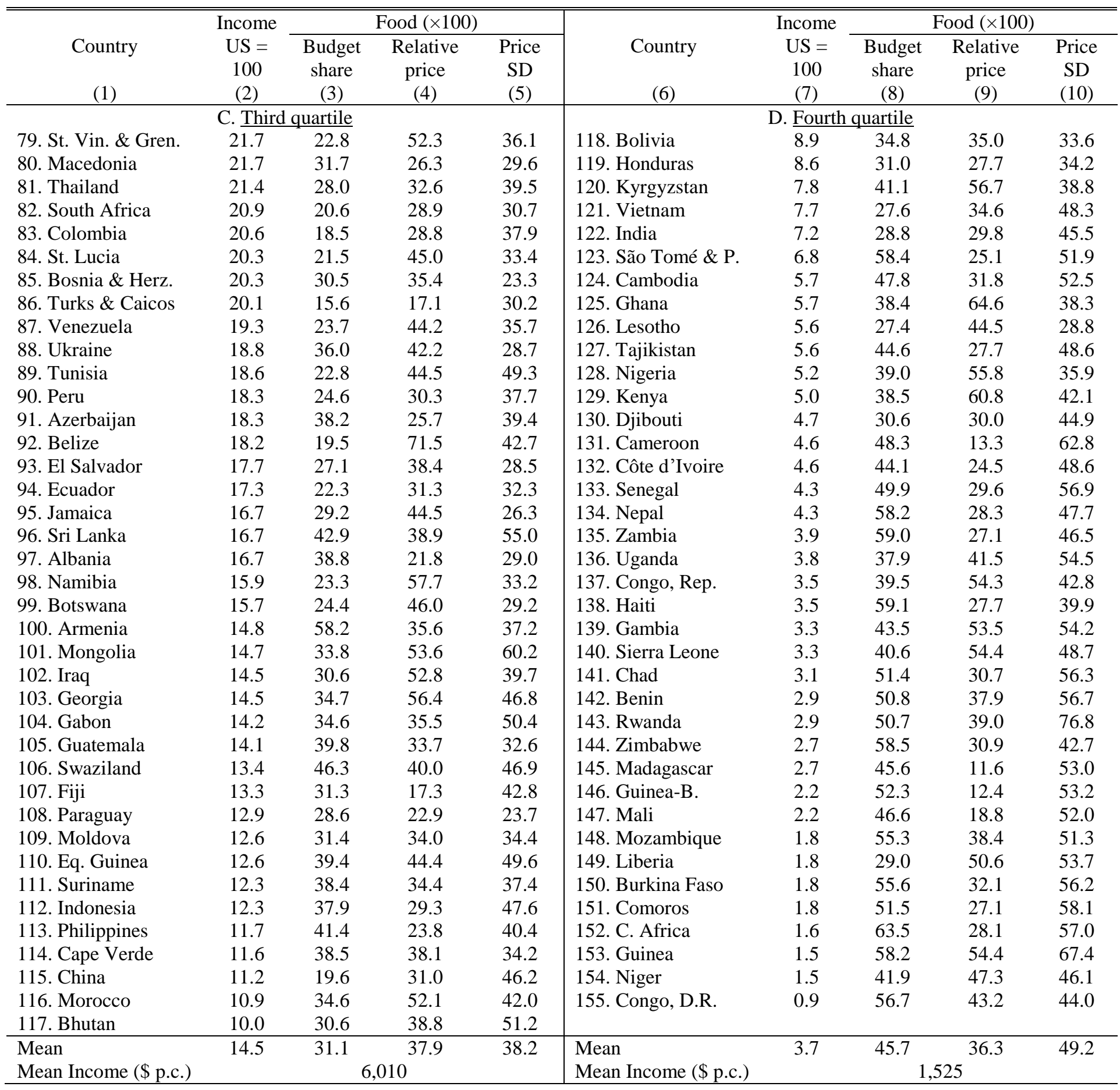

Notes: Countries are ranked in terms of per capita income and are divided into 4 quartiles. Income, contained in columns 2 and 7 , is defined as real total consumption per capita with US $=100$. More precisely, income is total consumption expenditure, defined as the sum of expenditure by households, non-profits serving households and individual government on 131 food and non-food items, deflated by the cost of living. That is, income is $\exp (\log \mathrm{M}-\log \mathrm{P})$, where $\mathrm{M}$ is total consumption expenditure, and $\log \mathrm{P}=\sum_{\mathrm{i}=1}^{131} \mathrm{w}_{\mathrm{i}} \log \mathrm{p}_{\mathrm{i}}$ is a cost-of-living index, with $\mathrm{w}_{\mathrm{i}}$ the budget share of good $\mathrm{i}$ (the proportion of total consumption expenditure devoted to i) and $\mathrm{p}_{\mathrm{i}}$ its PPP price. Food is defined as the sum of all 31 food items, including alcoholic beverages. These items are the first 31, so the total food budget share is $\mathrm{W}_{\mathrm{F}}=\sum_{\mathrm{i}=1}^{31} \mathrm{w}_{\mathrm{i}}$ and $\mathrm{w}_{\mathrm{i}}^{\prime}=\mathrm{w}_{\mathrm{i}} / \mathrm{W}_{\mathrm{F}}$ is the share of $\mathrm{i}$ within food (known as the "conditional budget-share"). The relative price of food is $\log \left(\mathrm{P}_{\mathrm{F}} / \mathrm{P}\right)=\log \mathrm{P}_{\mathrm{F}}-\log \mathrm{P}$, the difference between the conditional budget-share weighted $\operatorname{logarithmic}$ mean of the prices of the food items, $\log \mathrm{P}_{\mathrm{F}}=\Sigma_{\mathrm{i}=1}^{31} \mathrm{w}_{\mathrm{i}}^{\prime} \log \mathrm{p}_{\mathrm{i}}$, and the $\log$ of the cost-of-living index, $\log \mathrm{P}$. The food price standard deviation (SD) is $\sqrt{\sum_{\mathrm{i}=1}^{31} \mathrm{w}_{\mathrm{i}}^{\prime}\left(\log \mathrm{p}_{\mathrm{i}}-\log \mathrm{P}_{\mathrm{F}}\right)^{2}}$. The US is omitted from price means as it is the reference country. 
Table 3.1 Budget Shares and Prices of Food in 155 Countries

\begin{tabular}{|c|c|c|c|c|c|c|c|c|c|c|}
\hline \multirow{2}{*}{$\begin{array}{c}\text { Group/Item } \\
\text { (1) }\end{array}$} & \multicolumn{5}{|c|}{ Budget shares } & \multicolumn{5}{|c|}{ Relative prices } \\
\hline & $\begin{array}{l}\text { First } \\
(2)\end{array}$ & $\begin{array}{l}\text { Second } \\
\text { (3) }\end{array}$ & $\begin{array}{c}\text { Third } \\
\text { (4) }\end{array}$ & $\begin{array}{c}\text { Fourth } \\
\text { (5) }\end{array}$ & $\begin{array}{l}\text { All } \\
(6)\end{array}$ & $\begin{array}{l}\text { First } \\
(7)\end{array}$ & $\begin{array}{l}\text { Second } \\
\text { (8) }\end{array}$ & $\begin{array}{l}\text { Third } \\
(9)\end{array}$ & $\begin{array}{c}\text { Fourth } \\
(10)\end{array}$ & $\begin{array}{c}\text { All } \\
(11)\end{array}$ \\
\hline 1. BREAD AND CEREALS & 14.28 & 14.81 & 18.76 & 29.47 & 19.26 & -0.96 & -14.22 & -8.14 & -0.56 & -6.04 \\
\hline Rice & 9.87 & 15.86 & 25.05 & 38.24 & 22.15 & -21.65 & -12.44 & -28.55 & -42.16 & -26.12 \\
\hline Other cereals and flour & 13.57 & 17.04 & 26.93 & 38.84 & 24.00 & 13.89 & 50.34 & 63.10 & 66.24 & 48.50 \\
\hline Bread & 37.65 & 37.79 & 28.21 & 15.03 & 29.76 & -1.54 & -21.44 & -28.39 & -37.77 & -22.32 \\
\hline Other bakery products & 30.80 & 21.57 & 13.40 & 3.85 & 17.49 & -2.94 & 1.70 & -0.28 & 7.29 & 1.43 \\
\hline Pasta products & 8.11 & 7.75 & 6.40 & 4.04 & 6.59 & 11.04 & 39.15 & 44.21 & 47.73 & 35.61 \\
\hline 2. MEAT AND SEAFOOD & 24.36 & 24.53 & 22.41 & 21.10 & 23.11 & 9.06 & -3.60 & -10.70 & -20.67 & -6.49 \\
\hline Beef and veal & 15.18 & 13.98 & 21.16 & 25.08 & 18.81 & 24.16 & 4.50 & 2.15 & 4.34 & 8.72 \\
\hline Pork, lamb, mutton and goat & 15.67 & 16.63 & 15.14 & 17.44 & 16.21 & -3.94 & -12.61 & -6.86 & -23.15 & -11.61 \\
\hline Poultry & 15.66 & 24.21 & 24.56 & 13.77 & 19.59 & 23.98 & 22.57 & 36.71 & 71.37 & 38.54 \\
\hline Other meats and preparations & 28.62 & 24.09 & 13.74 & 7.93 & 18.66 & 11.62 & 14.80 & 30.29 & 61.29 & 29.41 \\
\hline Fresh or frozen fish and seafood & 15.40 & 14.59 & 19.83 & 20.39 & 17.53 & -39.75 & -36.31 & -33.81 & -46.90 & -39.14 \\
\hline Preserved fish and seafood & 9.48 & 6.51 & 5.57 & 15.41 & 9.20 & -20.33 & -8.09 & -3.91 & 13.24 & -4.79 \\
\hline 3. DAIRY & 13.16 & 15.89 & 15.76 & 11.64 & 14.13 & 7.05 & 20.79 & 30.07 & 49.16 & 26.75 \\
\hline Fresh milk & 19.94 & 15.53 & 16.71 & 18.67 & 17.71 & 1.69 & -4.91 & -4.58 & 11.76 & 0.92 \\
\hline Preserved milk and milk products & 28.16 & 30.82 & 27.70 & 17.59 & 26.12 & -2.52 & -5.11 & -3.27 & -6.06 & -4.24 \\
\hline Cheese & 25.75 & 18.46 & 13.24 & 4.12 & 15.47 & 0.23 & 0.45 & -1.05 & 10.26 & 2.43 \\
\hline Eggs and egg-based products & 8.28 & 10.97 & 13.57 & 10.24 & 10.77 & 28.29 & 14.81 & 12.38 & 6.05 & 15.36 \\
\hline Butter and margarine & 7.65 & 8.08 & 7.88 & 10.58 & 8.54 & -27.84 & -33.68 & -32.97 & -41.98 & -34.11 \\
\hline Other edible oils and fats & 10.22 & 16.14 & 20.89 & 38.80 & 21.40 & 16.85 & 23.27 & 19.35 & 11.94 & 17.90 \\
\hline 4. FRUIT AND VEGETABLES & 16.25 & $\mathbf{1 7 . 2 5}$ & 19.12 & 20.56 & 18.28 & -5.00 & -5.27 & -12.00 & -19.87 & -10.51 \\
\hline Fresh or chilled fruit & 35.71 & 30.98 & 27.42 & 18.50 & 28.22 & -0.13 & -5.60 & -6.09 & -12.23 & -6.01 \\
\hline Frozen, preserved or processed fruits & 7.64 & 5.43 & 3.78 & 4.85 & 5.43 & 23.42 & 52.29 & 69.19 & 77.18 & 55.59 \\
\hline Fresh or chilled vegetables & 33.43 & 39.30 & 44.52 & 38.58 & 38.96 & -6.34 & -10.36 & -11.32 & -19.83 & -11.95 \\
\hline Fresh or chilled potatoes & 8.11 & 11.74 & 14.00 & 26.61 & 15.04 & 9.59 & 13.78 & 12.56 & 4.68 & 10.19 \\
\hline Frozen or preserved vegetables & 15.11 & 12.54 & 10.28 & 11.46 & 12.35 & 0.97 & 20.58 & 28.65 & 57.82 & 26.97 \\
\hline 5. SWEET THINGS & 5.95 & 5.16 & 4.93 & 4.06 & 5.03 & -2.48 & 2.75 & 0.13 & 20.21 & 5.11 \\
\hline Sugar & 10.55 & 38.97 & 49.82 & 75.62 & 43.53 & -6.99 & -6.51 & -9.82 & -0.38 & -5.96 \\
\hline Jams, marmalades and honey & 10.29 & 12.33 & 12.30 & 6.01 & 10.26 & 23.77 & 38.21 & 40.51 & 24.02 & 31.73 \\
\hline Confectionery, chocolate and ice cream & 79.16 & 48.69 & 37.88 & 18.37 & 46.21 & -1.85 & 3.34 & 5.15 & -3.72 & 0.78 \\
\hline 6. OTHER FOOD & 15.51 & 12.78 & 12.06 & 8.83 & 12.32 & -2.32 & 8.54 & 13.11 & 34.48 & 13.42 \\
\hline Food products n.e.c. & 35.65 & 30.74 & 40.67 & 50.97 & 39.44 & 1.87 & -5.88 & -6.52 & 0.28 & -2.61 \\
\hline Coffee, tea and cocoa & 17.06 & 20.42 & 17.89 & 16.16 & 17.89 & 9.02 & 18.17 & 10.55 & -8.06 & 7.51 \\
\hline Min. waters, soft drinks, fruit and veg. juices & 47.29 & 48.83 & 41.44 & 32.87 & 42.67 & -2.23 & -1.45 & 0.35 & 2.59 & -0.19 \\
\hline 7. ALCOHOL & 10.48 & 9.59 & 6.96 & 4.34 & 7.87 & -5.10 & 9.56 & 16.37 & 25.80 & 11.67 \\
\hline Spirits & 25.02 & 35.62 & 28.31 & 23.66 & 28.18 & 21.69 & 9.50 & 10.06 & 4.47 & 11.41 \\
\hline Wine & 37.34 & 21.65 & 16.50 & 23.43 & 24.74 & -3.47 & 16.28 & 40.46 & 36.90 & 22.62 \\
\hline Beer & 37.64 & 42.73 & 55.19 & 52.91 & 47.08 & -4.25 & -13.26 & -16.57 & -15.93 & -12.54 \\
\hline
\end{tabular}

Notes:

1. Columns 2-6: These are budget shares of food. Emboldened figures are the proportions of food expenditure devoted to the food groups; for a given income category these shares have a unit sum. Non-emboldened figures are the proportions of group expenditure devoted to items within the group; these also have a unit sum for a given income category.

2. Columns 7-11: These are relative food prices. Emboldened figures are $\log \mathrm{P}_{\mathrm{F}}^{\mathrm{g}}-\log \mathrm{P}_{\mathrm{F}}$, the deviations of the price of food group $\mathrm{g}$ from the overall price of food, where $\log \mathrm{P}_{\mathrm{F}}^{\mathrm{g}}=\Sigma_{\mathrm{i} S_{\mathrm{F}}^{\mathrm{g}}} \overline{\mathrm{w}}_{\mathrm{i}} \log \mathrm{p}_{\mathrm{i}}$ is the price of group $\mathrm{g}$, with $\overline{\mathrm{W}}_{\mathrm{i}}$ the share of $\mathrm{i}$ in expenditure on $\mathrm{g}, \mathbf{S}_{\mathrm{F}}^{\mathrm{g}}$ the set of goods belonging to group $\mathrm{g}$ and $\log \mathrm{P}_{\mathrm{F}}=\Sigma_{\mathrm{i}=1}^{31} \mathrm{w}_{\mathrm{i}}^{\prime} \log \mathrm{p}_{\mathrm{i}}$ the price of all 31 food items, with $\mathrm{w}_{\mathrm{i}}^{\prime}$ the proportion of food expenditure devoted to i. Non-emboldened are $\log$ price deviations of food items from that of the group, $\log \mathrm{p}_{\mathrm{i}}-\log \mathrm{P}_{\mathrm{F}}^{\mathrm{g}}$.

3. The US is omitted from price calculations as it is the reference country. All values are averaged over countries and $\times 100$. 
Table 3.2 Dispersion of Food Prices

\begin{tabular}{|c|c|c|c|c|c|c|c|c|c|c|}
\hline \multirow[b]{2}{*}{$\begin{array}{l}\text { Income } \\
\text { quartile }\end{array}$} & \multirow[b]{2}{*}{$\begin{array}{c}\text { Total } \\
\text { variance }\end{array}$} & \multicolumn{2}{|c|}{ Components } & \multicolumn{7}{|c|}{ Group variances } \\
\hline & & $\begin{array}{l}\text { Between } \\
\text { group }\end{array}$ & $\begin{array}{l}\text { Within } \\
\text { group }\end{array}$ & $\begin{array}{l}\text { Bread } \\
\text { and } \\
\text { cereals }\end{array}$ & $\begin{array}{c}\text { Meat and } \\
\text { seafood }\end{array}$ & Dairy & $\begin{array}{l}\text { Fruits and } \\
\text { vegetables }\end{array}$ & $\begin{array}{l}\text { Sweet } \\
\text { things }\end{array}$ & $\begin{array}{l}\text { Other } \\
\text { food }\end{array}$ & Alcohol \\
\hline (1) & (2) & (3) & (4) & (5) & (6) & (7) & (8) & (9) & (10) & (11) \\
\hline 1 & 7.95 & 3.24 & 4.72 & 4.80 & 8.00 & 3.88 & 2.82 & 1.52 & 1.22 & 7.51 \\
\hline 2 & 10.86 & 4.05 & 6.81 & 12.31 & 7.62 & 4.51 & 5.29 & 4.84 & 2.28 & 6.71 \\
\hline 3 & 15.38 & 6.25 & 9.13 & 19.69 & 10.77 & 4.65 & 6.72 & 8.58 & 1.97 & 8.32 \\
\hline 4 & 25.12 & 10.98 & 14.14 & 21.41 & 18.76 & 5.49 & 10.24 & 2.69 & 1.47 & 6.43 \\
\hline All & 14.81 & 6.12 & 8.69 & 14.57 & 11.26 & 4.63 & 6.26 & 4.44 & 1.74 & 7.24 \\
\hline
\end{tabular}

Notes:

1. Column 2: This contains the weighted logarithmic variance of the 31 food prices, $\Pi_{\mathrm{F}}=\Sigma_{\mathrm{i}=1}^{31} \mathrm{w}_{\mathrm{i}}^{\prime}\left(\log \mathrm{p}_{\mathrm{i}}-\log \mathrm{P}_{\mathrm{F}}\right)^{2}$, where $\mathrm{w}_{\mathrm{i}}^{\prime}$ is the proportion of food expenditure devoted to item $\mathrm{i}$ and $\log \mathrm{P}_{\mathrm{F}}=\Sigma_{\mathrm{i}=1}^{31} \mathrm{w}_{\mathrm{i}}^{\prime} \log \mathrm{p}_{\mathrm{i}}$ is an index of the price of food.

2. Columns 3 and 4: Dividing the 31 food prices into seven groups, $\mathbf{S}_{g}, g=1, \ldots, 7$, the total price variance can be decomposed into between- and within-group components:

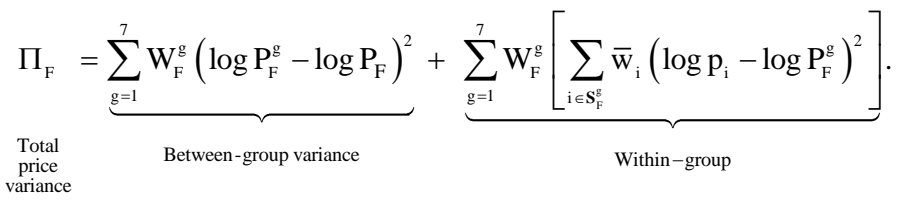

Here, $\mathrm{W}_{\mathrm{F}}^{\mathrm{g}}=\Sigma_{\mathrm{i} \in \mathrm{s}_{\mathrm{s}}} \mathrm{W}_{\mathrm{i}}^{\prime}$ is the budget share of group $\mathrm{g}$; $\log \mathrm{P}_{\mathrm{F}}^{\mathrm{g}}=\Sigma_{\mathrm{i} \in \mathrm{S}_{\mathrm{F}}^{\mathrm{g}}} \overline{\mathrm{W}}_{\mathrm{i}} \log \mathrm{p}_{\mathrm{i}}$ is the index of the price of $\mathrm{g}$, where $\overline{\mathrm{w}}_{\mathrm{i}}=\mathrm{w}_{\mathrm{i}}^{\prime} / \mathrm{W}_{\mathrm{F}}^{\mathrm{g}}$ is the share of group expenditure devoted to $\mathrm{i} \in \mathrm{S}_{\mathrm{F}}^{\mathrm{g}} ; \log \mathrm{P}_{\mathrm{F}}=\Sigma_{\mathrm{i}=1}^{31} \mathrm{w}_{\mathrm{i}}^{\prime} \log \mathrm{p}_{\mathrm{i}}=\Sigma_{\mathrm{g}=1}^{7} \mathrm{~W}_{\mathrm{F}}^{\mathrm{g}} \log \mathrm{P}_{\mathrm{F}}^{\mathrm{g}}$ is the price of all 31 food items. Columns 3 and 4, respectively, contain the above between- and within-group components.

3. Columns 5-11: These columns contain each of the seven within-group variances, $\Sigma_{\mathrm{i} \in S_{\mathrm{F}}^{\mathrm{g}}} \overline{\mathrm{w}}_{\mathrm{i}}\left(\log \mathrm{p}_{\mathrm{i}}-\log \mathrm{P}_{\mathrm{F}}^{\mathrm{g}}\right)^{2}$, $\mathrm{g}=1, \ldots, 7$.

4. All entries are averages over countries and $\times 100$. 
Table 4.1 Prices and Incomes, 31 Food Items in 154 countries in 2011

\begin{tabular}{|c|c|c|c|c|c|c|}
\hline \multirow{2}{*}{ Commodity } & \multirow{2}{*}{$\begin{array}{l}\text { Intercept } \\
\alpha_{i}(\times 100)\end{array}$} & \multicolumn{2}{|c|}{ Income coefficient $(\times 100)$} & \multirow{2}{*}{$\begin{array}{c}\text { SEE } \\
(\times 100)\end{array}$} & \multicolumn{2}{|c|}{$\begin{array}{c}\text { Income elasticity } \\
\text { of price }\end{array}$} \\
\hline & & $\begin{array}{c}\text { Rich } \beta_{i} \\
(3)\end{array}$ & $\begin{array}{l}\text { Marginal effect } \\
\text { for poor } \lambda_{i} \\
\text { (4) }\end{array}$ & & $\begin{array}{c}\text { Rich } \\
\beta_{\mathrm{i}} / \mathrm{w}_{\mathrm{i}}^{\prime} \\
(6)\end{array}$ & $\begin{array}{c}\text { Poor } \\
\left(\beta_{\mathrm{i}}+\lambda_{\mathrm{i}}\right) / \mathrm{w}_{\mathrm{i}}^{\prime} \\
(7)\end{array}$ \\
\hline 1. Rice & $-1.95(0.46)$ & $1.30(0.55)$ & $1.00(0.83)$ & 3.22 & 0.65 & 0.28 \\
\hline 2. Other cereals and flour & $1.89(0.37)$ & $-1.28(0.45)$ & $-1.40(0.67)$ & 2.60 & -0.58 & -0.31 \\
\hline 3. Bread & $-2.16(0.22)$ & $1.43(0.27)$ & $-1.82(0.40)$ & 1.55 & 0.26 & -0.09 \\
\hline 4. Other bakery products & $-0.29(0.06)$ & $0.09(0.08)$ & $-0.29(0.11)$ & 0.45 & 0.02 & -0.12 \\
\hline 5. Pasta products & $0.34(0.07)$ & $-0.17(0.08)$ & $0.12(0.12)$ & 0.46 & -0.15 & -0.05 \\
\hline 6. Beef and veal & $-0.40(0.21)$ & $1.13(0.25)$ & $-0.82(0.38)$ & 1.47 & 0.32 & 0.06 \\
\hline 7. Pork, Lamb, mutton and goat & $-0.74(0.29)$ & $0.48(0.35)$ & $0.07(0.52)$ & 2.03 & 0.12 & 0.15 \\
\hline 8. Poultry & $1.06(0.16)$ & $0.03(0.20)$ & $-0.16(0.30)$ & 1.16 & 0.01 & -0.03 \\
\hline 9. Other meats and preparations & $0.45(0.19)$ & $0.75(0.23)$ & $-0.95(0.34)$ & 1.34 & 0.12 & -0.08 \\
\hline 10. Fresh or frozen fish and seafood & $-2.02(0.37)$ & $0.26(0.44)$ & $0.64(0.66)$ & 2.57 & 0.07 & 0.20 \\
\hline 11. Preserved fish and seafood & $-0.25(0.11)$ & $-0.01(0.14)$ & $0.18(0.21)$ & 0.81 & 0.00 & 0.08 \\
\hline 12. Fresh milk & $0.52(0.13)$ & $-0.36(0.16)$ & $-0.04(0.24)$ & 0.95 & -0.14 & -0.15 \\
\hline 13. Preserved milk and milk products & $1.20(0.12)$ & $-0.80(0.15)$ & $1.03(0.22)$ & 0.87 & -0.19 & 0.08 \\
\hline 14. Cheese & $0.67(0.08)$ & $-0.44(0.09)$ & $0.67(0.14)$ & 0.53 & -0.13 & 0.16 \\
\hline 15. Eggs and egg-based products & $0.89(0.08)$ & $-0.41(0.10)$ & $0.59(0.14)$ & 0.56 & -0.30 & 0.11 \\
\hline 16. Butter and margarine & $-0.03(0.06)$ & $-0.21(0.07)$ & $0.15(0.10)$ & 0.39 & -0.18 & -0.05 \\
\hline 17. Other edible oils and fats & $1.57(0.15)$ & $-0.95(0.19)$ & $0.44(0.28)$ & 1.08 & -0.49 & -0.14 \\
\hline 18. Fresh or chilled fruit & $-1.18(0.20)$ & $0.77(0.24)$ & $-0.86(0.36)$ & 1.38 & 0.14 & -0.02 \\
\hline 19. Frozen, preserved or processed fruits & $0.37(0.07)$ & $-0.06(0.08)$ & $-0.05(0.12)$ & 0.48 & -0.06 & -0.13 \\
\hline 20. Fresh or chilled vegetables & $-2.17(0.35)$ & $1.34(0.42)$ & $-0.89(0.63)$ & 2.45 & 0.22 & 0.06 \\
\hline 21. Fresh or chilled potatoes & $0.04(0.38)$ & $-0.01(0.46)$ & $1.25(0.69)$ & 2.69 & -0.01 & 0.28 \\
\hline 22. Frozen or preserved vegetables & $0.37(0.13)$ & $-0.35(0.15)$ & $0.03(0.23)$ & 0.89 & -0.15 & -0.15 \\
\hline 23. Sugar & $-0.27(0.12)$ & $0.21(0.15)$ & $-0.64(0.23)$ & 0.88 & 0.17 & -0.16 \\
\hline 24. Jams, marmalades and honey & $0.25(0.03)$ & $-0.09(0.03)$ & $0.18(0.05)$ & 0.19 & -0.16 & 0.20 \\
\hline 25. Confectionery, chocolate and ice cream & $0.17(0.07)$ & $-0.37(0.08)$ & $0.41(0.12)$ & 0.48 & -0.10 & 0.03 \\
\hline 26. Food products n.e.c. & $0.15(0.19)$ & $-0.36(0.23)$ & $-0.59(0.34)$ & 1.31 & -0.07 & -0.18 \\
\hline 27. Coffee, tea and cocoa & $0.48(0.06)$ & $-0.21(0.08)$ & $0.30(0.11)$ & 0.45 & -0.09 & 0.06 \\
\hline 28. Min. water, soft drink, fruit \& veg juice & $0.66(0.14)$ & $-0.68(0.17)$ & $0.55(0.26)$ & 1.01 & -0.10 & -0.03 \\
\hline 29. Spirits & $0.36(0.17)$ & $0.10(0.21)$ & $0.01(0.31)$ & 1.21 & 0.03 & 0.07 \\
\hline 30. Wine & $0.31(0.17)$ & $-1.10(0.21)$ & $1.06(0.31)$ & 1.19 & -0.36 & -0.05 \\
\hline 31. Beer & $-0.29(0.16)$ & $-0.02(0.19)$ & $-0.18(0.29)$ & 1.11 & -0.01 & -0.06 \\
\hline Sum & 0 & 0 & 0 & - & - & - \\
\hline Weighted variance $100 \times \sum_{\mathrm{i}=1}^{31}\left(\beta_{\mathrm{i}}+\lambda \mathrm{D}\right)^{2} / \mathrm{w}_{\mathrm{i}}^{\prime}$ & - & - & - & - & 4.45 & 2.78 \\
\hline
\end{tabular}

Notes: For food item $\mathrm{i}$ in country $\mathrm{c}, \mathrm{w}_{\mathrm{ic}}^{\prime}$ is its expenditure share of food, $\mathrm{w}_{\mathrm{i}}^{\prime}$ its cross-country mean, $\log \mathrm{p}_{\mathrm{ic}}$ its $\log$ price and $\log \mathrm{P}_{\mathrm{Fc}}=\sum_{\mathrm{i}=1}^{31} \mathrm{w}_{\mathrm{ic}}^{\prime} \log \mathrm{p}_{\mathrm{ic}}$ is an index of food prices. Per capita income of c relative to the cross-country geometric mean is $\log \left(\mathrm{Y}_{\mathrm{c}} / \overline{\mathrm{Y}}\right) . \quad \mathrm{D}_{\mathrm{c}}$ is a dummy variable that takes the value of 1 if $\mathrm{c}$ belongs to the "poor" group (the third and fourth income quartiles) and is 0 otherwise; and $\varepsilon_{\text {ic }}$ is a disturbance term. Results exclude the USA, the base country. The income elasticities of price in columns 6 and 7 are evaluated at mean expenditure shares for the rich and poor countries. Standard errors in parentheses. 
Table 7.1 Slope Coefficients, Cross-Country Regressions, 198 Food Items

\begin{tabular}{|c|c|c|c|c|c|c|c|}
\hline $\begin{array}{c}\text { Item } \\
(1) \\
\end{array}$ & $\begin{array}{c}\text { Slope } \\
(2)\end{array}$ & $\begin{array}{c}\text { t-stat } \\
\text { (3) }\end{array}$ & $\begin{array}{c}\text { Obs } \\
(4) \\
\end{array}$ & $\begin{array}{c}\text { Item } \\
(5)\end{array}$ & $\begin{array}{c}\text { Slope } \\
(6)\end{array}$ & $\begin{array}{c}\text { t-stat } \\
(7)\end{array}$ & $\begin{array}{c}\text { Obs } \\
(8) \\
\end{array}$ \\
\hline 2. Long grain rice - Non-Parboiled & 0.93 & 5.65 & 95 & 64. Sea Bass & 0.83 & 6.67 & 64 \\
\hline 3. Long grain rice - Family Pack & 1.01 & 0.37 & 59 & 65. Whole Shrimps & 0.92 & 3.88 & 69 \\
\hline 4. Jasmine Rice & 1.02 & 1.24 & 60 & 66. Shrimps & 0.94 & 4.82 & 131 \\
\hline 5. Basmati Rice & 0.96 & 2.40 & 119 & 67. Squid & 0.90 & 5.22 & 84 \\
\hline 6. White rice, $25 \%$ broken & 0.94 & 3.12 & 59 & 68. Red snapper & 0.91 & 3.62 & 39 \\
\hline 7. White rice, Medium Grain & 0.93 & 4.22 & 66 & 69. Sea Crab & 0.96 & 1.73 & 46 \\
\hline 8. Brown rice - Family Pack & 0.97 & 1.44 & 48 & 70. Tilapia & 0.93 & 3.90 & 73 \\
\hline 9. Short-grained rice & 0.92 & 5.15 & 66 & 71. Black Pomfret & 0.90 & 4.32 & 30 \\
\hline 10. Cornflakes [Specified brand] & 1.02 & 2.49 & 161 & 72. Mullet & 0.88 & 4.78 & 33 \\
\hline 11. Wheat flour, not self-rising & 1.00 & 0.02 & 166 & 73. Canned sardine with skin & 0.94 & 4.90 & 161 \\
\hline 12. Wheat Semolina (Suji) & 1.05 & 1.66 & 60 & 74. Canned tuna without skin & 0.99 & 1.23 & 161 \\
\hline 13. Oats, rolled & 1.00 & 0.31 & 141 & 75. Canned mackerel fillet in vegetable oil & 0.99 & 0.61 & 111 \\
\hline 15. Couscous & 1.00 & 0.07 & 46 & 77. Dried Shrimp & 0.95 & 1.15 & 51 \\
\hline 16. Baguette & 0.90 & 5.82 & 124 & 78. Milk, un-skimmed Pasteurized & 1.01 & 0.66 & 151 \\
\hline 17. White bread & 0.94 & 3.13 & 118 & 79. Milk, un-skimmed UHT & 1.02 & 2.44 & 158 \\
\hline 18. Whole wheat bread & 0.95 & 3.05 & 138 & 80. Milk, low-fat, Pasteurized & 1.01 & 0.60 & 147 \\
\hline 19. Roll & 0.91 & 3.67 & 88 & 81. Milk, condensed & 0.95 & 3.28 & 75 \\
\hline 20. Sliced White bread & 0.95 & 3.67 & 158 & 82. Milk, powdered & 1.00 & 0.41 & 114 \\
\hline 21. Pita bread & 0.95 & 1.53 & 52 & 83. Yoghurt, plain & 0.98 & 1.59 & 157 \\
\hline 22. Sandwich biscuits/cookies & 0.98 & 1.45 & 155 & 84. Sour cream & 1.04 & 1.33 & 108 \\
\hline 23. Chocolate cake (Individual serving) & 0.96 & 2.15 & 68 & 85. Cheese, Cheddar & 1.01 & 0.97 & 110 \\
\hline 24. Chocolate cake (Whole) & 0.93 & 4.22 & 96 & 86. Cream cheese & 1.02 & 1.44 & 149 \\
\hline 25. All-butter croissant & 0.96 & 2.88 & 141 & 87. Cheese, processed & 1.00 & 0.04 & 161 \\
\hline 26. Butter biscuits & 0.96 & 2.85 & 150 & 88. Cheese, Camembert Type & 1.02 & 1.28 & 96 \\
\hline 27. Flavored biscuits/cookies sweet & 0.98 & 1.34 & 160 & 89. Cheese, Gouda Type & 1.01 & 0.84 & 124 \\
\hline 28. Salted crackers & 0.96 & 2.57 & 140 & 90. Bean Curd - Tofu & 0.95 & 0.72 & 32 \\
\hline 29. Short pasta & 1.02 & 1.54 & 138 & 91. Large size chicken eggs & 0.98 & 1.88 & 153 \\
\hline 30. Spaghetti & 0.97 & 3.07 & 171 & 92. Medium size chicken eggs & 0.97 & 2.33 & 108 \\
\hline 33. Vermicelli (Angel Hair) & 1.03 & 1.70 & 128 & 95. Margarine, regular fat & 0.99 & 0.88 & 168 \\
\hline 34. Macaroni & 0.97 & 2.22 & 118 & 96. Sunflower oil & 1.01 & 1.20 & 151 \\
\hline 35. Beef, Fillet & 0.87 & 6.70 & 155 & 97. Olive oil & 1.00 & 0.27 & 167 \\
\hline 36. Beef, Rump steak & 0.94 & 3.73 & 156 & 98. Palm oil & 0.99 & 0.33 & 58 \\
\hline 37. Beef, Center brisket & 0.92 & 6.72 & 134 & 99. Soybean oil & 1.00 & 0.24 & 94 \\
\hline 38. Beef, for stew or curry & 0.95 & 3.70 & 73 & 100. Peanut oil & 0.99 & 0.38 & 45 \\
\hline 39. Beef with bones & 0.93 & 5.02 & 116 & 101. Vegetable oil & 0.95 & 4.31 & 148 \\
\hline 40. $100 \%$ Beef, minced & 0.96 & 4.24 & 161 & 102. Apple, Red Delicious & 0.96 & 2.84 & 112 \\
\hline 41. Veal chops & 0.97 & 1.36 & 61 & 103. Banana, Standard & 0.90 & 7.38 & 173 \\
\hline 42. Veal breast (non-refrig.), w/ bones & 0.91 & 5.28 & 74 & 104. Grapes, green & 1.03 & 1.77 & 126 \\
\hline 43. Pork, loin chop & 0.94 & 5.26 & 138 & 105. Grapefruit & 0.92 & 4.64 & 100 \\
\hline 44. Pork, fillet & 0.95 & 3.56 & 134 & 106. Orange & 0.93 & 4.65 & 169 \\
\hline 45. Pork, shoulder & 0.96 & 2.21 & 60 & 107. Papaya & 0.85 & 8.44 & 96 \\
\hline 46. Pork, ribs & 0.96 & 3.17 & 150 & 108. Pineapple & 0.89 & 6.53 & 159 \\
\hline 47. Lamb whole leg & 0.90 & 6.35 & 132 & 109. Lemon & 0.91 & 5.77 & 160 \\
\hline 48. Lamb chops & 0.91 & 5.44 & 129 & 110. Mango & 0.85 & 6.39 & 93 \\
\hline 49. Mutton mixed cut & 0.95 & 2.86 & 64 & 111. Watermelon & 0.91 & 4.99 & 162 \\
\hline 50. Goat mixed cut non-refri. w/ bones & 0.92 & 4.27 & 59 & 112. Apple, Typical Local Variety & 1.01 & 0.32 & 108 \\
\hline 51. Whole chicken - Broiler & 1.00 & 0.47 & 144 & 113. Peach & 0.99 & 0.60 & 104 \\
\hline 52. Whole chicken & 1.00 & 0.43 & 149 & 114. Melon & 0.91 & 3.90 & 99 \\
\hline 53. Chicken breast without skin & 0.96 & 2.87 & 150 & 115. Tinned pineapple & 1.05 & 3.82 & 120 \\
\hline 54. Chicken legs & 0.98 & 2.11 & 159 & 116. Dried almonds & 1.01 & 0.57 & 58 \\
\hline 55. Live chicken & 1.00 & 0.28 & 65 & 117. Roasted groundnuts/peanuts & 0.92 & 4.74 & 118 \\
\hline 56. Chicken breast with skin and bones & 1.00 & 0.04 & 96 & 118. Mixed Fruits in Syrup & 0.99 & 0.51 & 106 \\
\hline 57. Pork ham, pressed & 0.95 & 3.09 & 109 & 119. Dried dates & 0.98 & 1.43 & 98 \\
\hline 58. Bacon, smoked & 0.98 & 1.73 & 115 & 120. Cucumber & 0.90 & 6.35 & 172 \\
\hline 59. Beef liver & 0.97 & 2.04 & 113 & 121. Bell pepper & 0.93 & 3.48 & 160 \\
\hline 60. Corned beef & 1.00 & 0.16 & 63 & 122. Carrots & 0.96 & 2.40 & 172 \\
\hline 61. Canned chicken & 1.02 & 0.70 & 47 & 123. Onion & 0.97 & 2.18 & 170 \\
\hline 62. Carp & 0.89 & 7.09 & 90 & 124. Maize & 0.82 & 7.65 & 92 \\
\hline
\end{tabular}


Table 7.1 Slope Coefficients, Cross-Country Regressions, 198 Food Items (continued)

\begin{tabular}{|c|c|c|c|c|c|c|c|}
\hline $\begin{array}{c}\text { Item } \\
(1) \\
\end{array}$ & $\begin{array}{c}\text { Slope } \\
(2)\end{array}$ & $\begin{array}{c}\text { t-stat } \\
(3)\end{array}$ & $\begin{array}{c}\text { Obs } \\
(4)\end{array}$ & $\begin{array}{c}\text { Item } \\
(5) \\
\end{array}$ & $\begin{array}{c}\text { Slope } \\
(6)\end{array}$ & $\begin{array}{c}\text { t-stat } \\
(7)\end{array}$ & $\begin{array}{c}\text { Obs } \\
(8) \\
\end{array}$ \\
\hline 125. Round tomato, loose & 0.88 & 7.21 & 169 & 162. Mayonnaise & 0.97 & 2.40 & 124 \\
\hline 126. Green cabbage & 0.93 & 3.51 & 119 & 163. Cooking salt & 1.00 & 0.09 & 162 \\
\hline 127. Lettuce & 0.91 & 5.86 & 158 & 164. Tomato ketchup & 1.02 & 1.67 & 166 \\
\hline 128. Avocado & 0.84 & 7.78 & 93 & 165. Black Pepper, ground & 0.92 & 4.55 & 144 \\
\hline 129. Eggplant (aubergine) & 0.87 & 6.72 & 163 & 166. Thin Soya Sauce & 0.93 & 3.51 & 148 \\
\hline 130. Cauliflower & 0.96 & 1.89 & 155 & 167. Curry Powder & 1.00 & 0.13 & 71 \\
\hline 131. Spinach & 0.86 & 5.80 & 131 & 168. Chicken Extract (bouillon/stock cube) & 0.92 & 4.46 & 117 \\
\hline 132. Chilies (Long) & 0.90 & 3.68 & 115 & 169. Baking powder & 0.96 & 2.70 & 102 \\
\hline 133. Ginger (Mature) & 0.97 & 1.40 & 80 & 170. Baby food & 0.98 & 1.19 & 117 \\
\hline 134. Garlic (White) & 0.98 & 1.22 & 134 & 171. Chili sauce & 1.02 & 0.80 & 75 \\
\hline 135. Brown Potatoes & 0.95 & 2.98 & 164 & 172. Chili powder & 1.00 & 0.01 & 81 \\
\hline 136. Sweet Potatoes & 0.81 & 9.47 & 110 & 173. Baby cereals & 0.99 & 0.76 & 152 \\
\hline 137. Cassava - Manioc - Yuka & 0.82 & 5.86 & 49 & 174. Cocoa Powder, Tin & 1.01 & 1.04 & 144 \\
\hline 138. Dried white beans & 0.96 & 2.63 & 100 & 175. Instant coffee [Specified brand] & 0.96 & 4.00 & 170 \\
\hline 139. Tinned white beans tomato sauce & 1.01 & 0.43 & 112 & 176. Coffee Roasted 100\% Arabica & 0.96 & 2.46 & 134 \\
\hline 140. Green Olives (with stones) & 1.00 & 0.07 & 136 & 177. Coffee Roasted $100 \%$ Robusta & 0.99 & 1.06 & 100 \\
\hline 141. Potato chips & 0.95 & 3.68 & 162 & 178. Tea bags, black & 0.98 & 1.87 & 160 \\
\hline 142. Frozen chipped potatoes & 1.03 & 2.53 & 120 & 179. Tea, green & 0.93 & 3.34 & 77 \\
\hline 143. Tomato paste (Small) & 0.95 & 3.86 & 155 & 180. Tea, black & 0.93 & 2.20 & 70 \\
\hline 144. Tomato paste (Large) & 1.03 & 2.43 & 59 & 181. Mineral water & 0.97 & 1.98 & 168 \\
\hline 145. Tinned green peas & 1.02 & 1.96 & 129 & 182. Carbonated Soft Drink (Small) & 0.98 & 1.69 & 166 \\
\hline 146. Tinned sweet corn/Maize & 1.06 & 5.28 & 139 & 183. Carbonated Soft Drink (Large) & 1.01 & 0.57 & 168 \\
\hline 147. Lentils, Dry & 1.01 & 0.67 & 132 & 184. Apple juice & 1.02 & 2.58 & 130 \\
\hline 148. Green/Mung Beans, dried & 0.96 & 3.00 & 30 & 185. Orange juice & 1.02 & 2.22 & 128 \\
\hline 149. Tinned Button Mushrooms & 1.05 & 2.90 & 73 & 186. Lemonade & 1.06 & 3.03 & 66 \\
\hline 150. White sugar & 0.99 & 1.17 & 161 & 187. Vodka & 0.95 & 3.19 & 154 \\
\hline 151. Brown sugar & 0.97 & 1.48 & 89 & 188. Whisky & 0.97 & 2.79 & 155 \\
\hline 152. Strawberry/Apricot Jam & 0.97 & 2.80 & 170 & 189. Gin [Specified Brand] & 0.98 & 1.98 & 97 \\
\hline 153. Pineapple Jam & 0.99 & 0.71 & 106 & 190. Irish whiskey \& cream liq. [Specified] & 1.01 & 0.60 & 55 \\
\hline 154. Orange marmalade & 1.00 & 0.33 & 116 & 191. Superior Light/White Rum & 0.96 & 2.79 & 125 \\
\hline 155. Natural honey, Mixed blossoms & 0.98 & 1.83 & 156 & 192. Red wine, table wine & 1.04 & 2.12 & 154 \\
\hline 156. Chocolate bar & 0.97 & 2.44 & 117 & 193. Red wine, Bordeaux Supérieur & 1.03 & 1.00 & 48 \\
\hline 157. Ice cream, Cornetto-type & 0.97 & 1.75 & 141 & 194. White wine, table wine & 1.03 & 1.29 & 127 \\
\hline 158. Chewing gum & 0.95 & 3.59 & 154 & 195. Sparkling wine & 0.98 & 1.39 & 131 \\
\hline 159. Fruit drops (Hard candies) & 0.94 & 4.03 & 135 & 196. Domestic Canned Beer & 0.97 & 2.48 & 130 \\
\hline 160. Ice cream, packed & 0.98 & 1.41 & 145 & 197. Domestic Beer Bottle & 0.94 & 5.16 & 151 \\
\hline 161. Toffee & 0.97 & 1.74 & 106 & 198. Beer [Specified brand] & 0.98 & 2.58 & 152 \\
\hline \multicolumn{8}{|l|}{ Summary statistics } \\
\hline Mean & 0.96 & 2.78 & 117 & & & & \\
\hline Median & 0.97 & 2.45 & 123 & & & & \\
\hline $\mathrm{SD}$ & 0.05 & 1.98 & 39 & & & & \\
\hline Min & 0.81 & 0.01 & 30 & & & & \\
\hline Max & 1.06 & 9.47 & 173 & & & & \\
\hline
\end{tabular}

Note: Food items are arranged in the order in which they appear in the ICP data. "Slope" refers to the estimated coefficient $\beta_{\mathrm{i}}$ and the $\mathrm{t}$-statistic is for $\mathrm{H}_{0}: \beta_{\mathrm{i}}=1$. "Obs" is the number of observations in each regression, that is, the number of countries $\mathrm{C}_{\mathrm{i}}$. 
Table 7.2 Slope Coefficients, Cross-Commodity Regressions, 175 Countries

$\log \mathrm{p}_{\mathrm{ic}}=\alpha_{\mathrm{c}}^{\prime}+\beta_{\mathrm{c}}^{\prime} \log \mathrm{p}_{\mathrm{i}}^{*}+\varepsilon_{\mathrm{ic}}^{\prime}, \mathrm{i}=1, \ldots, \mathrm{n}_{\mathrm{c}}$ food items consumed in $\mathrm{c} ; \mathrm{c}=1, \ldots, 175$ countries

\begin{tabular}{|c|c|c|c|c|c|c|c|}
\hline $\begin{array}{c}\text { Country } \\
\text { (1) }\end{array}$ & $\begin{array}{l}\text { Slope } \\
\text { (2) }\end{array}$ & $\begin{array}{c}\text { t-stat } \\
\text { (3) }\end{array}$ & $\begin{array}{l}\text { Obs } \\
(4)\end{array}$ & $\begin{array}{c}\text { Country } \\
\text { (5) }\end{array}$ & $\begin{array}{c}\text { Slope } \\
\text { (6) }\end{array}$ & $\begin{array}{c}\text { t-stat } \\
(7)\end{array}$ & $\begin{array}{c}\text { Obs } \\
(8)\end{array}$ \\
\hline 1. Bermuda & 0.70 & 4.76 & 118 & 63. Estonia & 1.01 & 0.36 & 124 \\
\hline 2. Cayman Islands & 0.76 & 4.17 & 127 & 64. Latvia & 1.00 & 0.03 & 125 \\
\hline 3. United States & 0.92 & 2.10 & 109 & 65. Uruguay & 0.82 & 3.97 & 86 \\
\hline 4. Hong Kong SAR, China & 1.00 & 0.10 & 134 & 66. Montenegro & 1.01 & 0.24 & 117 \\
\hline 5. Norway & 0.95 & 1.04 & 115 & 67. Kazakhstan & 1.02 & 0.58 & 155 \\
\hline 6. Luxembourg & 0.91 & 1.85 & 127 & 68. Mexico & 1.04 & 1.07 & 122 \\
\hline 7. Switzerland & 1.01 & 0.16 & 127 & 69. Mauritius & 0.98 & 0.31 & 146 \\
\hline 8. Taiwan, China & 0.98 & 0.61 & 130 & 70. Bulgaria & 0.97 & 0.74 & 131 \\
\hline 9. Singapore & 1.04 & 0.75 & 139 & 71. Malaysia & 0.96 & 0.94 & 151 \\
\hline 10. United Arab Emirates & 0.99 & 0.32 & 196 & 72. Grenada & 0.75 & 5.12 & 125 \\
\hline 11. Aruba & 0.78 & 4.47 & 130 & 73. Romania & 0.99 & 0.36 & 127 \\
\hline 12. Germany & 0.99 & 0.22 & 128 & 74. Panama & 0.81 & 3.89 & 118 \\
\hline 13. Sweden & 0.97 & 0.69 & 124 & 75. Serbia & 1.03 & 0.80 & 131 \\
\hline 14. Iceland & 1.00 & 0.06 & 116 & 76. Egypt, Arab Rep. & 1.12 & 2.18 & 153 \\
\hline 15. Austria & 0.94 & 1.24 & 122 & 77. Venezuela, RB & 0.82 & 2.62 & 108 \\
\hline 16. Australia & 0.90 & 2.25 & 117 & 78. Jordan & 1.16 & 3.56 & 189 \\
\hline 17. Denmark & 0.89 & 2.36 & 126 & 79. Ukraine & 1.04 & 1.17 & 149 \\
\hline 18. Macao SAR, China & 0.96 & 0.94 & 136 & 80. Brazil & 0.84 & 3.76 & 123 \\
\hline 19. Canada & 0.91 & 2.32 & 110 & 81. Virgin Islands, British & 0.62 & 6.60 & 103 \\
\hline 20. Finland & 0.98 & 0.39 & 110 & 82. Dominican Republic & 0.86 & 2.67 & 104 \\
\hline 21. France & 0.92 & 1.75 & 129 & 83. Armenia & 1.01 & 0.21 & 155 \\
\hline 22. Belgium & 0.97 & 0.65 & 128 & 84. Macedonia, FYR & 0.98 & 0.47 & 112 \\
\hline 23. United Kingdom & 0.99 & 0.30 & 130 & 85. Costa Rica & 0.91 & 1.93 & 116 \\
\hline 24. Netherlands & 1.02 & 0.40 & 120 & 86. Dominica & 0.80 & 3.31 & 114 \\
\hline 25. Curaçao & 0.74 & 5.35 & 128 & 87. St. Vincent and the Grenadines & 0.71 & 5.32 & 109 \\
\hline 26. Japan & 0.81 & 3.10 & 97 & 88. Thailand & 0.98 & 0.50 & 127 \\
\hline 27. Ireland & 0.93 & 1.54 & 130 & 89. Azerbaijan & 1.01 & 0.27 & 154 \\
\hline 28. Sint Maarten & 0.73 & 5.17 & 119 & 90. Belize & 0.87 & 2.22 & 115 \\
\hline 29. Cyprus & 0.94 & 1.92 & 127 & 91. St. Lucia & 0.83 & 3.17 & 122 \\
\hline 30. Italy & 0.95 & 1.32 & 132 & 92. Albania & 1.01 & 0.20 & 115 \\
\hline 31. New Zealand & 0.94 & 1.22 & 102 & 93. Colombia & 0.78 & 3.93 & 78 \\
\hline 32. Kuwait & 0.95 & 1.09 & 175 & 94. Bosnia and Herzegovina & 0.99 & 0.36 & 124 \\
\hline 33. Spain & 0.91 & 2.45 & 130 & 95. Algeria & 1.16 & 2.96 & 130 \\
\hline 34. Malta & 0.96 & 1.09 & 133 & 96. El Salvador & 0.86 & 2.41 & 111 \\
\hline 35. Greece & 0.98 & 0.54 & 133 & 97. South Africa & 0.87 & 2.90 & 130 \\
\hline 36. Israel & 1.02 & 0.65 & 121 & 98. Tunisia & 1.15 & 2.61 & 130 \\
\hline 37. Anguilla & 0.68 & 7.12 & 130 & 99. Sri Lanka & 1.02 & 0.35 & 114 \\
\hline 38. Korea, Rep. & 1.02 & 0.35 & 108 & 100. Peru & 0.91 & 1.92 & 110 \\
\hline 39. Bahrain & 0.99 & 0.30 & 187 & 101. Mongolia & 0.81 & 3.32 & 122 \\
\hline 40. Qatar & 0.96 & 0.90 & 168 & 102. Turks and Caicos Islands & 0.74 & 4.66 & 104 \\
\hline 41. St. Kitts and Nevis & 0.68 & 6.41 & 120 & 103. Jamaica & 0.79 & 4.72 & 132 \\
\hline 42. Portugal & 0.93 & 1.82 & 126 & 104. Ecuador & 1.02 & 0.34 & 69 \\
\hline 43. Slovenia & 0.94 & 1.61 & 129 & 105. Equatorial Guinea & 0.74 & 2.64 & 63 \\
\hline 44. Saudi Arabia & 0.96 & 0.94 & 180 & 106. Namibia & 0.83 & 3.77 & 181 \\
\hline 45. Trinidad and Tobago & 0.89 & 2.18 & 130 & 107. Moldova & 0.93 & 1.62 & 158 \\
\hline 46. Belarus & 1.07 & 1.30 & 133 & 108. Botswana & 0.82 & 4.73 & 149 \\
\hline 47. Bahamas, The & 0.67 & 6.16 & 109 & 109. Iraq & 1.09 & 2.17 & 157 \\
\hline 48. Brunei Darussalam & 0.92 & 1.44 & 131 & 110. Gabon & 0.89 & 2.27 & 167 \\
\hline 49. Czech Republic & 1.10 & 2.75 & 131 & 111. Guatemala & 0.89 & 2.66 & 127 \\
\hline 50. Lithuania & 1.01 & 0.17 & 125 & 112. Swaziland & 0.87 & 3.40 & 146 \\
\hline 51. Seychelles & 0.90 & 2.02 & 169 & 113. Paraguay & 0.83 & 3.45 & 121 \\
\hline 52. Poland & 1.10 & 2.79 & 129 & 114. Kyrgyzstan & 0.96 & 0.86 & 137 \\
\hline 53. Russian Federation & 1.07 & 1.52 & 110 & 115. Fiji & 0.99 & 0.33 & 102 \\
\hline 54. Slovakia & 1.03 & 0.88 & 124 & 116. Maldives & 0.75 & 3.44 & 86 \\
\hline 55. Montserrat & 0.54 & 7.17 & 108 & 117. Philippines & 0.94 & 1.51 & 146 \\
\hline 56. Antigua and Barbuda & 0.68 & 4.96 & 86 & 118. Indonesia & 1.03 & 0.74 & 139 \\
\hline 57. Turkey & 1.15 & 3.53 & 123 & 119. Palestinian Territory & 1.10 & 2.28 & 178 \\
\hline 58. Hungary & 1.00 & 0.05 & 126 & 120. Suriname & 0.77 & 4.72 & 133 \\
\hline 59. Barbados & 0.76 & 4.03 & 130 & 121. Morocco & 1.11 & 2.47 & 176 \\
\hline 60. Chile & 0.96 & 0.95 & 120 & 122. Cape Verde & 0.80 & 5.03 & 165 \\
\hline 61. Oman & 1.03 & 0.61 & 147 & 123. Nicaragua & 0.82 & 3.21 & 110 \\
\hline 62. Croatia & 0.94 & 1.56 & 130 & 124. China & 1.04 & 0.99 & 146 \\
\hline
\end{tabular}


Table 7.2 Slope Coefficients, Cross-Commodity Regressions, 175 Countries (continued) $\log \mathrm{p}_{\mathrm{ic}}=\alpha_{\mathrm{c}}^{\prime}+\beta_{\mathrm{c}}^{\prime} \log \mathrm{p}_{\mathrm{i}}^{*}+\varepsilon_{\mathrm{ic}}^{\prime}, \mathrm{i}=1, \ldots, \mathrm{n}_{\mathrm{c}}$ food items consumed in $\mathrm{c} ; \mathrm{c}=1, \ldots, 175$ countries

\begin{tabular}{|c|c|c|c|c|c|c|c|}
\hline $\begin{array}{c}\text { Country } \\
\text { (1) }\end{array}$ & $\begin{array}{c}\text { Slope } \\
(2)\end{array}$ & $\begin{array}{c}\text { t-stat } \\
\text { (3) }\end{array}$ & $\begin{array}{l}\text { Obs } \\
(4)\end{array}$ & $\begin{array}{c}\text { Country } \\
(5)\end{array}$ & $\begin{array}{c}\text { Slope } \\
(6)\end{array}$ & $\begin{array}{c}\text { t-stat } \\
(7)\end{array}$ & $\begin{array}{c}\text { Obs } \\
(8)\end{array}$ \\
\hline 125. Tajikistan & 1.05 & 1.21 & 125 & 151. Haiti & 0.80 & 1.80 & 47 \\
\hline 126. Vietnam & 1.05 & 1.16 & 128 & 152. Zambia & 0.87 & 2.71 & 147 \\
\hline 128. Bhutan & 1.02 & 0.34 & 103 & 154. Sierra Leone & 0.87 & 2.72 & 166 \\
\hline 129. Bolivia & 0.90 & 2.19 & 112 & 155. Gambia, The & 0.88 & 2.63 & 169 \\
\hline 130. Pakistan & 1.04 & 0.78 & 113 & 156. Chad & 0.92 & 1.50 & 102 \\
\hline 131. Honduras & 0.86 & 2.60 & 105 & 157. Togo & 0.93 & 1.45 & 168 \\
\hline 132. Myanmar & 1.01 & 0.16 & 115 & 158. Rwanda & 1.00 & 0.08 & 150 \\
\hline 133. Yemen & 0.94 & 0.96 & 132 & 159. Benin & 0.88 & 2.24 & 134 \\
\hline 134. São Tomé and Principe & 0.91 & 2.01 & 147 & 160. Madagascar & 0.83 & 3.40 & 170 \\
\hline 135. India & 0.99 & 0.24 & 160 & 161. Zimbabwe & 0.85 & 4.10 & 172 \\
\hline 136. Lao PDR & 0.93 & 1.11 & 104 & 162. Malawi & 0.84 & 3.14 & 154 \\
\hline 137. Cambodia & 0.98 & 0.55 & 133 & 163. Ethiopia & 1.08 & 1.59 & 134 \\
\hline 138. Ghana & 0.79 & 5.33 & 184 & 164. Guinea-Bissau & 0.82 & 4.45 & 178 \\
\hline 139. Bangladesh & 1.15 & 3.02 & 124 & 165. Mali & 0.85 & 3.17 & 175 \\
\hline 141. Nigeria & 0.73 & 6.95 & 183 & 167. Guinea & 0.99 & 0.11 & 122 \\
\hline 142. Sudan & 0.81 & 3.33 & 125 & 168. Tanzania & 0.88 & 2.60 & 158 \\
\hline 143. Kenya & 1.02 & 0.41 & 143 & 169. Mozambique & 0.88 & 2.97 & 176 \\
\hline 144. Nepal & 1.14 & 2.89 & 97 & 170. Burkina Faso & 0.95 & 0.82 & 124 \\
\hline 145. Djibouti & 0.97 & 0.53 & 153 & 171. Central African Republic & 0.83 & 2.92 & 137 \\
\hline 146. Côte d'Ivoire & 0.92 & 1.63 & 175 & 172. Comoros & 0.84 & 2.77 & 124 \\
\hline 147. Senegal & 0.88 & 2.76 & 161 & 173. Burundi & 1.06 & 0.99 & 146 \\
\hline 148. Cameroon & 0.89 & 2.39 & 176 & 174. Niger & 0.92 & 1.48 & 134 \\
\hline 149. Mauritania & 0.85 & 2.69 & 122 & 175. Congo, Dem. Rep. & 0.89 & 2.40 & 168 \\
\hline 150. Uganda & 1.03 & 0.63 & 168 & & & & \\
\hline \multicolumn{8}{|l|}{ Summary statistics } \\
\hline Mean & 0.92 & 2.15 & 132 & & & & \\
\hline Median & 0.93 & 1.92 & 129 & & & & \\
\hline $\mathrm{SD}$ & 0.11 & 1.66 & 26 & & & & \\
\hline Min & 0.54 & 0.03 & 47 & & & & \\
\hline Max & 1.16 & 7.17 & 196 & & & & \\
\hline
\end{tabular}

Note: Countries are arranged by decreasing GDP per capita. "Slope" refers to the estimated coefficient $\beta_{\mathrm{c}}^{\prime}$ and the t-statistic is for

$\mathrm{H}_{0}: \beta_{\mathrm{c}}^{\prime}=1$. "Obs" is the number of observations in each regression, that is, the number of items $n_{c}$. 
Table 9.1 Law of One Price Deviations, Variance Decompositions

\begin{tabular}{|c|c|c|c|c|c|}
\hline \multirow{3}{*}{ Year } & \multirow{3}{*}{$\begin{array}{l}\text { Grand standard } \\
\text { deviation }\end{array}$} & \multicolumn{2}{|c|}{$\begin{array}{l}\text { Commodity decomposition } \\
\text { (Percentages of total) }\end{array}$} & \multicolumn{2}{|c|}{$\begin{array}{l}\text { Country decomposition } \\
\text { (Percentages of total) }\end{array}$} \\
\hline & & Cross-country & Cross-commodity & Cross-country & Cross-commodity \\
\hline & & $\frac{\theta_{\text {Cross }-}^{2}}{\text { county }} \times 100$ & $\frac{\theta_{\text {Cross- }}^{2}}{\sigma^{2}} \times 100$ & $\frac{\phi_{\text {Crosss- }}^{2}}{\text { country }^{2}} \times 100$ & $\frac{\phi_{\text {Cross- }}^{2}}{\sigma^{2}} \times 100$ \\
\hline (1) & (2) & (3) & (4) & (5) & (6) \\
\hline 1991 & 1.01 & 63.9 & 36.1 & 53.7 & 46.3 \\
\hline 1992 & 1.01 & 69.6 & 30.4 & 52.9 & 47.1 \\
\hline 1993 & 0.97 & 67.2 & 32.8 & 47.3 & 52.7 \\
\hline 1994 & 1.13 & 73.1 & 26.9 & 62.5 & 37.5 \\
\hline 1995 & 0.94 & 65.6 & 34.4 & 39.3 & 60.7 \\
\hline 1996 & 0.88 & 67.2 & 32.8 & 39.1 & 60.9 \\
\hline 1997 & 0.89 & 68.1 & 31.9 & 35.7 & 64.3 \\
\hline 1998 & 0.91 & 68.1 & 31.9 & 37.9 & 62.1 \\
\hline 1999 & 0.92 & 67.6 & 32.4 & 33.2 & 66.8 \\
\hline 2000 & 0.91 & 68.7 & 31.3 & 32.0 & 68.0 \\
\hline 2001 & 0.90 & 68.9 & 31.1 & 32.0 & 68.0 \\
\hline 2002 & 0.90 & 67.4 & 32.6 & 31.7 & 68.3 \\
\hline 2003 & 0.90 & 69.7 & 30.3 & 32.6 & 67.4 \\
\hline 2004 & 0.88 & 67.9 & 32.1 & 32.1 & 67.9 \\
\hline 2005 & 0.87 & 69.8 & 30.2 & 32.0 & 68.0 \\
\hline 2006 & 0.89 & 67.4 & 32.6 & 32.3 & 67.7 \\
\hline 2007 & 0.84 & 67.0 & 33.0 & 32.6 & 67.4 \\
\hline 2008 & 0.83 & 66.9 & 33.1 & 33.0 & 67.0 \\
\hline 2009 & 0.85 & 67.0 & 33.0 & 29.6 & 70.4 \\
\hline 2010 & 0.94 & 67.5 & 32.5 & 53.6 & 46.4 \\
\hline 2011 & 0.93 & 66.7 & 33.3 & 57.1 & 42.9 \\
\hline 2012 & 0.90 & 68.3 & 31.7 & 57.2 & 42.8 \\
\hline 2013 & 0.80 & 70.4 & 29.6 & 37.4 & 62.6 \\
\hline Mean & 0.91 & 68.0 & 32.0 & 40.3 & 59.7 \\
\hline SD & 0.07 & 1.8 & 1.8 & 10.2 & 10.2 \\
\hline
\end{tabular}

Notes: See text for details. 
Table 10.1 Panel Unit Root Tests, 124 Food and Agriculture Items, 1991-2013

\begin{tabular}{|c|c|c|c|c|c|c|c|}
\hline $\begin{array}{c}\text { Item } \\
(1)\end{array}$ & $\begin{array}{l}\text { Obs } \\
\text { (2) }\end{array}$ & $\begin{array}{c}Z^{*} \text {-stat } \\
\text { (3) }\end{array}$ & $\begin{array}{c}\text { p-value } \\
\text { (4) }\end{array}$ & $\begin{array}{c}\text { Item } \\
(5)\end{array}$ & $\begin{array}{c}\text { Obs } \\
(6)\end{array}$ & $\begin{array}{c}Z^{*} \text {-stat } \\
\text { (7) }\end{array}$ & $\begin{array}{c}\text { p-value } \\
\text { (8) }\end{array}$ \\
\hline 1. Anise, badian, fennel, coriander & 46 & -1.94 & 0.03 & 51. Kiwi fruit & 157 & -1.18 & 0.12 \\
\hline 2. Apples & 1,307 & -5.68 & 0.00 & 52. Leeks, other alliaceous vegetables & 242 & -3.83 & 0.00 \\
\hline 3. Apricots & 751 & -7.91 & 0.00 & 53. Lemons and limes & 826 & -4.48 & 0.00 \\
\hline 4. Artichokes & 277 & -1.37 & 0.09 & 54. Lentils & 546 & -3.7 & 0.00 \\
\hline 5. Asparagus & 406 & -2.64 & 0.00 & 55. Lettuce and chicory & 955 & -4.21 & 0.00 \\
\hline 6. Avocados & 489 & -3.89 & 0.00 & 56. Linseed & 320 & -2.02 & 0.02 \\
\hline 7. Bananas & 962 & -4.35 & 0.00 & 57. Maize & 2,044 & -7.6 & 0.00 \\
\hline 8. Barley & 1,484 & -3.35 & 0.00 & 58. Maize, green & 220 & -2.51 & 0.01 \\
\hline 9. Beans, dry & 1,241 & -5.28 & 0.00 & 59. Mangoes, mangosteens, guavas & 507 & -2.63 & 0.00 \\
\hline 10. Beans, green & 960 & -3.44 & 0.00 & 60. Meat, cattle & 1,339 & -3.97 & 0.00 \\
\hline 11. Beeswax & 127 & 0.94 & 0.83 & 61. Meat, chicken & 1,319 & -4.1 & 0.00 \\
\hline 12. Blueberries & 82 & -1.03 & 0.15 & 62. Meat, duck & 260 & -3.02 & 0.00 \\
\hline 13. Broad beans, horse beans, dry & 359 & -4.77 & 0.00 & 63. Meat, game & 66 & -3.35 & 0.00 \\
\hline 14. Buckwheat & 219 & -4.45 & 0.00 & 64. Meat, goat & 816 & -0.86 & 0.19 \\
\hline 15. Cabbages and other brassicas & 1,715 & -5.56 & 0.00 & 65. Meat, goose and guinea fowl & 125 & -3.05 & 0.00 \\
\hline 16. Canary seed & 98 & -2.8 & 0.00 & 66. Meat, horse & 283 & -0.19 & 0.43 \\
\hline 17. Carrots and turnips & 1,643 & -4.87 & 0.00 & 67. Meat, pig & 1,334 & -5.1 & 0.00 \\
\hline 18. Cashew nuts, with shell & 207 & -2.85 & 0.00 & 68. Meat, rabbit & 273 & -3.33 & 0.00 \\
\hline 19. Cauliflowers and broccoli & 991 & -5.03 & 0.00 & 69. Meat, sheep & 1,212 & -4.11 & 0.00 \\
\hline 20. Cherries & 864 & -3.49 & 0.00 & 70. Meat, turkey & 322 & -1.36 & 0.09 \\
\hline 21. Cherries, sour & 399 & -4.51 & 0.00 & 71. Melons, other (inc.cantaloupes) & 720 & -4.3 & 0.00 \\
\hline 22. Chestnut & 177 & -0.74 & 0.23 & 72. Milk, whole fresh cow & 1,981 & -2.43 & 0.01 \\
\hline 23. Chick peas & 458 & -2.85 & 0.00 & 73. Millet & 591 & -2.93 & 0.00 \\
\hline 24. Chillies and peppers, dry & 138 & -0.23 & 0.41 & 74. Mushrooms and truffles & 546 & -1.47 & 0.07 \\
\hline 25. Chillies and peppers, green & 1,035 & -3.75 & 0.00 & 75. Mustard seed & 189 & -3.29 & 0.00 \\
\hline 26. Cloves & 43 & -0.09 & 0.46 & 76. Nutmeg, mace and cardamoms & 62 & -0.01 & 0.50 \\
\hline 27. Cocoa, beans & 414 & -4.65 & 0.00 & 77. Nuts, nes & 101 & -3.13 & 0.00 \\
\hline 28. Coconuts & 404 & -0.62 & 0.27 & 78. Oats & 1,164 & -7.77 & 0.00 \\
\hline 29. Coffee, green & 637 & -4.2 & 0.00 & 79. Oil, palm & 187 & -2.91 & 0.00 \\
\hline 30. Cotton lint & 204 & -4.34 & 0.00 & 80. Oilseeds nes & 55 & -0.69 & 0.25 \\
\hline 31. Cottonseed & 223 & -1.66 & 0.05 & 81. Olives & 466 & -0.83 & 0.20 \\
\hline 32. Cranberries & 46 & -1.31 & 0.10 & 82. Onions, dry & 1,623 & -9.93 & 0.00 \\
\hline 33. Cucumbers and gherkins & 1,583 & -4.66 & 0.00 & 83. Onions, shallots, green & 534 & -2.95 & 0.00 \\
\hline 34. Currants & 267 & -2.01 & 0.02 & 84. Oranges & 1,174 & -4.47 & 0.00 \\
\hline 35. Dates & 256 & -1.64 & 0.05 & 85. Papayas & 439 & -1.94 & 0.03 \\
\hline 36. Eggplants (aubergines) & 666 & -4.73 & 0.00 & 86. Peaches and nectarines & 857 & -4.5 & 0.00 \\
\hline 37. Eggs, hen, in shell & 2,058 & -5.72 & 0.00 & 87. Pears & 1,080 & -5.24 & 0.00 \\
\hline 38. Eggs, other bird, in shell & 55 & -4.76 & 0.00 & 88. Peas, dry & 730 & -2.1 & 0.02 \\
\hline 39. Figs & 424 & -3.08 & 0.00 & 89. Peas, green & 837 & -3.27 & 0.00 \\
\hline 40. Flax fibre and tow & 176 & -0.74 & 0.23 & 90. Pepper (piper spp.) & 203 & -1.67 & 0.05 \\
\hline 41. Fruit, fresh nes & 228 & -2.98 & 0.00 & 91. Persimmons & 62 & -0.87 & 0.19 \\
\hline 42. Garlic & 1,076 & -4.84 & 0.00 & 92. Pineapples & 658 & -1.21 & 0.11 \\
\hline 43. Ginger & 283 & -4 & 0.00 & 93. Pistachios & 137 & -4.26 & 0.00 \\
\hline 44. Gooseberries & 154 & 0.04 & 0.51 & 94. Plantains & 489 & -3.89 & 0.00 \\
\hline 45. Grain, mixed & 39 & -3.23 & 0.00 & 95. Plums and sloes & 922 & -6.43 & 0.00 \\
\hline 46. Grapefruit (inc. pomelos) & 526 & -2.09 & 0.02 & 96. Poppy seed & 105 & -2.55 & 0.01 \\
\hline 47. Grapes & 1,141 & -1.49 & 0.07 & 97. Potatoes & 2,139 & -3.46 & 0.00 \\
\hline 48. Honey, natural & 1,102 & -2.67 & 0.00 & 98. Pumpkins, squash and gourds & 822 & -4.69 & 0.00 \\
\hline 49. Hops & 273 & -2.27 & 0.01 & 99. Quinces & 387 & -1.81 & 0.04 \\
\hline 50. Jute & 126 & -0.39 & 0.35 & 100. Rapeseed & 740 & -6.17 & 0.00 \\
\hline
\end{tabular}


Table 10.1 Panel Unit Root Tests, 124 Food and Agriculture Items, 1991-2013 (continued)

\begin{tabular}{|c|c|c|c|c|c|c|c|}
\hline $\begin{array}{c}\text { Item } \\
\text { (1) }\end{array}$ & $\begin{array}{l}\text { Obs } \\
\text { (2) }\end{array}$ & $\begin{array}{c}Z^{*} \text {-stat } \\
\text { (3) }\end{array}$ & $\begin{array}{c}\text { p-value } \\
\text { (4) }\end{array}$ & $\begin{array}{c}\text { Item } \\
\text { (5) }\end{array}$ & $\begin{array}{c}\text { Obs } \\
(6)\end{array}$ & $\begin{array}{c}\text { Z*-stat } \\
\text { (7) }\end{array}$ & $\begin{array}{c}\mathrm{p} \text {-value } \\
\text { (8) }\end{array}$ \\
\hline 101. Roots and tubers, nes & 142 & -2.15 & 0.02 & 116. Tobacco, unmanufactured & 1,121 & -1.93 & 0.03 \\
\hline 102. Rubber, natural & 193 & -0.61 & 0.27 & 117. Tomatoes & 2,094 & -5.85 & 0.00 \\
\hline 103. Rye & 843 & -3.34 & 0.00 & 118. Triticale & 318 & -2.86 & 0.00 \\
\hline 104. Sesame seed & 524 & -1.59 & 0.06 & 119. Vanilla & 63 & -1.04 & 0.15 \\
\hline 105. Silk-worm cocoons, reelable & 129 & -0.86 & 0.20 & 120. Vegetables, fresh nes & 421 & -3.68 & 0.00 \\
\hline 106. Sorghum & 973 & -4.09 & 0.00 & 121. Walnuts, with shell & 540 & -4.16 & 0.00 \\
\hline 107. Soybeans & 1,054 & -3.39 & 0.00 & 122. Watermelons & 969 & -5.63 & 0.00 \\
\hline 108. Spices, nes & 54 & -3.58 & 0.00 & 123. Wheat & 1,720 & -3.97 & 0.00 \\
\hline 109. Spinach & 642 & -5.04 & 0.00 & 124. Wool, greasy & 851 & -5.06 & 0.00 \\
\hline 110. Strawberries & 1,002 & -3.82 & 0.00 & Summary statistics & & & \\
\hline 111. Sugar beet & 847 & -1.33 & 0.09 & Mean & 639 & -3.24 & 0.06 \\
\hline 112. Sunflower seed & 793 & -8.97 & 0.00 & Median & 516 & -3.28 & 0.00 \\
\hline 113. Sweet potatoes & 930 & -2.41 & 0.01 & SD & 516 & 1.89 & 0.13 \\
\hline 114. Tanger., manda., clemens, satsumas & 599 & -4.1 & 0.00 & Min & 39 & -9.93 & 0.00 \\
\hline 115. Tea & 367 & -2.47 & 0.01 & Max & 2,139 & 1.89 & 0.83 \\
\hline
\end{tabular}

Notes: The panels are unbalanced and "Obs" denotes the total number of non-missing country-year observations for each commodity. We exclude commodities with less than two producing countries and less than a total of 30 country-year observations. The $Z^{*}$-stat is the inverse-normal statistic that tests $\mathrm{H}_{0}: \beta_{\text {ic }}=0 \forall \mathrm{c}$ in $\Delta \mathrm{k}_{\mathrm{ict}}=\alpha_{\mathrm{c}}+\beta_{\mathrm{c}} \mathrm{k}_{\mathrm{ic}, \mathrm{t}-1}+\sum_{\mathrm{p}=1}^{\mathrm{m}_{\mathrm{c}}} \phi_{\mathrm{cp}} \Delta \mathrm{k}_{\mathrm{ic}, \mathrm{t}-\mathrm{p}}+\varepsilon_{\mathrm{ict}}, \mathrm{c}=1, \ldots, \mathrm{C}_{\mathrm{i}}$ producing countries of commodity. Here, $\mathrm{k}_{\mathrm{ic}, \mathrm{t}}=\log \mathrm{p}_{\mathrm{ict}}-\log \mathrm{p}_{\mathrm{it}}^{*}-\log \mathrm{S}_{\mathrm{ct}}$, where $p_{i c t}$ is the price (in local currency units) of commodity $i$ in country $c$ in year $t, p_{i t}^{*}$ is the world price of $i$ (in $\$ U S$ ) and $S_{c t}$ is the exchange rate of $c$ (the domestic currency cost of \$US1). That is, $\mathrm{k}_{\mathrm{ict}}$ is the logarithmic deviation from the LOP. See text for further details.

Figure 2.1 Food Consumption and Incomes, 155 countries in 2011

Food budget share $\times 100$

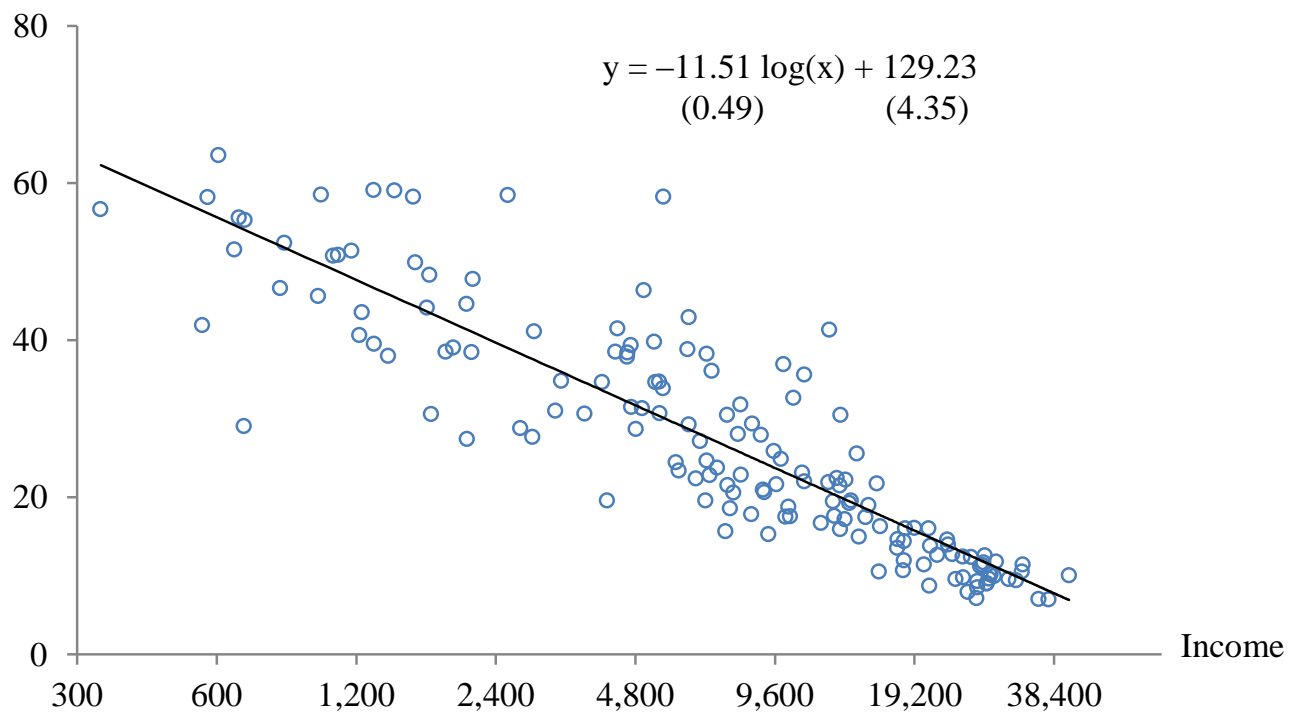

Note: The food budget share is the proportion of total consumption devoted to food. Income (total consumption) is in \$US per capita, as in the note to Table 2.1. The equation is for a regression of the food share on the logarithm of income. Standard errors in parentheses. 
Figure 2.2 Food Prices and Incomes, 155 countries in 2011

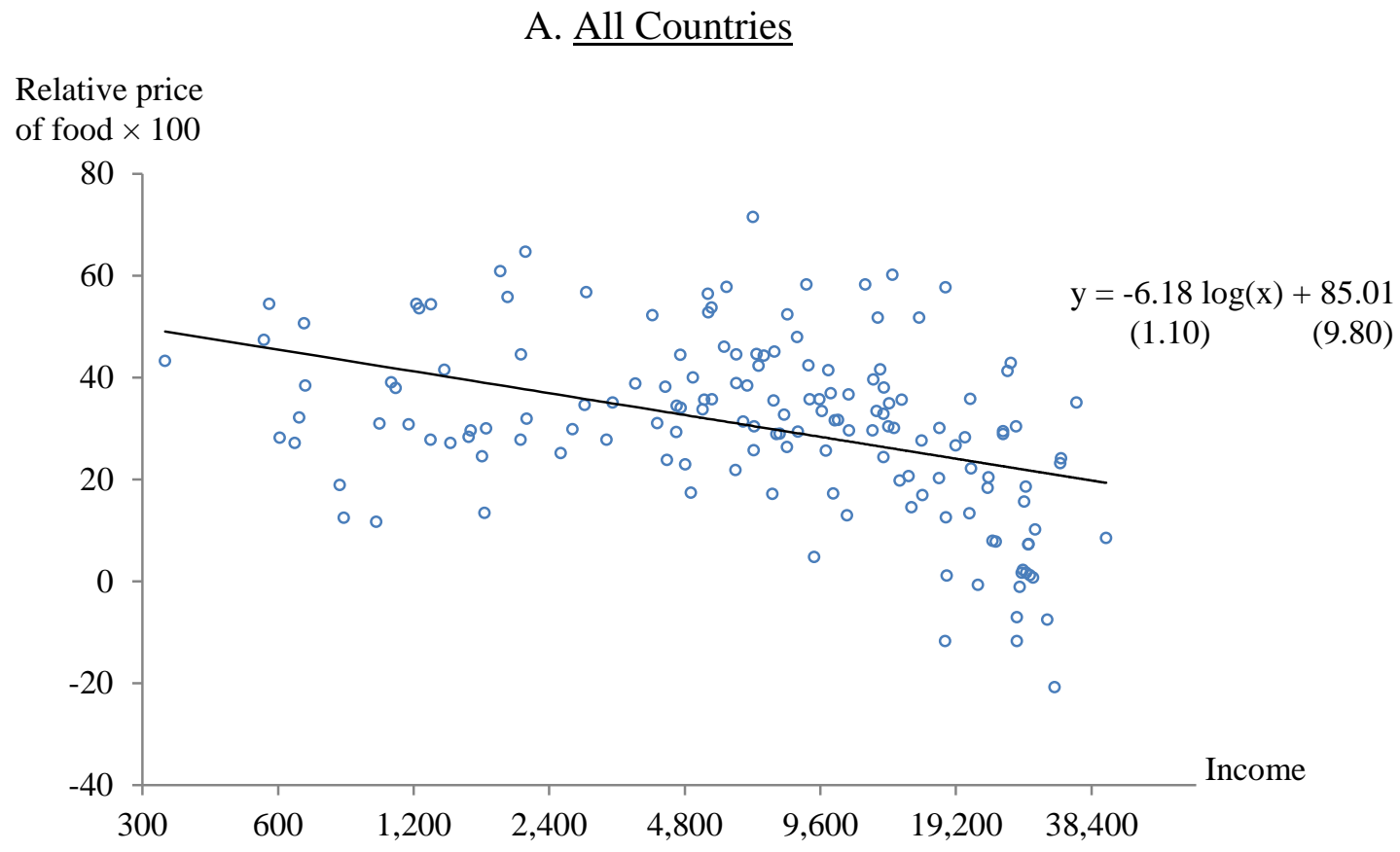

\section{B. Income Quartiles}

Relative price

of food $\times 100$

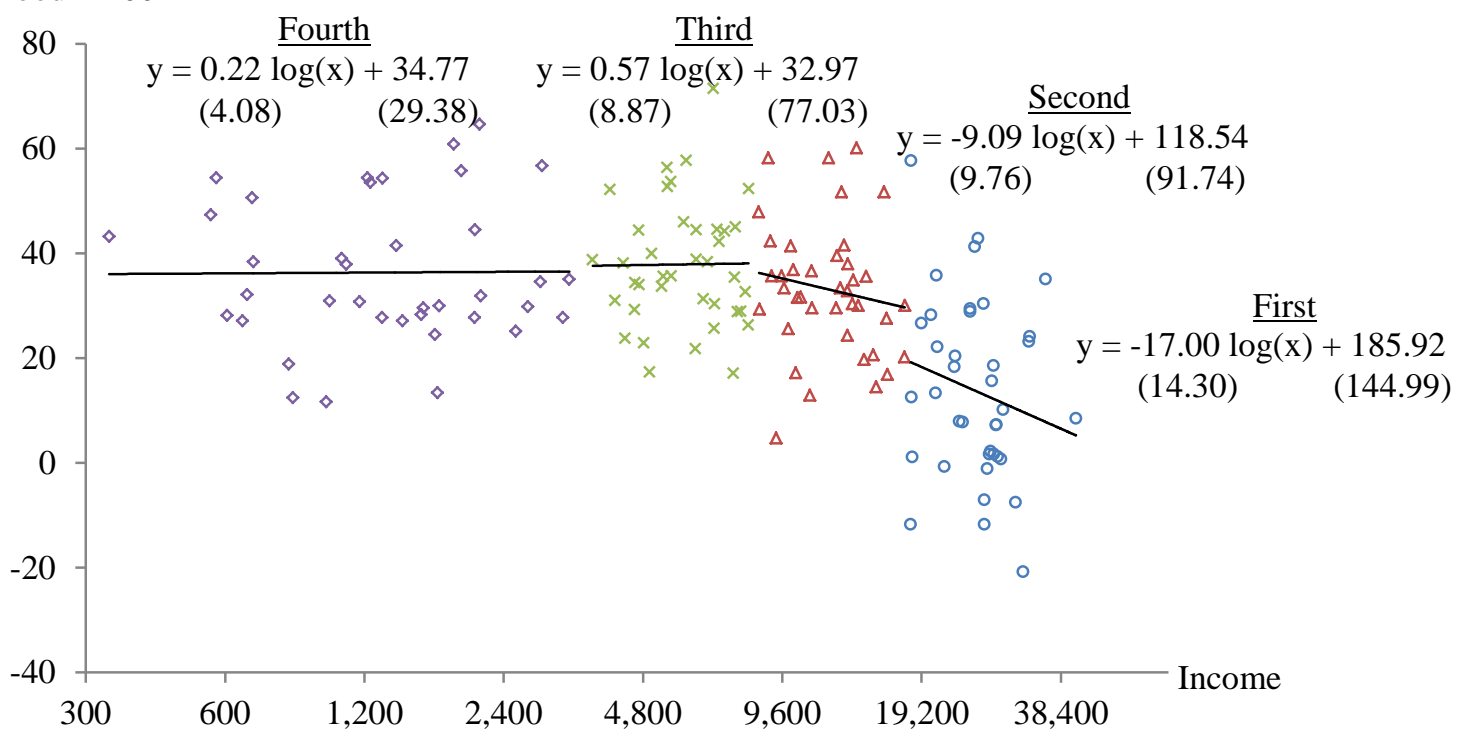

Note: The relative price of food is $\log \left(\mathrm{P}_{\mathrm{F}} / \mathrm{P}\right)=\log \mathrm{P}_{\mathrm{F}}-\log \mathrm{P}$, the difference between the conditional budget-share weighted $\log$ arithmic mean of the prices of the food items, $\log \mathrm{P}_{\mathrm{F}}$, and the $\log$ of the cost-of-living index, $\log \mathrm{P}$. Income (total consumption) is in \$US per capita, as in the note to Table 2.1. The solid line is the regression line. The equation is for a regression of the relative price of food on the logarithm of income.The US, the base country, is excluded. Standard errors in parentheses. 


\section{Figure 3.1 Food Price Dispersion and Incomes}

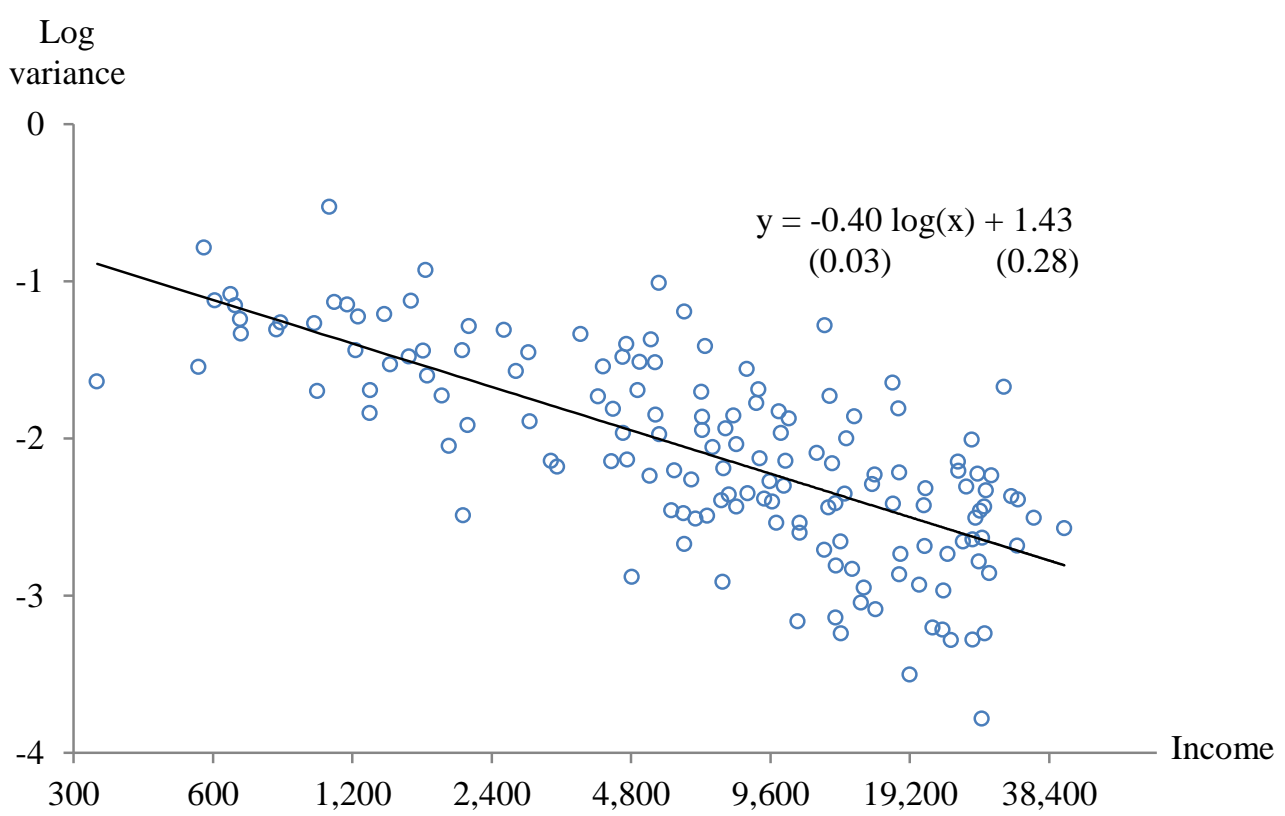

Notes: The variance of the 31 food prices is $\Pi_{F}=\Sigma_{i=1}^{31} w_{i}^{\prime}\left(\log p_{i}-\log P_{F}\right)^{2}$, where $w_{i}^{\prime}$ is the proportion of food expenditure devoted to item $\mathrm{i}$ and $\log \mathrm{P}_{\mathrm{F}}=\Sigma_{\mathrm{i}=1}^{31} \mathrm{w}_{\mathrm{i}}^{\prime} \log \mathrm{p}_{\mathrm{i}}$ is an index of the price of food. Income (total consumption) is in \$US per capita, as in the note to Table 2.1. The solid line is the regression line. The equation is for a regression of the logarithm of the variance on the logarithm of income. Standard errors in parentheses.

Figure 5.1 When is a Good Traded?

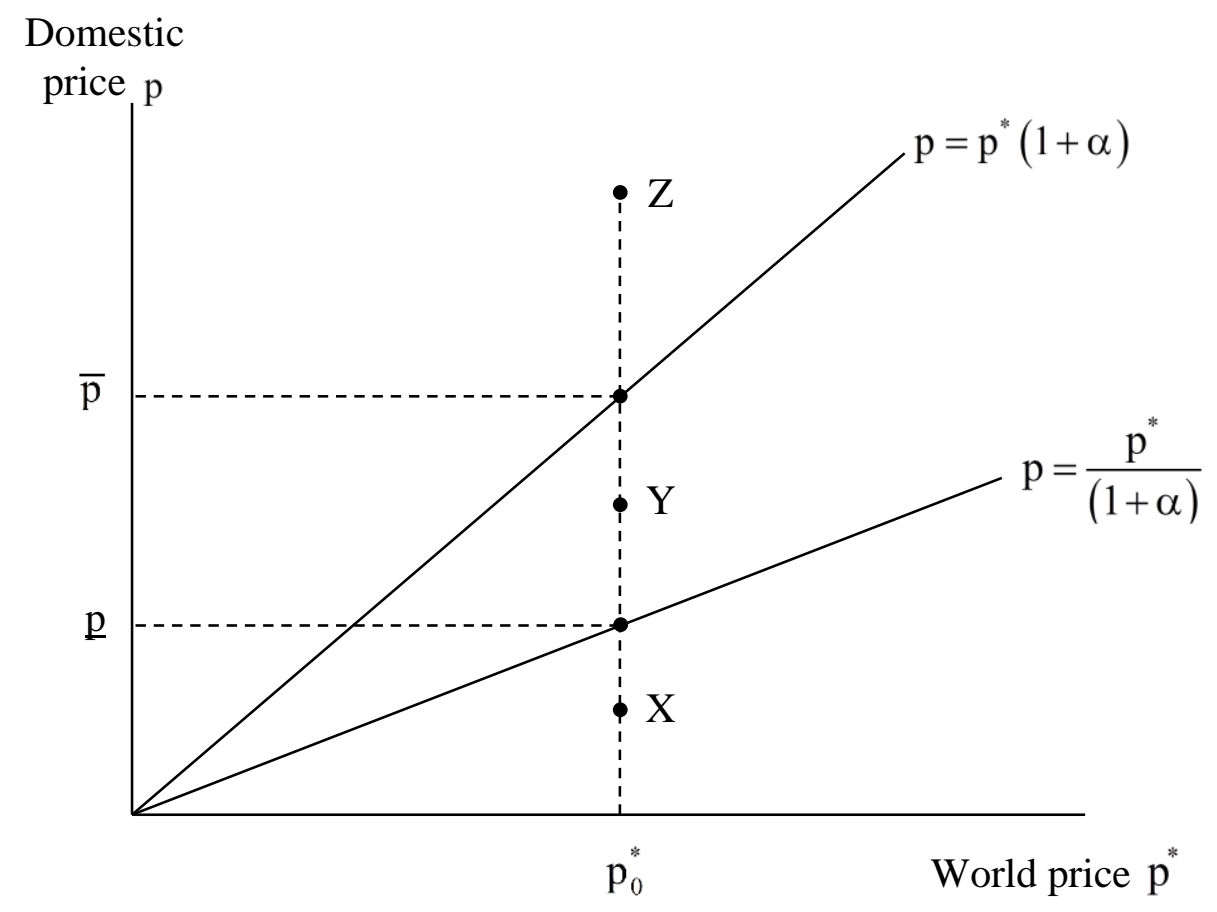


Figure 5.2 Cross-Country Box Plots and Standard Deviations
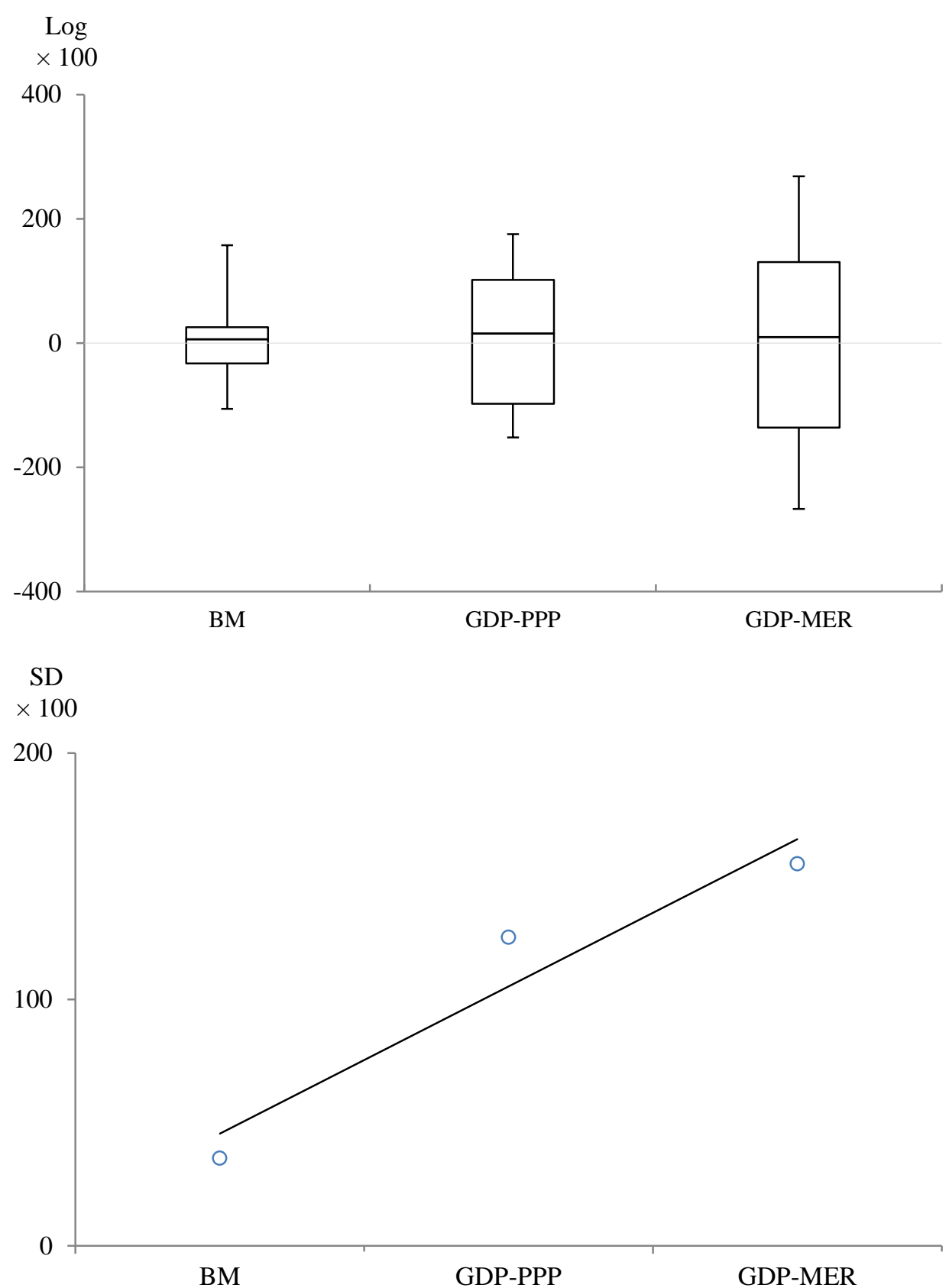

Notes: The Big Mac (BM) prices are for 57 countries, refer to 2011 and are in \$US; these are logged and demeaned. GDPs are per capita, are for 175 countries and defined similarly to the BM prices (that is, they also refer to 2011, are in \$US, logged and demeaned). The standard deviation of (the logs of) BM prices is 0.35; GDP-PPP, 1.25; and GDP-MER, 1.55.

Source: Market exchange rates for Big Macs are from The Economist (http://www.economist.com/content/big-macindex), whilst the PPP and market exchange rates for GDP p.c. are from the ICP spreadsheet (World Bank, unpublished). Though similar, the two versions of the market exchange rate vary slightly due to different measurement horizon. 
Figure 5.3 Distributions of Three Items Globally

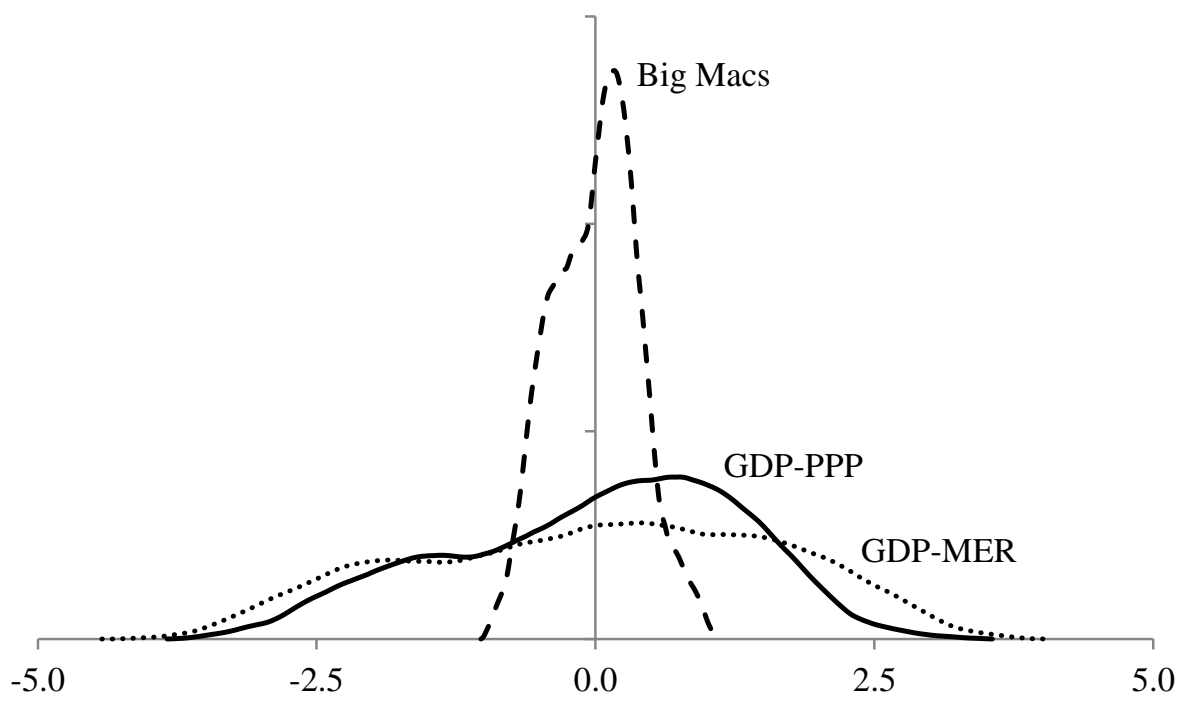

Notes: These are kernel densities of the Epanechnikov form. Items are logged and demeaned. See note to Figure 5.2 
Figure 5.4 Prices and Exchange Rates:Three Illustrations
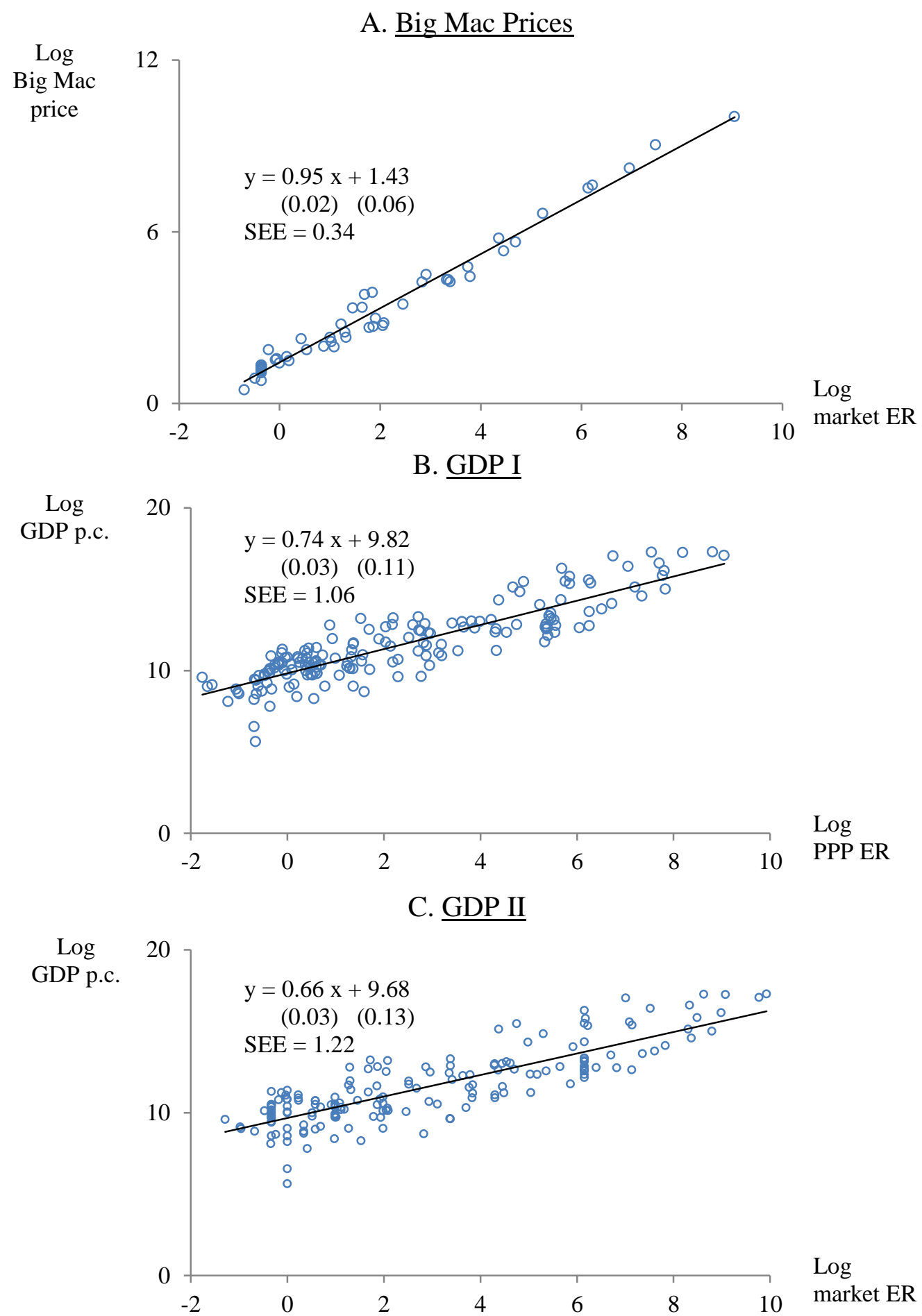

Notes:

1. Panel A: This is a scatter of the log of Big Mac prices for 57 countries in 2011 in local currency units (LCUs) against the log of market exchange rates (Ers). The solid line is the OLS regression line. Standard errors are in parentheses. SEE is the standard error of the regression.

2. Panels B and C: These are scatters of the log of GDP per capita for 175 countries in 2011 in LCUs against the $\log$ of the PPP Ers from the ICP (panel B) and the market Ers (panel C). 
Figure 6.1 Distribution of Real Relative Prices, 198 commodities in 175 countries in 2011

\section{Histogram}

\section{Cumulative distribution}

A. All commodities and countries
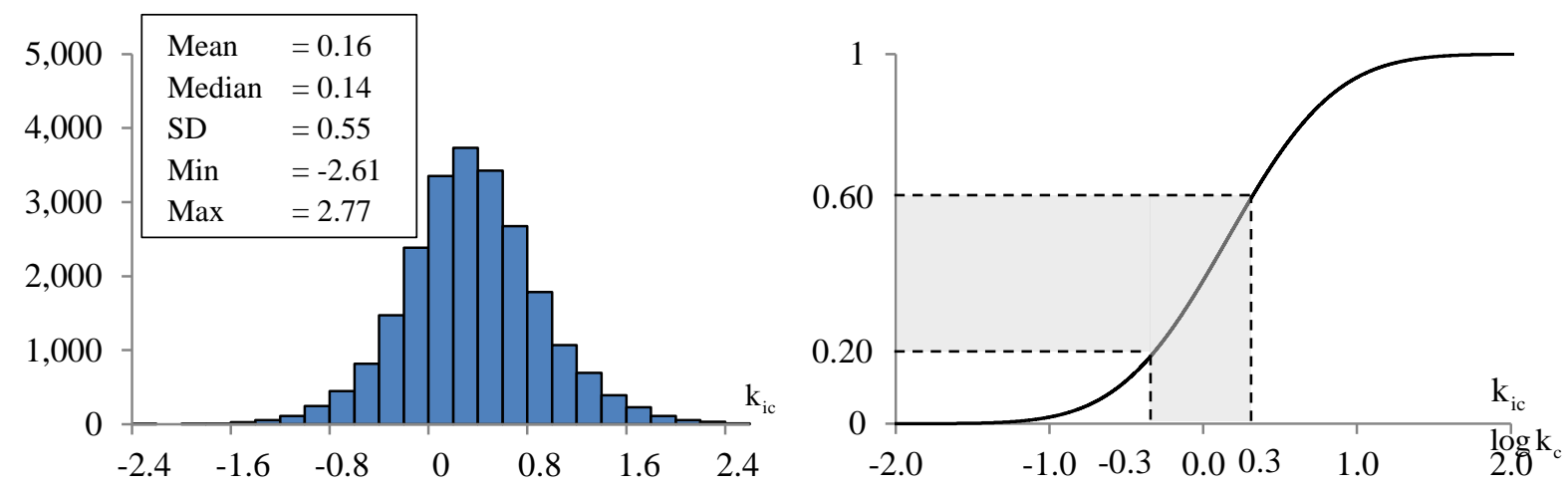

\section{B. Country means}
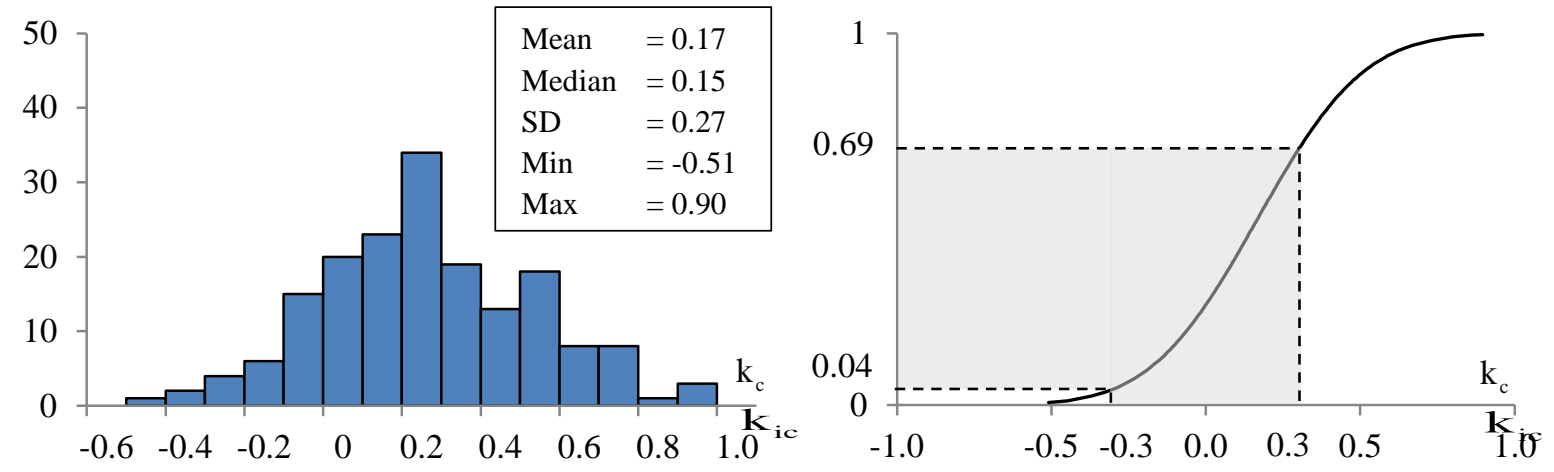

\section{Commodity means}
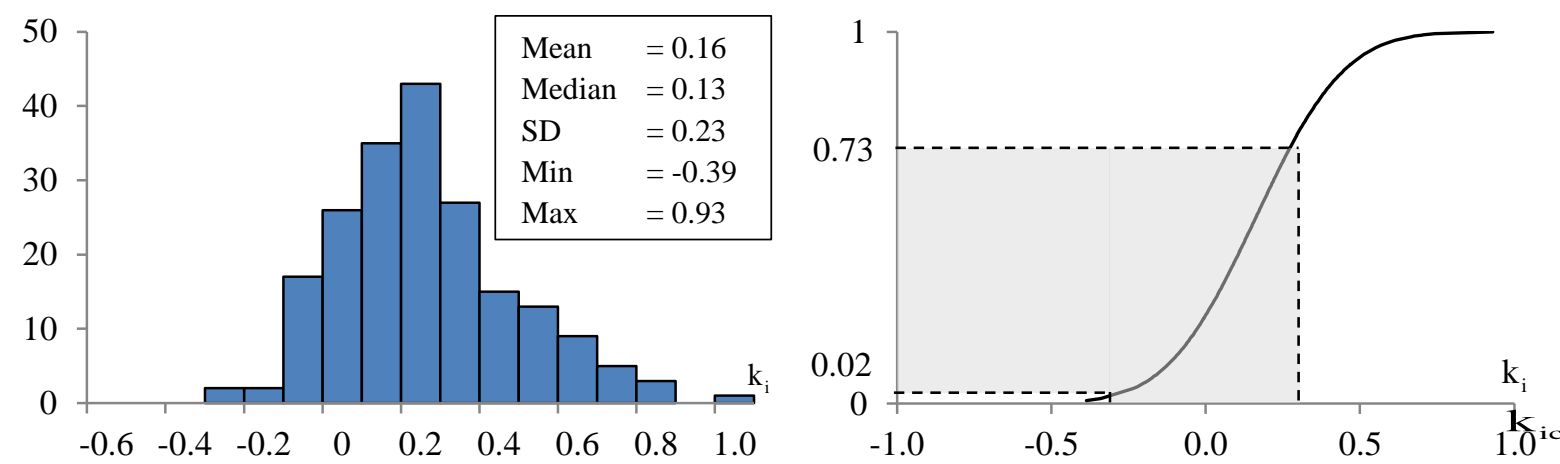

Note: The "real relative" price of commodity i in country c compares the domestic price $\left(p_{i c}\right)$ with the world price $\left(\mathrm{p}_{\mathrm{i}}^{*}\right)$, after adjusting for differing currencies via the exchange rate $\left(\mathrm{S}_{\mathrm{c}}\right)$. The measure is expressed in $\operatorname{logarithmic}$ form as $\mathrm{k}_{\mathrm{ic}}=\log \mathrm{p}_{\mathrm{ic}}-\log \mathrm{p}_{\mathrm{i}}^{*}-\log \mathrm{S}_{\mathrm{c}}$, which is 0 when prices coincide, and is positive (negative) when the domestic price is above (below) the world price. The country (commodity) means are across commodities (countries). 
Figure 6.2 Box Plots of Real Relative Prices,

Selected Commodities and Countries

\section{A. Commodities}

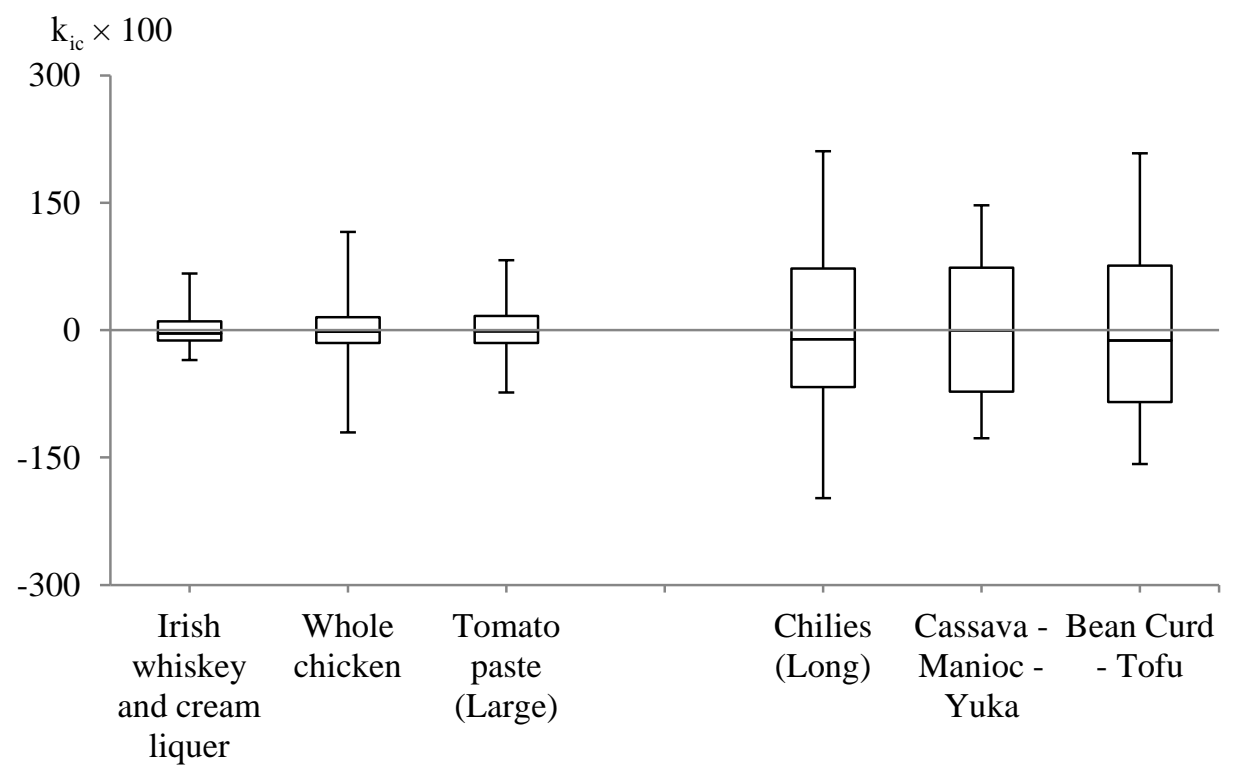

\section{B. Countries}

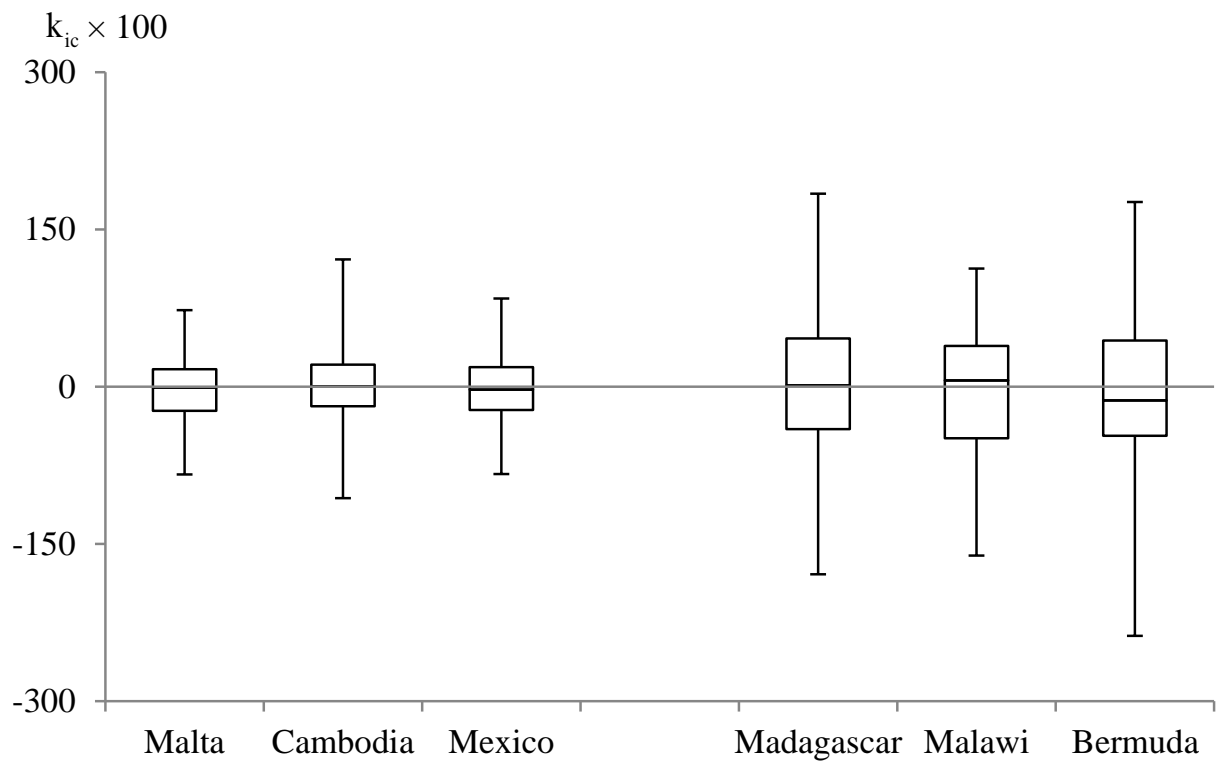

Note: Panel A contains box plots for the three commodities with the lowest interquartile range (IQR), and the three highest. The panel B box plots refer to the three countries with the lowest IQR and the three highest. See notes to Figure 6.1 for details of the "real relative price". 
Figure 6.3 Price Dispersion and Income, 175 countries in 2011

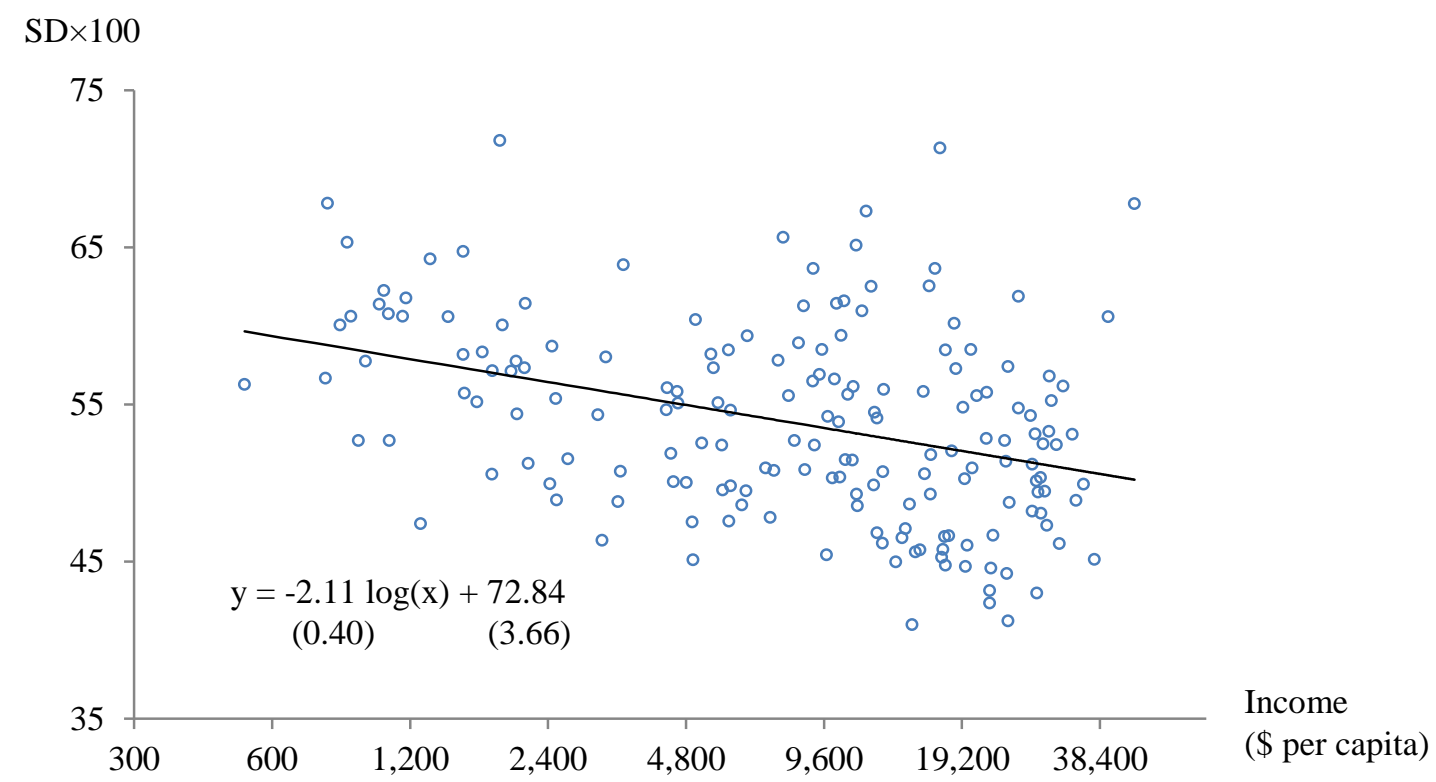

Note: The logarithmic real relative prices of the $n_{c}$ goods in country $c$ are $\mathrm{k}_{\mathrm{ic}}=\log \mathrm{p}_{\mathrm{ic}}-\log \mathrm{p}_{\mathrm{i}}^{*}-\log \mathrm{S}_{\mathrm{c}}, \mathrm{i}=1, \ldots, \mathrm{n}_{\mathrm{c}}$. Price dispersion in $\mathrm{c}$ is measured by the standard deviation (SD), $\sigma_{\mathrm{c}}=\sqrt{1 / \mathrm{n}_{\mathrm{c}} \cdot \sum_{\mathrm{i}=1}^{\mathrm{n}_{\mathrm{c}}}\left(\mathrm{k}_{\mathrm{ic}}-\mathrm{k}_{\mathrm{cc}}\right)^{2}}$, where $\mathrm{k}_{. \mathrm{c}}=1 / \mathrm{n}_{\mathrm{c}} \cdot \sum_{\mathrm{i}=1}^{\mathrm{n}_{\mathrm{c}}} \mathrm{k}_{\mathrm{ic}}$ is the country mean. 
Figure 7.1 Slope Coefficients, Cross-Country Regressions, 198 Food Items $\log \mathrm{p}_{\mathrm{ic}}=\alpha_{\mathrm{i}}+\beta_{\mathrm{i}} \log \mathrm{S}_{\mathrm{c}}+\varepsilon_{\mathrm{ic}}, \mathrm{c}=1, \ldots, \mathrm{C}_{\mathrm{i}}$ consuming countries; $\mathrm{i}=1, \ldots, 198$ food items

A. $\underline{\text { Smaller bins }}$

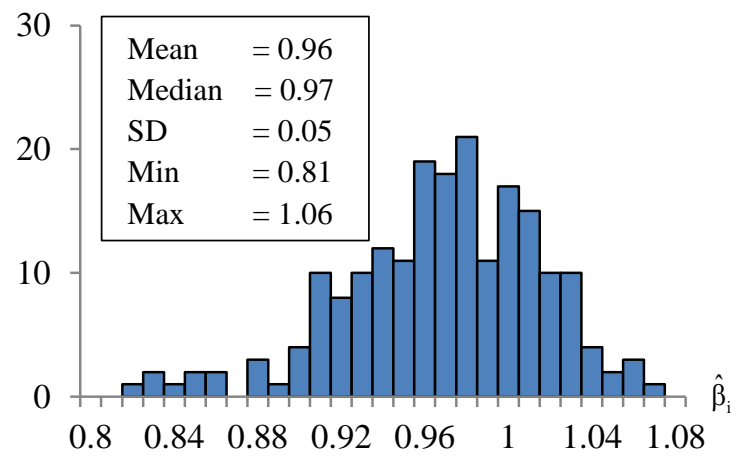

B. Larger bins

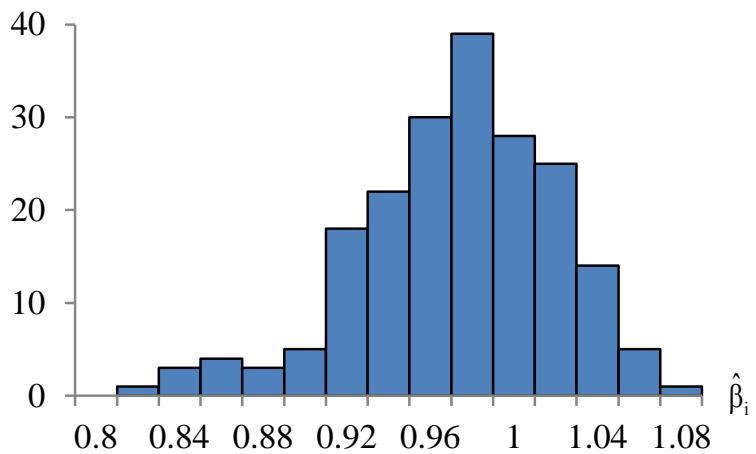

C. Cumulative Distributions

$\underline{\text { Slopes }}$

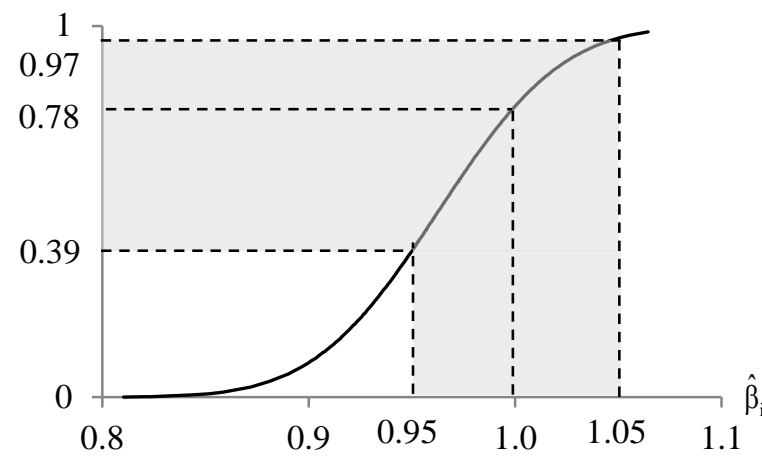

Absolute $\mathrm{t}$-values for $\mathrm{H}_{0}:{\beta^{\prime}}_{\mathrm{c}}=1$

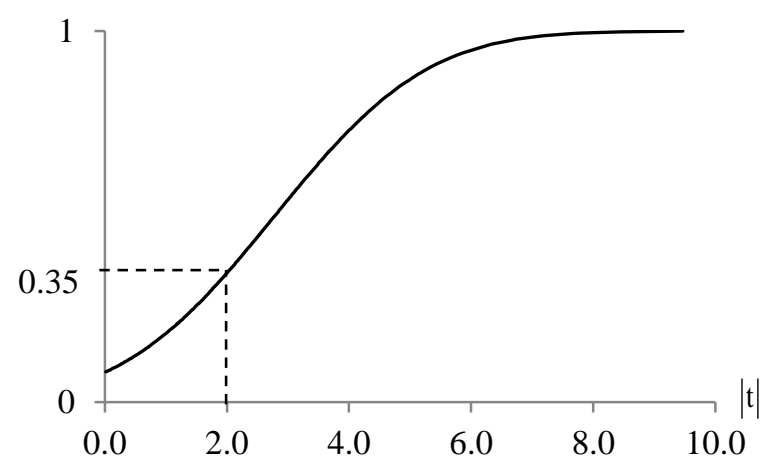

D. Food item

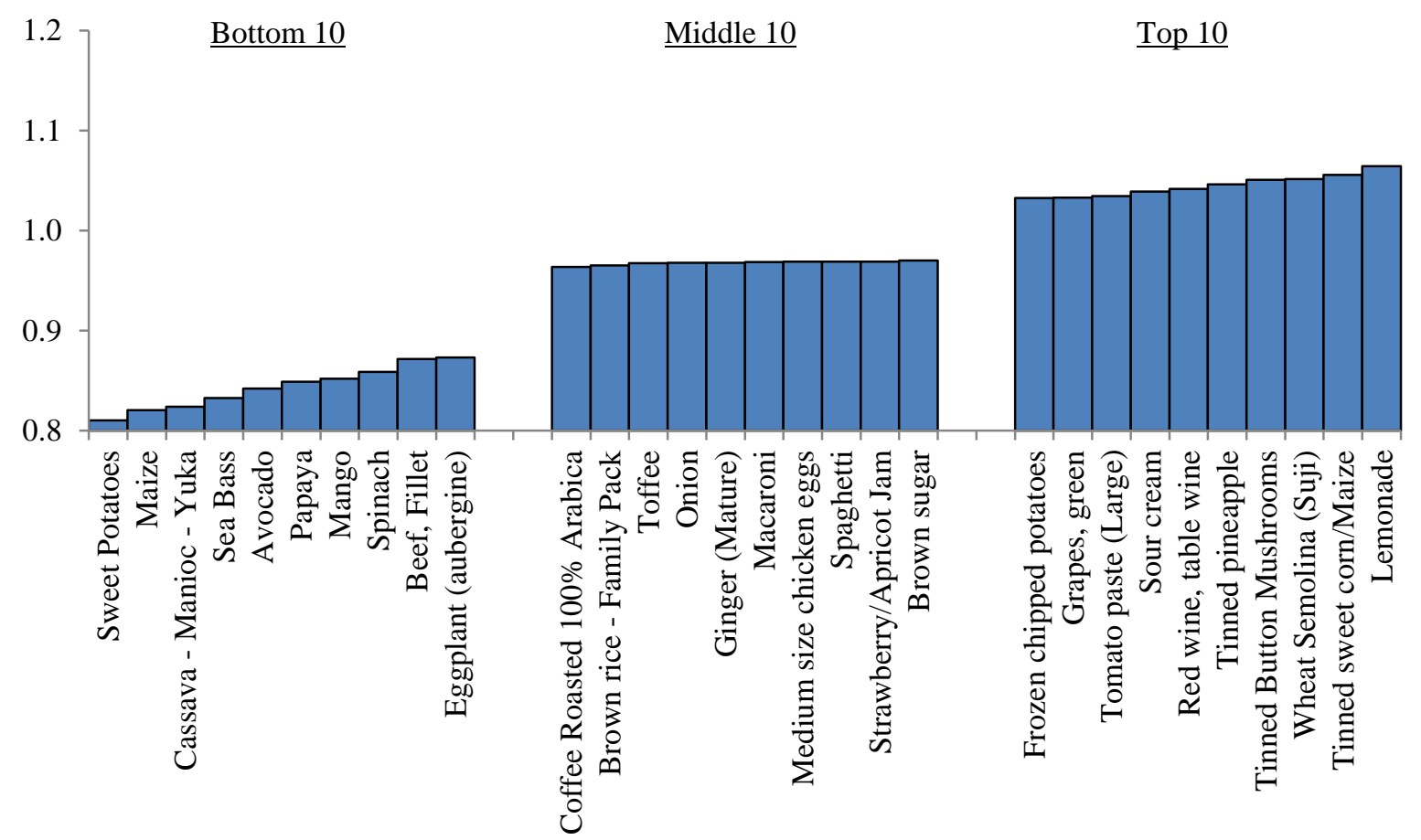


Figure 7.2 Slope Coefficients, Cross-Commodity Regressions, 175 countries $\log \mathrm{p}_{\mathrm{ic}}=\alpha_{\mathrm{c}}^{\prime}+\beta_{\mathrm{c}}^{\prime} \log \mathrm{p}_{\mathrm{i}}^{*}+\varepsilon_{\mathrm{ic}}^{\prime}, \mathrm{i}=1, \ldots, \mathrm{n}_{\mathrm{c}}$ food items consumed in $\mathrm{c} ; \mathrm{c}=1, \ldots, 175$ countries

A. $\underline{\text { Smaller bins }}$

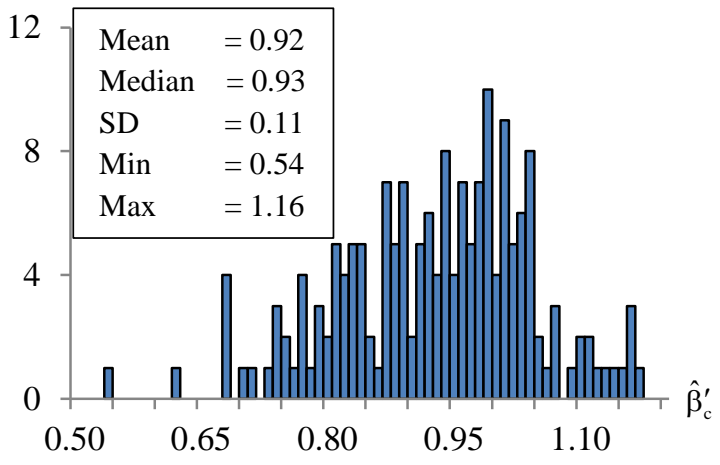

B. Larger bins

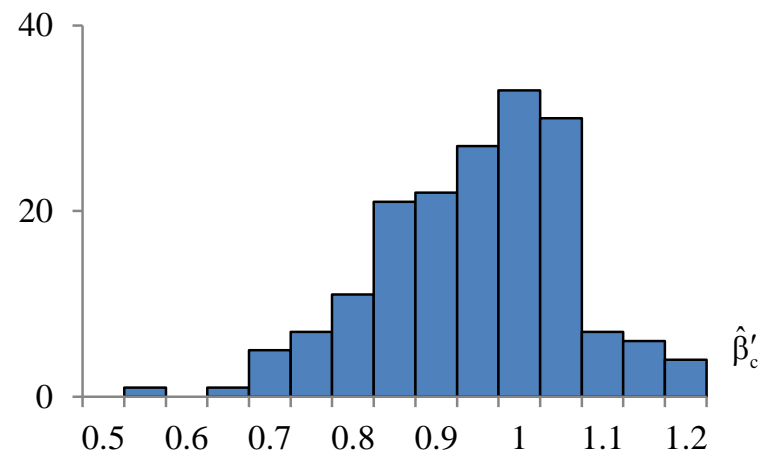

C. Cumulative Distributions

$\underline{\text { Slopes }}$

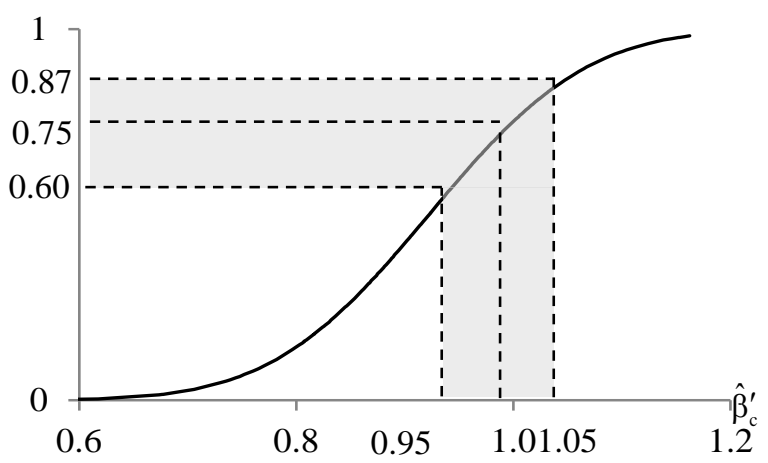

D. Country

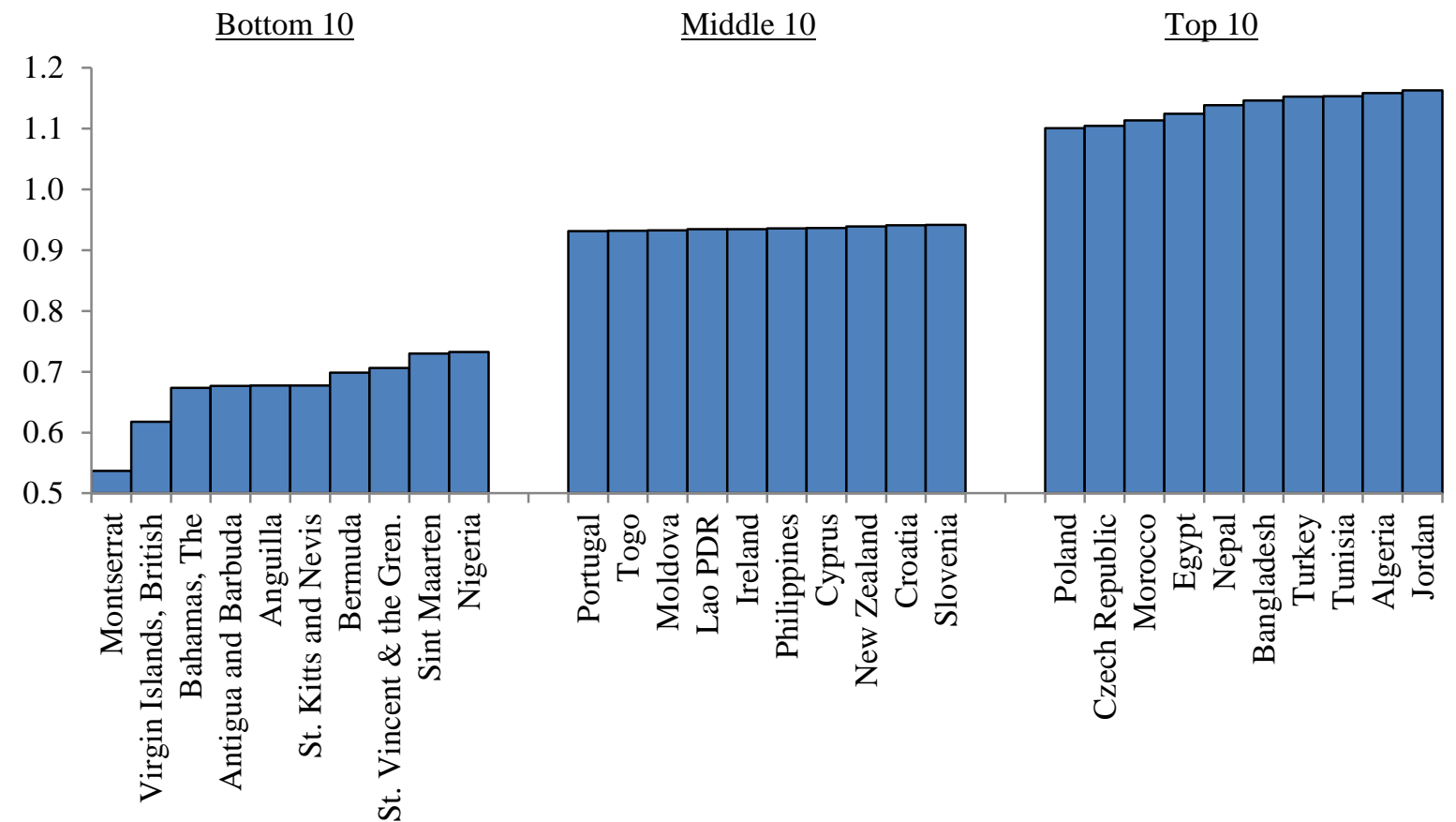


Figure 8.1 Real Relative Prices,

133 Food and Agriculture Commodities across 158 Countries, 1991 - 2013

Histogram

Cumulative distribution

A. All commodities and countries
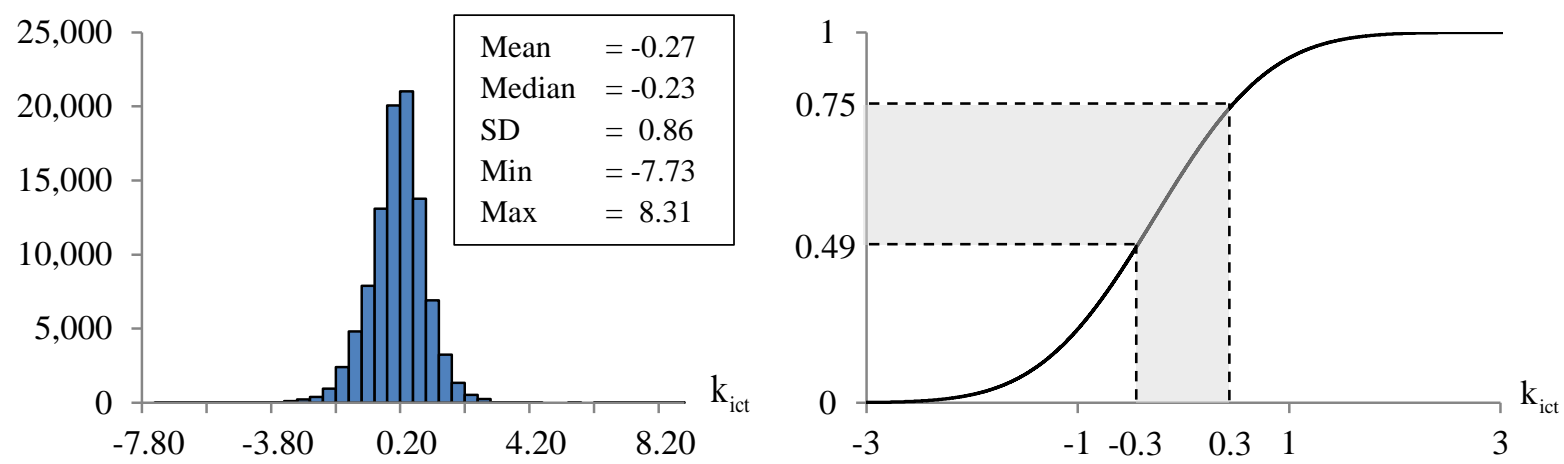

B. Country means
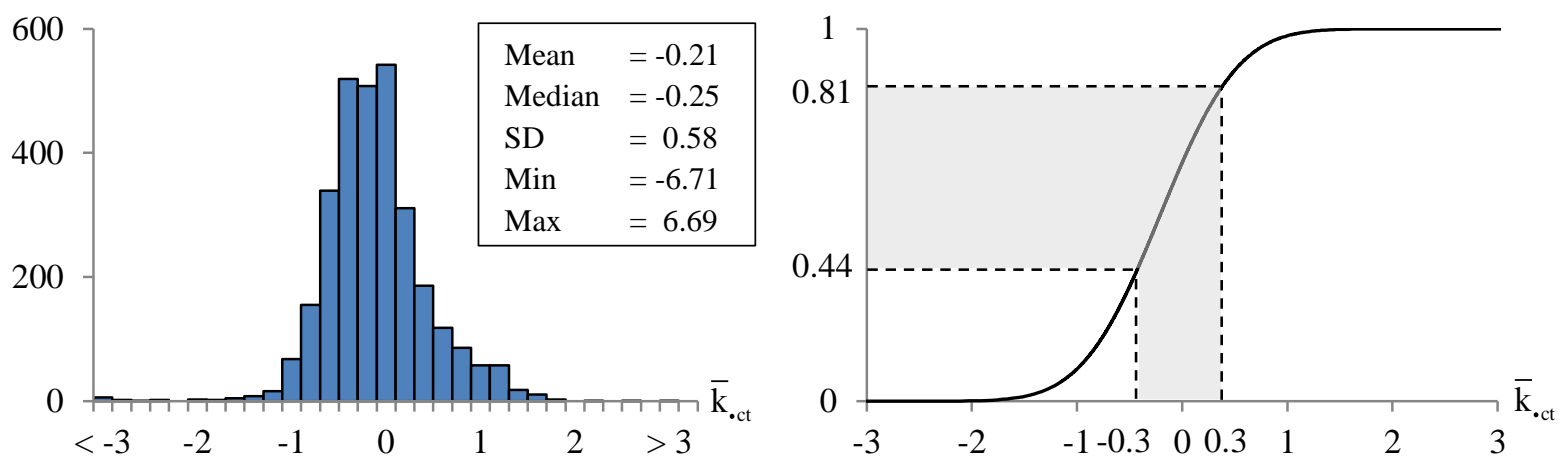

\section{Commodity means}

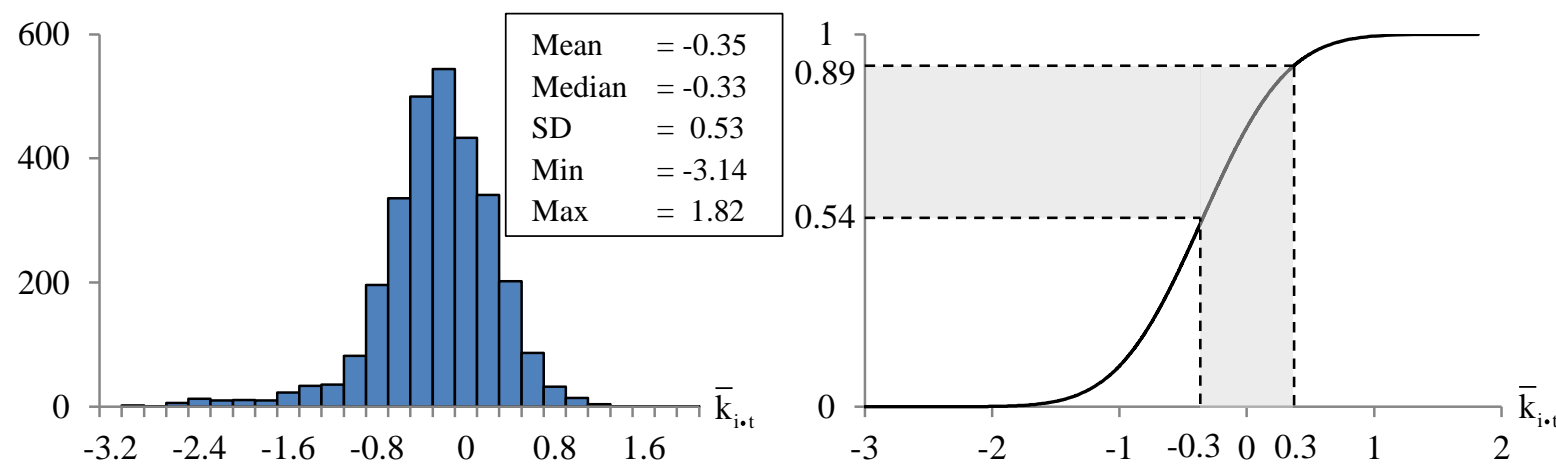

Notes:

The "real relative" price of commodity $i$ in country c in year t compares the domestic price $\left(p_{\text {ict }}\right)$ with the world price $\left(p_{i t}^{*}\right)$ after adjusting for differing currencies via the exchange rate $\left(S_{c t}\right)$. In logarithmic form, this is $\mathrm{k}_{\mathrm{ict}}=\log \mathrm{p}_{\mathrm{ict}}-\log \mathrm{p}_{\mathrm{it}}^{*}-\log \mathrm{S}_{\mathrm{ct}}$, which is 0 when prices coincide, and positive (negative) when the domestic price is above (below) the world price. Calculations are done using producer prices from the Food and Agriculture Organisation (FAO, online); see Appendix B for more details of the data. 
Figure 10.1 Summary of Unit Root Tests,

124 Food and Agriculture Items, 1991 - 2013

A. Frequency Distribution of $\mathrm{Z}^{*}$-stat

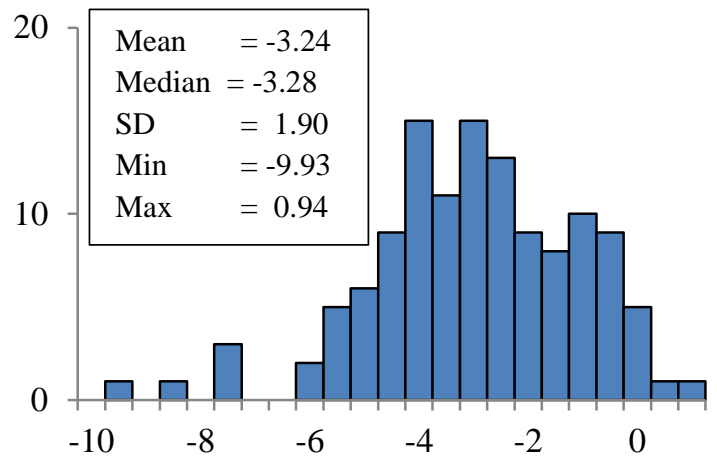

B. Cumulative Distribution

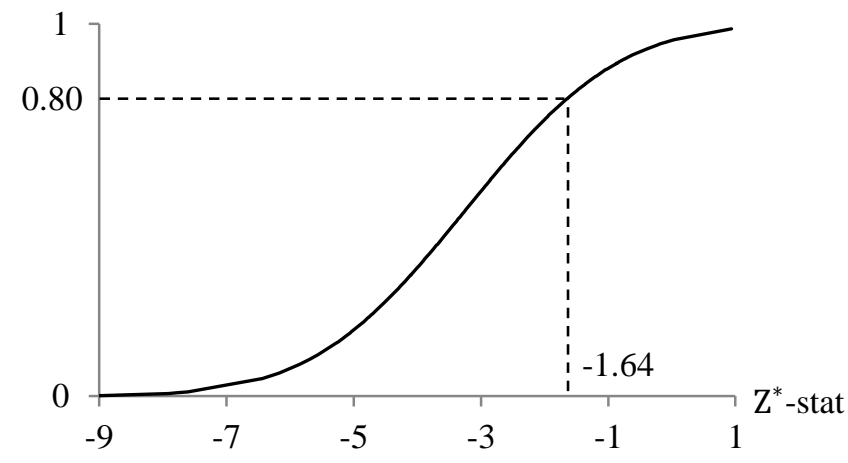

C. Food item

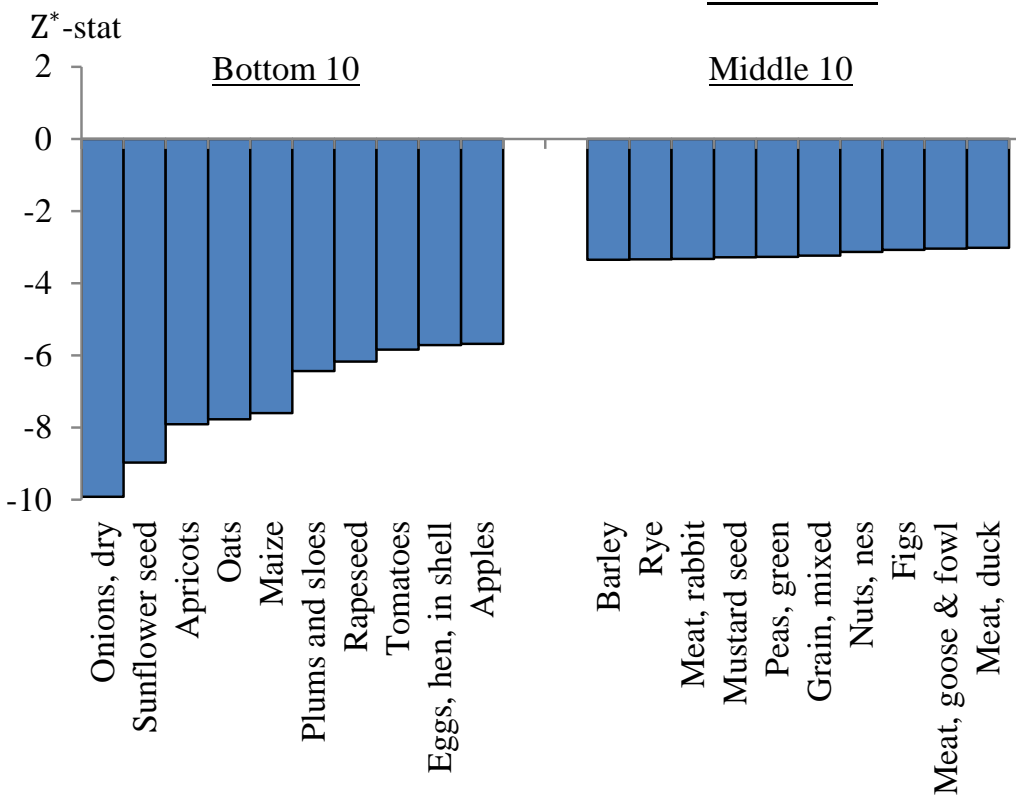

$\underline{\text { Top } 10}$

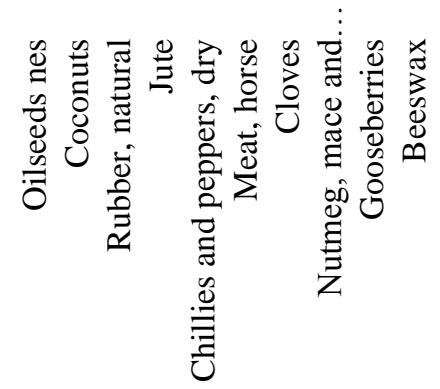

Note: The $\mathrm{Z}^{*}$-stat tests $\mathrm{H}_{0}: \beta_{\mathrm{c}}=0 \forall \mathrm{c}$ in $\Delta \mathrm{k}_{\mathrm{ict}}=\alpha_{\mathrm{c}}+\beta_{\mathrm{c}} \mathrm{k}_{\mathrm{ic}, \mathrm{t}-1}+\sum_{\mathrm{p}=1}^{\mathrm{m}_{\mathrm{c}}} \phi_{\mathrm{cp}} \Delta \mathrm{k}_{\mathrm{ic}, \mathrm{t}-\mathrm{p}}+\varepsilon_{\mathrm{ict}}$. See text for details. 


\section{APPENDIX}

\section{A. THE ICP DATA}

In this appendix, we provide an overview of the underlying data from the World Bank's International Comparison Program (ICP). Sections 2 to 4 draws upon the price and expenditure data at the so-called "basic heading level" from the ICP, whilst Sections 6 and 7 use the ICP's "product level" average price data. These are all from the end-user's point of view, that is, consumers.

\section{Basic Heading Level Data}

The 2011 round of ICP data contains disaggregated expenditures and prices of 155 basic headings for 182 countries. These are unpublished data supplied to us by the World Bank, listed in Table A.1. Total consumption is defined as the sum of the first 132 basic headings; this follows the ICP's definition of "Actual Household Consumption", which is the total value of the individual consumption expenditures of households, non-profit institutions serving households, and general government at purchasers' prices. Within the 132 basic headings, we consider the first 32 as food items.

We make two adjustments to the data. Firstly, we remove duplicate entries for three countries (Russia, Sudan and Egypt), each of which is a dual participant in the ICP. Next, Cuba and Bonaire do not have complete data and are omitted.

Second, we combine some commodities. Many West Asia countries have little to no PPP real expenditure per capita on pork due to religious reasons. We partially "solve" this by combining the "Pork" and "Lamb, mutton and goat" groups; so food now consists of 31 basic headings. To maintain internal consistency when we combine, expenditures (in both domestic currency units and in US dollars, that is, real expenditures) are summed over the subcomponents, whilst the purchasing power parity of the combination is the ratio of nominal to real expenditures. Using a minimum cut-off of $\$ 0.01$, the following 22 countries are omitted: Algeria, Angola, Bangladesh, Brunei Darussalam, Burundi, Egypt, Ethiopia, Iran, Kuwait, Lao PDR, Malawi, Maldives, Mauritania, Myanmar, Nicaragua, Pakistan, Palestinian Territory, Saudi Arabia, Sudan, Tanzania, Togo and Yemen. Our final sample thus contains 182 (the starting number of countries) -3 (duplicates) - 2 (Cuba and Bonaire) - 22 (small consumption $)=155$ countries, listed in Table 2.1 .

One limitation of the ICP data is that the 32 basic headings exclude food consumed away from home, which is important in some high-income countries. Another limitation is 
that expenditure data is only available down to the basic heading level, which we use as a proxy for product-level expenditures in the weights for the world prices in Section 6.

Product-Level Prices

Also available are average prices, but not expenditures, of 1,244 products disaggregated from the 155 basic headings; Table A.2 lists the food products. Over half of the initial sample of product $\times$ country observations are missing, reflecting: (i) too few outlets selling the product for its average price to be estimated with sufficient precision; or (ii) the costs of searching out a sufficient number of outlets considered to be too high.

As before, Russia, Sudan and Egypt are dual participants in the ICP, so we keep only the entry that contains more observations. Cuba and Bonaire are also omitted as they have incomplete data. Additionally, average prices are unavailable for Iran and Georgia. This leaves $182-2-3-2=175$ unique countries. Finally, 257 products were removed as they were represented in less than 30 countries. The final sample consists of $1,244-257=987$ products, 198 foods and 789 non-foods, in 175 countries. If no prices were missing, there would be $987 \times 175=172,725$ valid observations. But as 81,266 are missing, there are $172,725-81,266=91,459$ product $\times$ country observations remaining.

\section{B. THE FAO DATA}

Producer price data from the Food and Agriculture Organisation (FAO) are used in Sections 8 to 10 of the paper. Our sample is made from combining two data sets from the FAO (FAO, online): (i) Annual domestic producer prices on 208 food and agricultural items in 162 countries over the 24-year period 1991 - 2014. (ii) The export quantities and values of 387 items from a varying number of countries over the period $1986-2013$. These export data are used in calculating world prices.

In combining these datasets, we omit items with no observations, leaving 133 items, over 158 countries, from 1991 to 2013; this yields 97,274 commodity-country-year observations. These form the basis of the relative price calculations in Sections 8 and 9. For the panel unit root tests in Section 10, we further exclude items with less than two producing countries and less than a total of 30 country-year observations. This leaves 124 items, covering 158 countries, from 1991 to 2013 , with a total of 79,194 observations. Table B.1 (available on request) presents the matching scheme for FAO data. 
Table A.1 ICP Basic Headings

\begin{tabular}{|c|c|c|c|}
\hline No. & ICP Basic Heading & No. & ICP Basic Heading \\
\hline 1. & Rice & 63. & Medical Services \\
\hline 2. & Other cereals, flour and other products & 64. & Dental services \\
\hline 3. & Bread & 65. & Paramedical services \\
\hline 4. & Other bakery products & 66. & Hospital services \\
\hline 5. & Pasta products & 67. & Motor cars \\
\hline 6. & Beef and veal & 68. & Motor cycles \\
\hline 7. & Pork & 69. & Bicycles \\
\hline 8. & Lamb, mutton and goat & 70. & Animal drawn vehicles \\
\hline 9. & Poultry & 71. & Fuels and lubricants for personal transport equipment \\
\hline 10. & Other meats and meat preparations & 72. & Maintenance and repair of personal transport equipment \\
\hline 11. & Fresh, chilled or frozen fish and seafood & 73. & Other services in respect of personal transport equipment \\
\hline 12. & Preserved or processed fish and seafood & 74. & Passenger transport by railway \\
\hline 13. & Fresh milk & 75. & Passenger transport by road \\
\hline 14. & Preserved milk and other milk products & 76. & Passenger transport by air \\
\hline 15. & Cheese & 77. & Passenger transport by sea and inland waterway \\
\hline 16. & Eggs and egg-based products & 78. & Combined passenger transport \\
\hline 17. & Butter and margarine & 79. & Other purchased transport services \\
\hline 18. & Other edible oils and fats & 80. & Postal services \\
\hline 19. & Fresh or chilled fruit & 81. & Telephone and telefax equipment \\
\hline 20. & Frozen, preserved or processed fruit and fruit-based prod. & 82. & Telephone and telefax services \\
\hline 21. & Fresh or chilled vegetables other than potatoes & 83. & Audio-visual, photo.and information processing equipment \\
\hline 22. & Fresh or chilled potatoes & 84. & Recording media \\
\hline 23. & Frozen, presser. Or processed veg. \& veg.-based products & 85. & Repair of audio-visual, photo. And info. Processing equipment \\
\hline 24. & Sugar & 86. & Major durables for outdoor and indoor recreation \\
\hline 25. & Jams, marmalades and honey & 87. & Maint. \& repair of other major durables for recreation \& culture \\
\hline 26. & Confectionery, chocolate and ice cream & 88. & Other recreational items and equipment \\
\hline 27. & Food products nec & 89. & Garden and pets \\
\hline 28. & Coffee, tea and cocoa & 90. & Veterinary and other services for pets \\
\hline 29. & Mineral waters, soft drinks, fruit and vegetable juices & 91. & Recreational and sporting services \\
\hline 30. & Spirits & 92. & Cultural services \\
\hline 31. & Wine & 93. & Games of chance \\
\hline 32. & Beer & 94. & Newspapers, books and stationery \\
\hline 33. & Tobacco & 95. & Package holidays \\
\hline 34. & Narcotics & 96. & Education \\
\hline 35. & Clothing mats, articles of clothing \& clothing accessories & 97. & Catering services \\
\hline 36. & Garments & 98. & Accommodation services \\
\hline 37. & Cleaning, repair and hire of clothing & 99. & Hairdressing salons and personal grooming establishments \\
\hline 38. & Shoes and other footwear & 100. & Appliances, articles and products for personal care \\
\hline 39. & Repair and hire of footwear & 101. & Prostitution \\
\hline 40. & Actual and imputed rentals for housing & 102. & Jewellery, clocks and watches \\
\hline 41. & Maintenance and repair of the dwelling & 103. & Other personal effects \\
\hline 42. & Water supply & 104. & Social protection \\
\hline 43. & Miscellaneous services relating to the dwelling & 105. & Insurance \\
\hline 44. & Electricity & 106. & Financial Intermediation Services Indirectly Measured (FISIM) \\
\hline 45. & Gas & 107. & Other financial services \\
\hline 46. & Other fuels & 108. & Other services nec \\
\hline 47. & Furniture and furnishings & 109. & Final cons. Exp. Of resident households in the rest of the world \\
\hline 48. & Carpets and other floor coverings & 110. & Final cons. Exp.of non-resident households in the eco. Territory \\
\hline 49. & Repair of furniture, furnishings and floor coverings & 111. & Individual consumption expenditure by NPISHs \\
\hline 50. & Household textiles & 112. & Housing \\
\hline 51. & Major household appliances whether electric or not & 113. & Pharmaceutical products \\
\hline 52. & Small electric household appliances & 114. & Other medical products \\
\hline 53. & Repair of household appliances & 115. & Therapeutic appliances and equipment \\
\hline 54. & Glassware, tableware and household utensils & 116. & Out-patient medical services \\
\hline 55. & Major tools and equipment & 117. & Out-patient dental services \\
\hline 56. & Small tools and miscellaneous accessories & 118. & Out-patient paramedical services \\
\hline 57. & Non-durable household goods & 119. & Hospital services \\
\hline 58. & Domestic services & 120. & Compensation of employees \\
\hline 59. & Household services & 121. & Intermediate consumption \\
\hline 60. & Pharmaceutical products & 122. & Gross operating surplus \\
\hline 61. & Other medical products & 123. & Net taxes on production \\
\hline 62. & Therapeutic appliances and equipment & 124. & Receipts from sales \\
\hline
\end{tabular}


Table A.1 ICP Categories (continued)

\begin{tabular}{llll}
\hline \hline No. & \multicolumn{1}{c}{ ICP Basic Heading } & No. & \\
\hline 125. & Recreation and culture & 141. & Electrical and optical equipment \\
126. & Education benefits and reimbursements & 142. & Other manufactured goods nec \\
127. & Compensation of employees & 143. & Motor vehicles, trailers and semi-trailers \\
128. & Intermediate consumption & 144. & Other road transport \\
129. & Gross operating surplus & 145. & Other transport equipment \\
130. & Net taxes on production & 146. & Residential buildings \\
131. & Receipt from sales & 147. & Non-residential buildings \\
132. & Social protection & 148. & Civil engineering works \\
133. & Compensation of employees & 149. & Other products \\
134. & Intermediate consumption & 150. & Opening value of inventories \\
135. & Gross operating surplus & 151. & Closing value of inventories \\
136. & Net taxes on production & 152. & Acquisitions of valuables \\
137. & Receipts from sales & 153. & Disposals of valuables \\
138. & Fab. Metal products, except machinery \& equipment & 154. & Exports of goods and services \\
139. & General purpose machinery & 155. & Imports of goods and services \\
140. & Special purpose machinery & & \\
\hline Source & World Bank (unpublished) & & \\
\hline
\end{tabular}

Source: Worla punk (unpublised) 
Table A.2 Food Products

\begin{tabular}{|c|c|c|c|c|c|}
\hline $\begin{array}{l}\text { No. } \\
(1)\end{array}$ & $\begin{array}{c}\text { Product } \\
\text { (2) }\end{array}$ & $\begin{array}{l}\text { No. } \\
(3)\end{array}$ & $\begin{array}{c}\text { Product } \\
(4)\end{array}$ & $\begin{array}{c}\text { No. } \\
(5)\end{array}$ & $\begin{array}{c}\text { Product } \\
(6)\end{array}$ \\
\hline 1. & Long grain rice - Parboiled & 67. & Squid & 133. & Ginger (Mature) \\
\hline 2. & Long grain rice - Non-Parboiled & 68. & Red snapper & 134. & Garlic (White) \\
\hline 3. & Long grain rice - Family Pack & 69. & Sea Crab & 135. & Brown Potatoes \\
\hline 4. & Jasmine Rice & 70. & Tilapia & 136. & Sweet Potatoes \\
\hline 5. & Basmati Rice & 71. & Black Pomfret & 137. & Cassava - Manioc - Yuka \\
\hline 6. & White rice, $25 \%$ broken & 72. & Mullet & 138. & Dried white beans \\
\hline 7. & White rice, Medium Grain & 73. & Canned sardine with skin & 139. & Tinned white beans in tomato sauce \\
\hline 8. & Brown rice - Family Pack & 74. & Canned tuna without skin & 140. & Green Olives (with stones) \\
\hline 9. & Short-grained rice & 75. & Canned mackerel fillet in veg. oil & 141. & Potato chips \\
\hline 10. & Cornflakes [Specified brand] & 76. & Smoked salmon & 142. & Frozen chipped potatoes \\
\hline 11. & Wheat flour, not self-rising & 77. & Dried Shrimp & 143. & Tomato paste (Small) \\
\hline 12. & Wheat Semolina (Suji) & 78. & Milk, un-skimmed Pasteurized & 144. & Tomato paste (Large) \\
\hline 13. & Oats, rolled & 79. & Milk, un-skimmed UHT & 145. & Tinned green peas \\
\hline 14. & Maize Flour White & 80. & Milk, low-fat, Pasteurized & 146. & Tinned sweet corn/Maize \\
\hline 15. & Couscous & 81. & Milk, condensed & 147. & Lentils, Dry \\
\hline 16. & Baguette & 82. & Milk, powdered & 148. & Green/Mung Beans, dried \\
\hline 17. & White bread & 83. & Yoghurt, plain & 149. & Tinned Button Mushrooms \\
\hline 18. & Whole wheat bread & 84. & Sour cream & 150. & White sugar \\
\hline 19. & Roll & 85. & Cheese, Cheddar & 151. & Brown sugar \\
\hline 20. & Sliced White bread & 86. & Cream cheese & 152. & Strawberry/Apricot Jam \\
\hline 21. & Pita bread & 87. & Cheese, processed & 153. & Pineapple Jam \\
\hline 22. & Sandwich biscuits/cookies & 88. & Cheese, Camembert Type & 154. & Orange marmalade \\
\hline 23. & Chocolate cake (Individual serving) & 89. & Cheese, Gouda Type & 155. & Natural honey, Mixed blossoms \\
\hline 24. & Chocolate cake (Whole) & 90. & Bean Curd - Tofu & 156. & Chocolate bar \\
\hline 25. & All-butter croissant & 91. & Large size chicken eggs & 157. & Ice cream, Cornetto-type \\
\hline 26. & Butter biscuits & 92. & Medium size chicken eggs & 158. & Chewing gum \\
\hline 27. & Flavored biscuits/cookies sweet & 93. & Butter, unsalted & 159. & Fruit drops (Hard candies) \\
\hline 28. & Salted crackers & 94. & Salted Butter & 160. & Ice cream, packed \\
\hline 29. & Short pasta & 95. & Margarine, regular fat & 161. & Toffee \\
\hline 30. & Spaghetti & 96. & Sunflower oil & 162. & Mayonnaise \\
\hline 31. & Dried Noodles & 97. & Olive oil & 163. & Cooking salt \\
\hline 32. & Instant Noodles & 98. & Palm oil & 164. & Tomato ketchup \\
\hline 33. & Vermicelli (Angel Hair) & 99. & Soybean oil & 165. & Black Pepper, ground \\
\hline 34. & Macaroni & 100. & Peanut oil & 166. & Thin Soya Sauce \\
\hline 35. & Beef, Fillet & 101. & Vegetable oil & 167. & Curry Powder \\
\hline 36. & Beef, Rump steak & 102. & Apple, Red Delicious & 168. & Chicken Ext. (bouillon/stock cube) \\
\hline 37. & Beef, Center brisket & 103. & Banana, Standard & 169. & Baking powder \\
\hline 38. & Beef, for stew or curry & 104. & Grapes, green & 170. & Baby food \\
\hline 39. & Beef with bones & 105 . & Grapefruit & 171. & Chili sauce \\
\hline 40. & $100 \%$ Beef, minced & 106. & Orange & 172. & Chili powder \\
\hline 41. & Veal chops & 107. & Papaya & 173. & Baby cereals \\
\hline 42. & $\begin{array}{l}\text { Veal breast (non-refrigerated), with } \\
\text { bones }\end{array}$ & 108. & Pineapple & 174. & Cocoa Powder, Tin \\
\hline 43. & Pork, loin chop & 109. & Lemon & 175. & Instant coffee [Specified brand] \\
\hline 44. & Pork, fillet & 110. & Mango & 176. & Coffee Roasted $100 \%$ Arabica \\
\hline 45. & Pork, shoulder & 111. & Watermelon & 177. & Coffee Roasted $100 \%$ Robusta \\
\hline 46. & Pork, ribs & 112. & Apple, Typical Local Variety & 178. & Tea bags, black \\
\hline 47. & Lamb whole leg & 113. & Peach & 179. & Tea, green \\
\hline 48. & Lamb chops & 114. & Melon & 180. & Tea, black \\
\hline 49. & Mutton mixed cut & 115. & Tinned pineapple & 181. & Mineral water \\
\hline 50. & $\begin{array}{l}\text { Goat mixed cut/with bones (non- } \\
\text { refrigerated) }\end{array}$ & 116. & Dried almonds & 182. & Carb. S.Drink [Spec. brand] (Small) \\
\hline 51. & Whole chicken - Broiler & 117. & Roasted groundnuts/peanuts & 183. & Carb. S.Drink [Spec. brand] (Large) \\
\hline 52. & Whole chicken & 118. & Mixed Fruits in Syrup & 184. & Apple juice \\
\hline 53. & Chicken breast without skin & 119. & Dried dates & 185. & Orange juice \\
\hline 54. & Chicken legs & 120. & Cucumber & 186. & Lemonade \\
\hline 55. & Live chicken & 121. & Bell pepper & 187. & Vodka \\
\hline 56. & Chicken breast with skin and bones & 122. & Carrots & 188. & Whisky \\
\hline 57. & Pork ham, pressed & 123. & Onion & 189. & Gin [Specified Brand] \\
\hline 58. & Bacon, smoked & 124. & Maize & 190. & $\begin{array}{l}\text { Irish whiskey \& cream liquer [Spec. } \\
\text { brand] }\end{array}$ \\
\hline 59. & Beef liver & 125 . & Round tomato, loose & 191. & Superior Light/White Rum \\
\hline 60. & Corned beef & 126. & Green cabbage & 192. & Red wine, table wine \\
\hline 61. & Canned chicken & 127. & Lettuce & 193. & Red wine, Bordeaux Supérieur \\
\hline 62. & Carp & 128. & Avocado & 194. & White wine, table wine \\
\hline 63. & Mackerel, un-cleaned & 129. & Eggplant (aubergine) & 195. & Sparkling wine \\
\hline 64. & Sea Bass & 130. & Cauliflower & 196. & Domestic Canned Beer \\
\hline 65. & Whole Shrimps & 131. & Spinach & 197. & Domestic Beer Bottle \\
\hline 66. & Shrimps & 132. & Chilies (Long) & 198. & Beer [Specified brand] \\
\hline
\end{tabular}

Note: Listed in this table are the 198 food products out of the total 987 products

Source: World Bank (unpublished). 
Editor, UWA Economics Discussion Papers:

Sam Hak Kan Tang

University of Western Australia

35 Sterling Hwy

Crawley WA 6009

Australia

Email: ecoadmin@biz.uwa.edu.au

The Economics Discussion Papers are available at:

1980 - 2002: http://ecompapers.biz.uwa.edu.au/paper/PDF\%20of\%20Discussion\%20Papers/

Since 2001: $\quad$ http://ideas.repec.org/s/uwa/wpaper1.html

Since 2004: $\quad$ http://www.business.uwa.edu.au/school/disciplines/economics

\begin{tabular}{|c|c|c|}
\hline \multicolumn{3}{|c|}{ ECONOMICS DISCUSSION PAPERS - 2016} \\
\hline $\begin{array}{l}\text { DP } \\
\text { NUMBER }\end{array}$ & AUTHORS & TITLE \\
\hline 16.01 & $\mathrm{Xu}, \mathrm{R} ., \mathrm{Wu}, \mathrm{Y}$. and Luan, J. & $\begin{array}{l}\text { ANALYSIS OF FARMERS' WILLINGNESS TO ADOPT } \\
\text { GENETICALLY MODIFIED INSECT-RESISTANT RICE IN } \\
\text { CHINA }\end{array}$ \\
\hline 16.02 & $\begin{array}{l}\text { Lia, Y., Fan, J., Zhao, D., Wu, Y. and } \\
\text { Li, J. }\end{array}$ & $\begin{array}{l}\text { TIERED GASOLINE PRICING: A PERSONAL CARBON } \\
\text { TRADING PERSPECTIVE }\end{array}$ \\
\hline 16.03 & Clements, K.W., Lan, Y. and Si, J. & UNCERTAINTY IN CURRENCY MISPRICING \\
\hline 16.04 & Parsons, C. and Vézina, P.L. & $\begin{array}{l}\text { MIGRANT NETWORKS AND TRADE:THE VIETNAMESE } \\
\text { BOAT PEOPLE AS A NATURAL EXPERIMENT }\end{array}$ \\
\hline 16.05 & Chang, S., Connelly, R. and Ma, P. & $\begin{array}{l}\text { WHAT WILL YOU DO IF I SAY ‘I DO’?: THE EFFECT OF } \\
\text { THE SEX RATIO ON TIME USE WITHIN TAIWANESE } \\
\text { MARRIED COUPLES }\end{array}$ \\
\hline 16.06 & $\mathrm{Yu}, \mathrm{F}$. and $\mathrm{Wu}, \mathrm{Y}$. & $\begin{array}{l}\text { BIASES IN PATENT EXAMINATION AND FIRMS' } \\
\text { RESPONSES: EVIDENCE FROM THE } \\
\text { PHARMACEUTICAL INDUSTRY }\end{array}$ \\
\hline 16.07 & $\begin{array}{l}\text { Fan, J., Li, J., Wu, Y., Wang, S. and } \\
\text { Zhao, D. }\end{array}$ & $\begin{array}{l}\text { THE EFFECTS OF ALLOWANCE PRICE ON ENERGY } \\
\text { DEMAND UNDER A PERSONAL CARBON TRADING } \\
\text { SCHEME }\end{array}$ \\
\hline 16.08 & Golley, J., Tyers, R. and Zhou, Y. & $\begin{array}{l}\text { CONTRACTIONS IN CHINESE FERTILITY AND } \\
\text { SAVINGS: LONG RUN DOMESTIC AND GLOBAL } \\
\text { IMPLICATIONS }\end{array}$ \\
\hline 16.09 & McGrath, G. and Neill, K. & $\begin{array}{l}\text { FOREIGN AND DOMESTIC OWNERSHIP IN WESTERN } \\
\text { AUSTRALIA'S GAS MARKET }\end{array}$ \\
\hline 16.10 & Clements, K.W. and Si, J. & SIMPLIFYING THE BIG MAC INDEX \\
\hline 16.11 & Priyati, R.Y. and Tyers, R. & $\begin{array}{l}\text { PRICE RELATIONSHIPS IN VEGETABLE OIL AND } \\
\text { ENERGY MARKETS }\end{array}$ \\
\hline 16.12 & Wu, J., Wu, Y. and Wang, B. & $\begin{array}{l}\text { THE GREENNESS OF CHINESE CITIES: CARBON } \\
\text { DIOXIDE EMISSION AND ITS DETERMINANTS }\end{array}$ \\
\hline 16.13 & $\begin{array}{l}\text { Arslan, C., Dumont, J.C., Kone, Z., } \\
\text { Özden, Ç., Parsons, C. and } \\
\text { Xenogiani, T. }\end{array}$ & $\begin{array}{l}\text { INTERNATIONAL MIGRATION TO THE OECD IN THE } \\
\text { TWENTY-FIRST CENTURY }\end{array}$ \\
\hline 16.14 & Tomioka, K. and Tyers, R. & $\begin{array}{l}\text { HAS FOREIGN GROWTH CONTRIBUTED TO } \\
\text { STAGNATION AND INEQUALITY IN JAPAN? }\end{array}$ \\
\hline 16.15 & Donovan, J. and Hartley, P. & $\begin{array}{l}\text { RIDING THE IRON ORE CYCLE: ACTIONS OF } \\
\text { AUSTRALIA'S MAJOR PRODUCERS }\end{array}$ \\
\hline 16.16 & Czaika, M. and Parsons, C. & $\begin{array}{l}\text { HIGH-SKILLED MIGRATION IN TIMES OF GLOBAL } \\
\text { ECONOMIC CRISIS }\end{array}$ \\
\hline
\end{tabular}




\begin{tabular}{|l|l|l|}
\hline 16.17 & Lefroy, T., Key, J. and Kingwell, R. & $\begin{array}{l}\text { A LONGITUDINAL EXAMINATION OF BROADACRE } \\
\text { FARM SIZE AND PERFORMANCE IN WESTERN } \\
\text { AUSTRALIA }\end{array}$ \\
\hline 16.18 & Arthmar, R. and McLure, M. & $\begin{array}{l}\text { SRAFFA, MYRDAL AND THE 1961 SÖDERSTRÖM GOLD } \\
\text { MEDAL }\end{array}$ \\
\hline 19.19 & Azwar, P. and Tyers, R. & $\begin{array}{l}\text { POST-GFC EXTERNAL SHOCKS AND INDONESIAN } \\
\text { ECONOMIC PERFORMANCE }\end{array}$ \\
\hline 19.20 & Chen, A. and Groenewold, N. & $\begin{array}{l}\text { OUTPUT SHOCKS IN CHINA: DO THE DISTRIBUTIONAL } \\
\text { EFFECTS DEPEND ON THE REGIONAL SOURCE? }\end{array}$ \\
\hline 19.21 & Wu, Y., Zhu, X. and Groenewold, N. & $\begin{array}{l}\text { THE DETERMINANTS AND EFFECTIVENESS OF } \\
\text { INDUSTRIAL POLICY IN CHINA: A STUDY BASED ON } \\
\text { FIVE-YEAR PLANS }\end{array}$ \\
\hline 16.22 & Liu, H. & $\begin{array}{l}\text { THE INCOME AND PRICE SENSITIVITY OF DIETS } \\
\text { GLOBALLY }\end{array}$ \\
\hline 16.23 & Asano, A., Neill, K. and Yamazaki, S. & $\begin{array}{l}\text { DECOMPOSING FISHING EFFORT: MODELLING THE } \\
\text { SOURCES OF INEFFICIENCY IN A LIMITED-ENTRY } \\
\text { FISHERY }\end{array}$ \\
\hline 16.24 & Golley, J., Tyers, R. and Zhou, Y. & $\begin{array}{l}\text { FERTILITY AND SAVINGS CONTRACTIONS IN CHINA: } \\
\text { LONG-RUN GLOBAL IMPLICATIONS }\end{array}$ \\
\hline 16.25 & Taylor, G., Tyers, R. & $\begin{array}{l}\text { Secular Stagnation: Determinants and Consequences for } \\
\text { Australia }\end{array}$ \\
\hline
\end{tabular}

\begin{tabular}{|l|l|l|}
\hline \multicolumn{2}{|c|}{ ECONOMICS DISCUSSION PAPERS - 2017 } \\
\hline $\begin{array}{c}|c| \\
\text { DP } \\
\text { NUMBER }\end{array}$ & \multicolumn{1}{|c|}{ AUTHORS } & \multicolumn{1}{c|}{ TITLE } \\
\hline 17.01 & Tyers, R. and Zhou, Y. & $\begin{array}{l}\text { AUTOMATION AND INEQUALITY WITH TAXES AND } \\
\text { TRANSFERS }\end{array}$ \\
\hline 17.02 & Ye, L. and Robertson, P. & $\begin{array}{l}\text { HITTING THE GREAT WALL: RURAL-URBAN } \\
\text { MIGRATION AND CHINA'S GROWTH SLOWDOWN }\end{array}$ \\
\hline 17.03 & Ye, L. and Robertson, P. & $\begin{array}{l}\text { MIGRATION AND GROWTH IN CHINA: A SCEPTICAL } \\
\text { ASSESSMENT OF THE EVIDENCE }\end{array}$ \\
\hline 17.04 & Clements, K. Si, J. and Vo, L. & $\begin{array}{l}\text { FOOD AND AGRICULTURAL PRICES ACROSS } \\
\text { COUNTRIES AND THE LAW OF ONE PRICE }\end{array}$ \\
\hline 17.05 & $\begin{array}{l}\text { Chen, M., Clements, K., Gao, G. and } \\
\text { Si, J. }\end{array}$ & $\begin{array}{l}\text { THREE FACTS ABOUT WORLD METAL PRICES } \\
\text { Cornes, R., Fiorini, L. and }\end{array}$ \\
\hline 17.06 & Maldonado, W. & $\begin{array}{l}\text { EXPECTATIONAL STABILITY IN AGGREGATIVE } \\
\text { GAMES }\end{array}$ \\
\hline 17.07 & $\begin{array}{l}\text { THE COST OF DISPLACING FOSSIL FUELS: SOME } \\
\text { EVIDENCE FROM TEXAS }\end{array}$ \\
\hline 17.08 & Shehabi, M. R. & $\begin{array}{l}\text { GSSESSING KUWAITI ENERGY PRICINING REFORMS } \\
\text { INTERACTION OR UNILATERAL GAINS? }\end{array}$ \\
\hline 17.09 & Perdana, S. and Tyers, R. & \\
\hline
\end{tabular}

